University of Louisville

ThinkIR: The University of Louisville's Institutional Repository

$12-2012$

\title{
Ready child, ready school : educator perceptions of child and school success indicators and ready school practices.
}

Annette W. Bridges 1953-

University of Louisville

Follow this and additional works at: https://ir.library.louisville.edu/etd

Part of the Educational Leadership Commons

\section{Recommended Citation}

Bridges, Annette W. 1953-, "Ready child, ready school : educator perceptions of child and school success indicators and ready school practices." (2012). Electronic Theses and Dissertations. Paper 1725.

https://doi.org/10.18297/etd/1725

This Doctoral Dissertation is brought to you for free and open access by ThinkIR: The University of Louisville's Institutional Repository. It has been accepted for inclusion in Electronic Theses and Dissertations by an authorized administrator of ThinkIR: The University of Louisville's Institutional Repository. This title appears here courtesy of the author, who has retained all other copyrights. For more information, please contact thinkir@louisville.edu. 


\title{
READY CHILD, READY SCHOOL: EDUCATOR PERCEPTIONS OF CHILD AND SCHOOL SUCCESS INDICATORS AND READY SCHOOL PRACTICES
}

\author{
By \\ Annette W. Bridges \\ B.S., Kentucky State University, 1975 \\ M.A.T., Spalding University, 1989

\begin{abstract}
A Dissertation
Submitted to the Faculty of the

College of Education and Human Development

in Partial Fulfillment of the Requirements

for the Degree of
\end{abstract}

\begin{abstract}
Doctor of Education
Department of Leadership, Foundations, and Human Resource Education University of Louisville

Louisville, Kentucky
\end{abstract}

December 2014 



\title{
READY CHILD, READY SCHOOL: EDUCATOR PERCEPTIONS OF CHILD AND SCHOOL SUCCESS INDICATORS AND READY SCHOOL PRACTICES
}

\author{
By
}

Annette W. Bridges

B.S., Kentucky State University, 1975

M.A.T., Spalding University, 1989

A Dissertation Approved on

November 14, 2014

By the following Dissertation Committee:

Dr. Melissa Evans-Andris

Dissertation Chair

Dr. Bradley Carpenter

Dr. Thomas Tretter

Dr. Gaetane Jean-Marie 


\section{DEDICATION}

This dissertation is dedicated to my husband

\section{Dwain Bridges}

and

a host of family and friends

who believed in me and encouraged me through this journey. 


\section{ACKNOWLEDGEMENTS}

First and foremost, I thank God for His purpose and will in my life. I would also like to thank my committee chair, Dr. Melissa Evans-Andris, for her wisdom in guiding me through the work. Dr. Tom Tretter was so patient with me and Kelly Ising was so kind when I asked her all sorts of questions, all of the time, and she always responded.

I am grateful to my pastor, Dr. T. Vaughn Walker, and to my friends, Dr. Cheryl Walker, Dr. Felicia Cumings Smith, and Lynda Conley, for their prayerful support. Alexis Williams calmed me when I panicked about tables. She is such a good teacher of technology. I would also like to acknowledge Peggy Washington and Charlesetta Miller; they always checked my progress and encouraged me to keep moving forward.

My family is so proud, including my children Jasmine and Damon and my siblings Brenda, Petey, Teresa, Keith, and Sonja. They have celebrated this moment from the very beginning of my journey. I serve as an example to my granddaughter, Kenniah, who will achieve at high levels as well! Although sometimes I didn't want to be reminded, I am so grateful for my husband, Dwain, who reminded me about the goals I had set to complete my dissertation. 


\title{
ABSTRACT \\ READY CHILD, READY SCHOOL: EDUCATOR PERCEPTIONS OF CHILD AND SCHOOL SUCCESS INDICATORS AND READY SCHOOL PRACTICES
}

\author{
Annette W. Bridges \\ December 18, 2014
}

In this study, the researcher considered educator perceptions of child readiness for school and school readiness for children conceptualized within the central constructs of the ready child and the ready school. The skills and abilities that children bring to the school are equally as important as the services and supports that the school brings to the child.

The researcher's intention in conducting this study was to investigate whether the differences existed in perceptions about ready child and ready school indicators and the implementation of ready school practices between educators working in successful schools and educators working in less successful schools. A nonexperimental, quantitative design was employed with cross-sectional data analysis of educator perceptions collected through a survey. The analytical procedures included correlational analyses and nonparametric statistical tests.

The sample consisted of 185 Kentucky educators who included 43 principals, 82 Kindergarten teachers, and 60 preschool teachers. The selection was intentional to ensure that the educators represented schools with scores above the state average (ASA) and schools with scores below the state average (BSA) on the 2011-2012 Kentucky Performance Rating for Educational Progress (K-PREP). The researcher found significant 
differences between the ASA and BSA educator (a) rankings of ready child indicators of health and physical well-being and approaches to learning; (b) rankings of the ready school indicator transition; and (c) rating of the teacher ready school practices. The findings suggest that school leaders, including staff, should consider examining their perceptions of the ready child and ready school, and the implementation of ready school practices to ensure that every child who enters Kindergarten has optimal learning opportunities for successful school experiences. 


\section{TABLE OF CONTENTS}

PAGE

ACKNOWLEDGEMENTS .......................................................................... iv

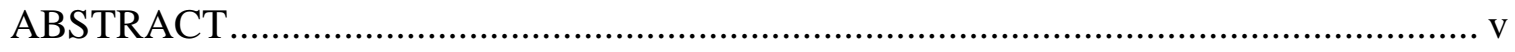

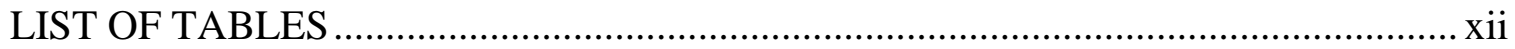

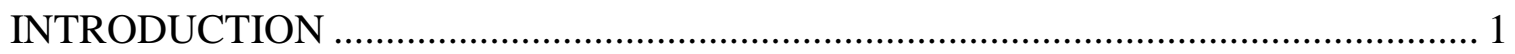

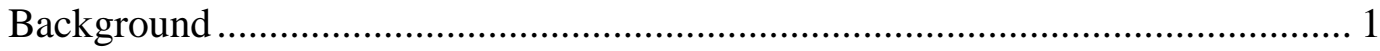

Historical Perspective ................................................................................. 3

Child and School Readiness in Kentucky .................................................... 7

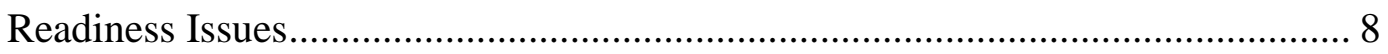

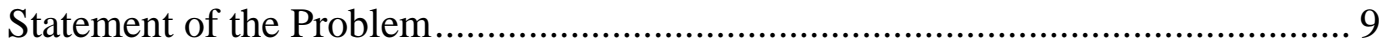

Purpose

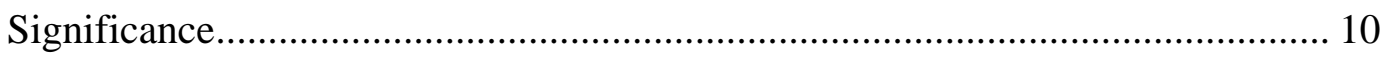

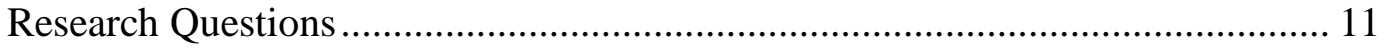

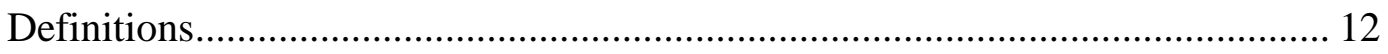

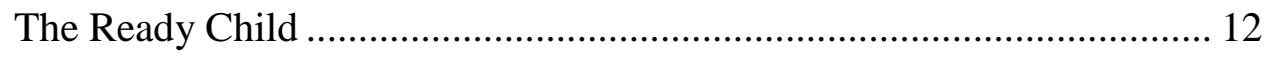

The Ready School .................................................................. 12

Successful Schools (for this study) ................................................ 13

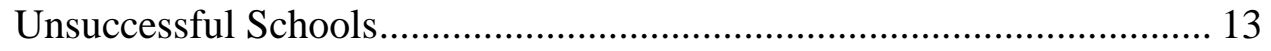

Kentucky's High Poverty Schools ................................................... 13

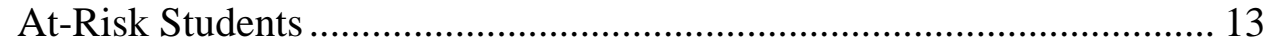

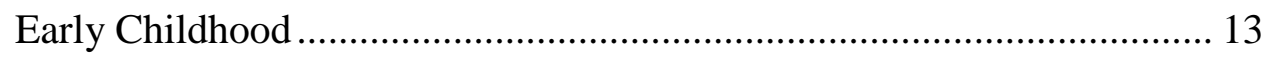

Head Start Program ..................................................................... 14

Effective Schools ....................................................................... 14 
High Performing Schools...................................................................... 14

2011 Race to the Top Early Learning Challenge Fund.............................. 15

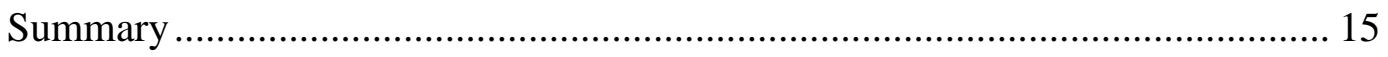

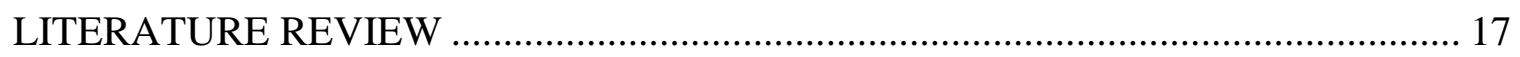

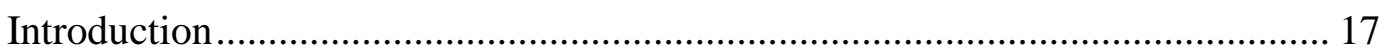

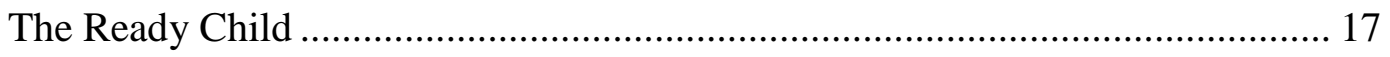

Foundation of the Ready Child Concept................................................... 17

Definition of the Ready Child................................................................... 20

Researcher's Operational Definition of the Ready Child ......................... 22

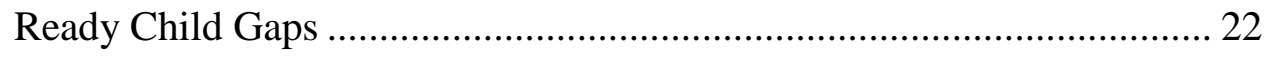

Ready Child Indicators from the Literature and Research........................ 24

Ready Child Indicators for the Study ..................................................... 27

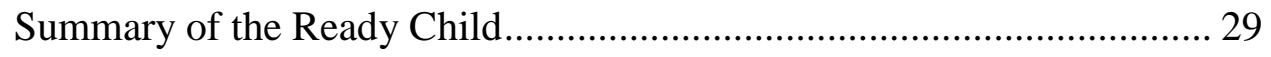

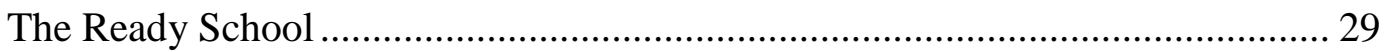

Foundation of the Ready School Concept ………………………............ 29

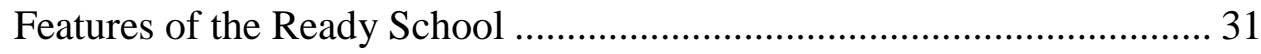

Definition of the Ready School.............................................................. 32

Researcher's Operational Definition of the Ready School ........................ 35

Ready School Indicators for the Study …………………......................... 35

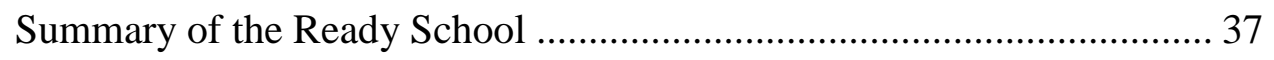

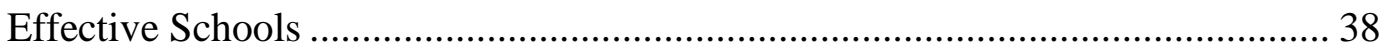

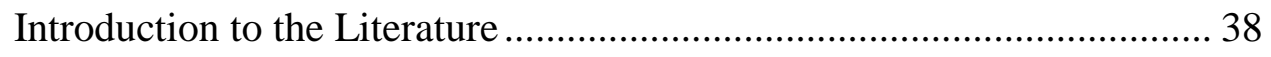

Characteristics of Effective Schools ......................................................... 40

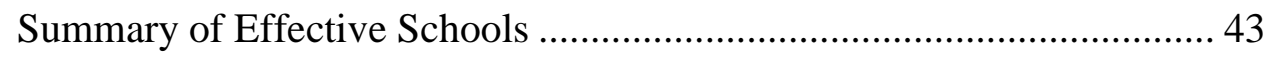




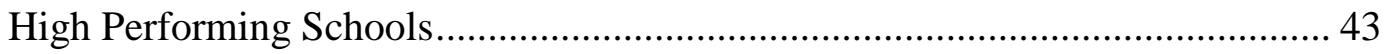

Introduction to the Literature ................................................................. 43

Key Features of High Performing Schools .............................................. 44

Summary of High Performing Schools ..................................................... 50

Conceptual Framework of the Study ................................................................ 51

Research Questions and Justification........................................................... 52

Why Is It Important to Get Answers to These Questions? ........................ 53

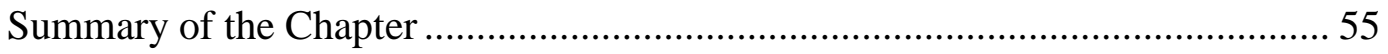

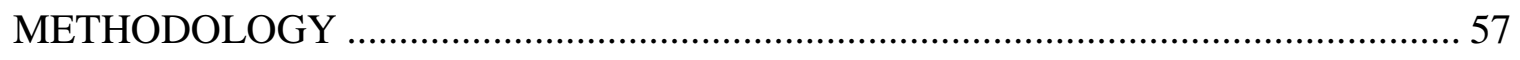

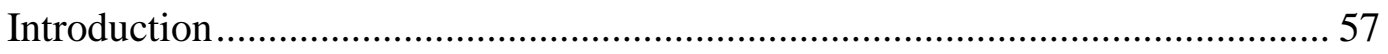

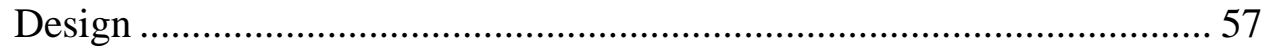

Research Ethics and Institutional Review Board Process.......................... 58

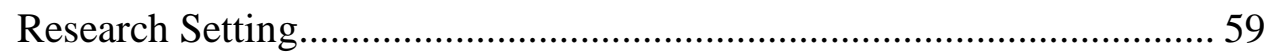

Sample

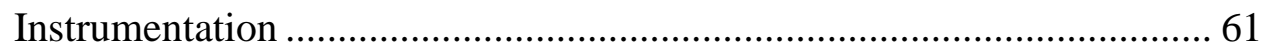

Development of the Ready Child, Ready School Survey .......................... 62

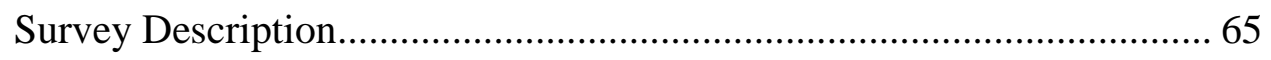

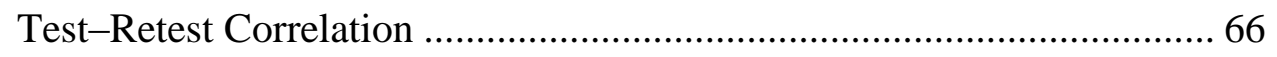

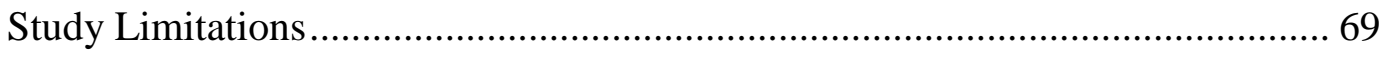

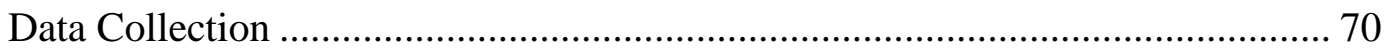

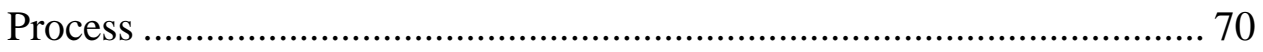

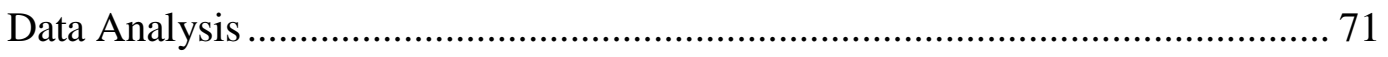

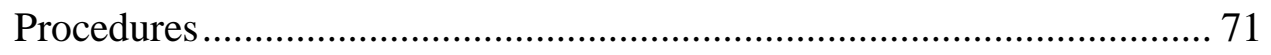

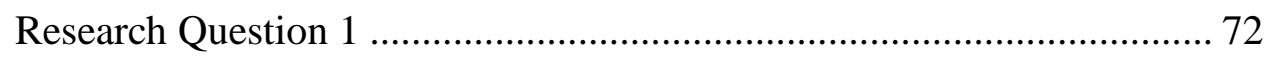


Research Question 3 ................................................................. 73

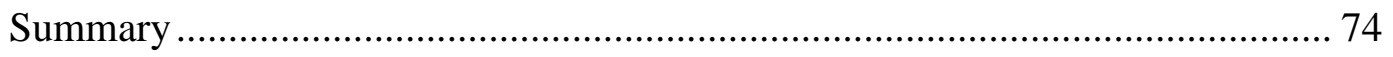

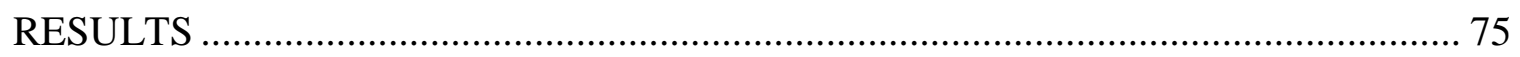

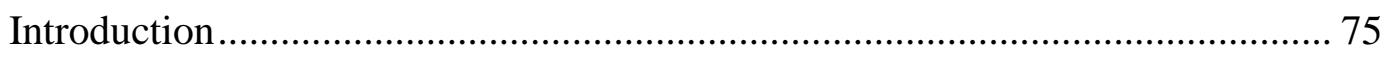

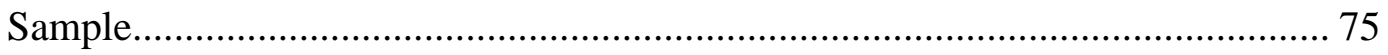

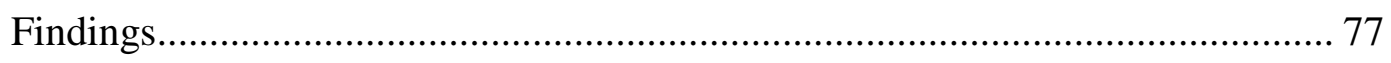

Research Question 1: Ready Child Indicator Rankings........................ 77

Research Question 2: Ready School Indicator Rankings ..................... 81

Ready Child, Ready School Open-Ended Questions ........................... 82

Research Question 3 .............................................................. 84

Combined Role Groups............................................................. 90

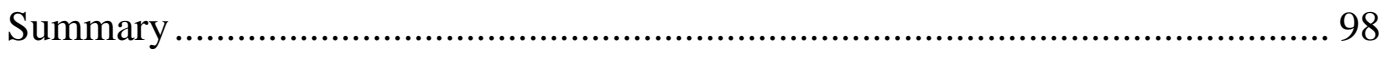

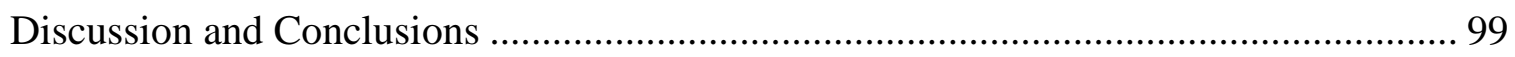

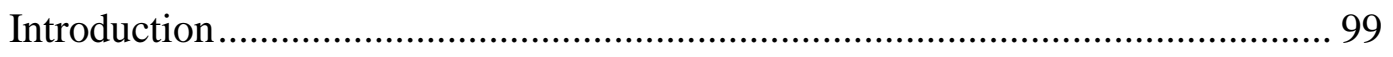

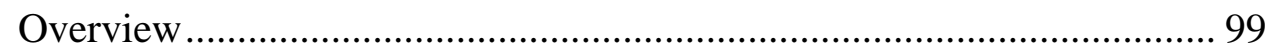

Summary of Major Findings ................................................................... 100

Interpretation of Results and Findings ................................................. 100

Demographic Findings .......................................................... 100

Results and Findings from Research Question 1: Ready Child

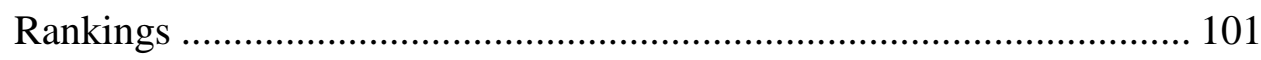

Results and Findings from Research Question 2: Ready School

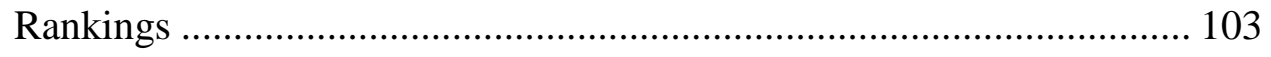


Results and Findings: Ready Child, Ready School Open-Ended

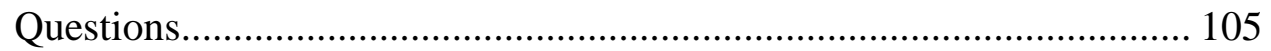

Results and Findings from Research Question 3 .............................. 106

Correlations Between Ready School Rankings and Ready School

Practices ............................................................................. 108

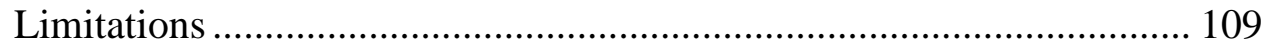

Implications for Policy and Practice .............................................. 109

Future Research .................................................................... 111

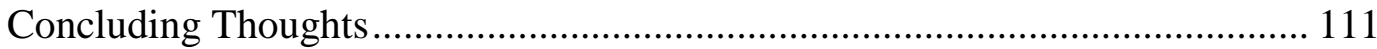

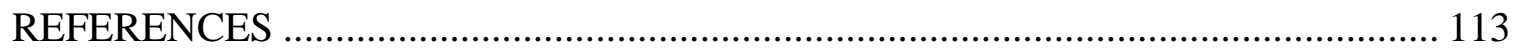

READY CHILD AND READY SCHOOL SURVEY ….................................... 127

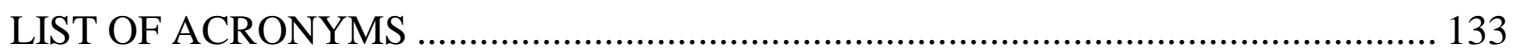

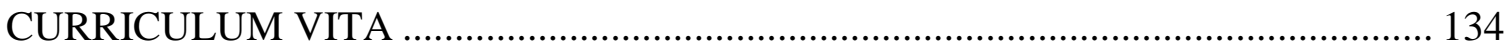




\section{LIST OF TABLES}

TABLE PAGE

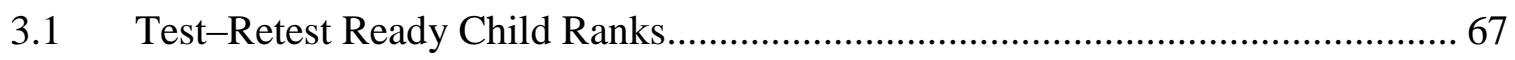

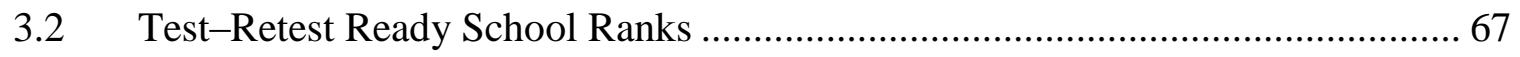

3.3 Summary of Section III Ready School Test-Retest Correlations (Pearson r)

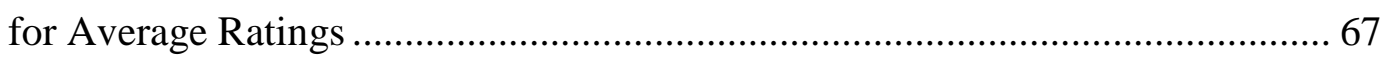

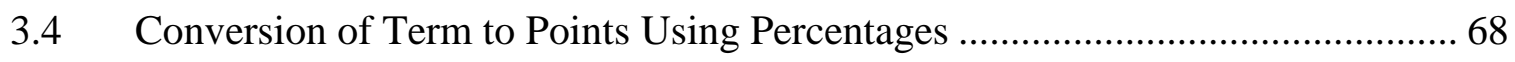

4.1 Below State Average and Above State Average Study Participants .................. 76

4.2 Comparing Free or Reduced Lunch Rates for Below State Average and

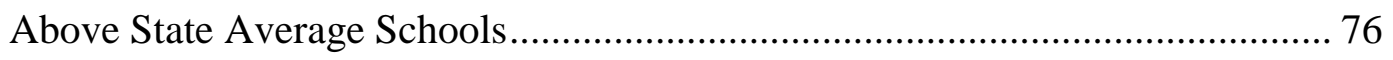

4.3 Years of Service for Below State Average and Above State Average

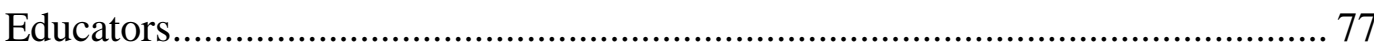

4.4 Ready Child Median Rankings Comparing Role Groups and Combined

Educator Sample (and whether there was a significant difference based on

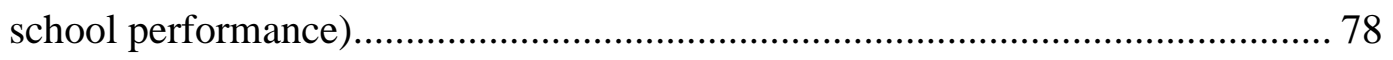

4.5 Significant Differences Observed for Rankings of Ready Child Indicators ......... 79

4.6 Principal Percentage Rankings of Health and Physical Well-Being .................. 79

4.7 Pre-Kindergarten Teacher Rankings of Approaches to Learning .......................... 80

4.8 Overall Educator Rankings of Approaches to Learning ................................ 80

4.9 Ready School Median Rankings Comparing Role Groups and Combined

Educator Sample (and whether there is a significant difference based on their

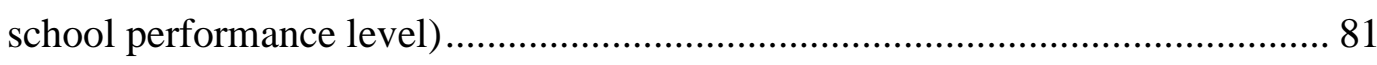


4.10 Significant Differences Observed for Rankings of Ready Child Indicators ......... 82

4.11 Kindergarten Teacher Ready School Rankings of Transition ............................ 82

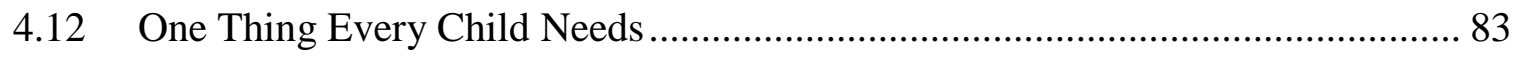

4.13 One Change to Make the School More Successful........................................... 84

4.14 Median Ready School Ratings Comparing Role Groups and Combined Educator Sample (and whether there was a significant difference based on

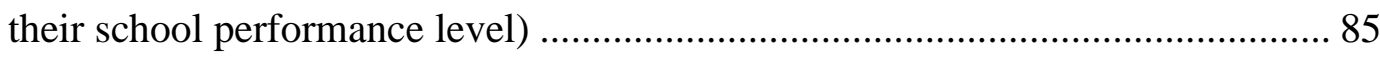

4.15 Significant Differences Observed for Ratings of Ready School Practices .......... 85

4.16 Combined Below State Average and Above State Average Educator Ratings

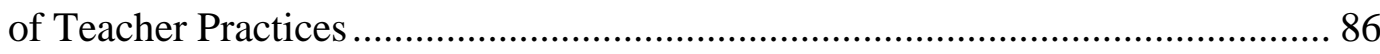

4.17 Correlations Between Above State Average and Below State Average Principal Responses on Ready Child Indicator Rankings (1-5) and Ready

School Practices (6-11) 87

4.18 Correlations Between Above State Average and Below State Average Principal Responses on Ready School Indicator Rankings (1-6) and Ready School Practices (7-12) 91

4.19 Correlations Between Above State Average and Below State Average Kindergarten Responses on Ready Child Indicator Rankings (1-5) and Ready School Practices (6-11)

4.20 Correlations Between Above State Average and Below State Average

Kindergarten Responses on Ready School Indicator Rankings (1-6) and Ready School Practices (7-12) 93 
4.21 Correlations Between Above State Average and Below State Average Preschool Responses on Ready Child Indicator Rankings (1-5) and Ready School Practices (7-12)

4.22 Correlations Between Above State Average and Below State Average Preschool Responses on Ready School Indicator Rankings (1-6) and Ready School Practices (6-12) 95

4.23 Overall Correlations Between Educator Rankings of Ready Child Indicators and Ratings of School Practices....... 96

4.24 Overall Correlations Between Educator Rankings of Ready School Indicators and Ratings of Ready School Practices 


\section{CHAPTER I \\ INTRODUCTION}

\section{Background}

In this study, the researcher considers educator perceptions of child readiness for school and school readiness for children conceptualized within the central constructs of the ready child and the ready school. The topic of school readiness has been broadened and redefined as a process that emphasizes preparing children for school, which is equally as important as preparing schools for children. Kindergarten is considered the beginning of "school" for which children need to be ready. The skills and abilities that children bring to the school are equally as important as the services and supports the school brings to the children.

According to the National Center for Education Statistics (2009), every year, more than 3 million children enter public school for the first time-all with their own set of skills, abilities, and talents. As the demand for student achievement increases, expectations also increase that young children will enter Kindergarten with the prerequisite skills that will make them ready for school. Early learning is increasingly recognized as one solution to problems of low achievement in elementary and secondary schools (Duncan et al., 2007; Enwisle, Alexander, \& Olson, 2005; Jones, 2005; LaParo, \& Pianta, 2000; Schweinhart et al., 2005).

Interest and concern are growing concerning children's readiness for school, and the ready child has become one of the most pressing issues facing the United States 
(Winsler et al., 2008). Much of the interest has likely occurred because of the No Child Left Behind Act (NCLB) of 2002 that established Grade 3 as the pivotal point of accountability and confirmed early learning as the foundational period in which to prepare children for school. However, many children enter school lacking the skills that they need to profit from "educational experiences in kindergarten and first grade" (Zigler, Gilliam, \& Jones, 2006, p. 21).

In 2007, many Kentucky school districts began to "test" children to determine whether they were ready for Kindergarten. During that time, the researcher was the director of early childhood education for the Kentucky Department of Education (KDE) and was concerned that children were being held accountable for having certain skills and knowledge upon entering school, yet the schools were not held accountable for being prepared and ready for every child. The concern led to the topic for this study.

The impact of high-quality early learning experiences concerning the ready child has been well established. Unfortunately, only a small proportion of children have access to high-quality preschool programs before they enter Kindergarten (Rouse, Brooks-Gunn, \& McLanahan, 2005). Nationally, 30-40\% of children who enter Kindergarten do not have the skills they need to be successful in school (Denton \& West, 2002). Several longitudinal studies reveal that participation in high-quality preschools is predictive of high school graduation, and college and career readiness (Reynolds, Temple, Robertson, \& Mann, 2002; Schweinhart et al., 2005). However, without quality, early learning experiences, the ready school becomes critically important for students who are unprepared for Kindergarten and are academically at-risk. The school environment sets the stage for future development, providing successful learning experiences, supports, 
and resources; therefore, the need for the ready school has never been greater (Copple \& Bredecamp, 2009).

It was desirable to study Kentucky children and schools because the State of Kentucky has been a forerunner in educational reform since 1989 when the courts ruled on Rose v. Council (Hoyt, 2008). The court found that public school financing was unconstitutional, Kentucky's system of common schools was unconstitutional, and the legislature must recreate the public school system (Hoyt, 2008). In response, the Kentucky General Assembly passed the Kentucky Education Reform Act of 1990 (KERA), one of the first statewide educational reform efforts in the nation. Thus, began the transformation of Kentucky's public education system.

Kentucky is also nationally known for early childhood initiatives and programs that make the state an ideal setting in which to study early childhood issues. More information about Kentucky is discussed later in this chapter.

\section{Historical Perspective}

During the 1990s, according to the first of six goals established by the National Education Goals Panel (NEGP; 1990), national attention was focused on child readiness for school. The NEGP set high standards for education performance from preschool to adulthood. The goals were later expanded to eight goals and were codified under the Goals 2000: Educate America Act of 1994.

Few people would dispute the importance of Goal 1: "by the year 2000 all children in America would start school ready to learn." Unfortunately, by the year 2000, child readiness for school was still a challenge. The readiness goal appeared simple; however, it was much more complex. The ready child requires a systemic approach that includes health, family supports, and access to high quality preschools; as a nation, we 
were not prepared to provide quality support structures and systems. In 2002, President George W. Bush did not reauthorize the Goals 2000: Educate America Act (1994); however, the concept of the ready child continued to capture attention at state and national levels because Goal 1 (every child ready for school) provided the foundation to achieve several other educational goals that continue to be desired outcomes for students: (a) improved graduation rate; (b) proficiency in core content (now referred to as common core standards);, and (c) schools that promote partnerships to increase parental involvement.

In reference to the goal of improved graduation rate, early childhood studies provide evidence that high-quality, early learning experiences and instruction produce higher achievement rates, higher graduation rates, lower remediation rates, more collegegoing students, and higher incomes (Hemmeter, Townley, \& Wilson, 1997; Reynolds et al., 2002; Schweinhart et al., 2005). Related to proficiency in core content areas, early foundation in content areas such as language, mathematics, reasoning, and problem solving contribute to later mathematics, reading, and science achievement (Duncan et al., 2007; Shonkoff \& Phillips, 2000). Finally, the goal of parental involvement is important. Active parental involvement and family engagement correlates with student achievement (Dearing, Kreider, Simpson, \& Weiss, 2008; Graue, Clements, Reynolds, \& Niles, 2004; Protheroe, 2006) and the federal Head Start program considers family involvement so important that it is one of the required performance standards (Office of Head Start, 2010).

In 2002, Congress passed one of the most sweeping educational reforms in the Nation. NCLB (2002) was designed to promote a standards-based education to ensure that all students, especially those most at-risk of academic failure, would achieve at high 
levels. Measureable goals were established for schools and districts, and the districts that consistently failed to make adequate yearly progress were subject to corrective action. NCLB (2002) drew attention to the importance of early learning experiences to develop fundamental skills. Hernandez (2011) suggested that poor children who had not mastered reading by Grade 3 would likely fail in later grades and would be more likely to drop out before earning a high school diploma.

In response to the implications of NCLB (2002) for younger children, President Bush launched the Good Start, Grow Smart initiative in 2002 for early childhood programs (U.S. Department of Education, 2002b). State education agencies (SEAs) were encouraged and federal Head Start programs were required to develop and implement mathematics and literacy early learning guidelines (aligned to Kindergarten $[\mathrm{K}]-12$ standards) for 3-5-year-old children to ensure they would be ready for Kindergarten.

Ready child. The NEGP was established in 1990 and convened several Goal One workgroups - every child enters school ready to learn — to further clarify the meaning of the ready child. The objectives to meet the goal were (a) all children will have access to high quality, developmentally appropriate preschool programs; (b) every parent in the United States will be his or her child's first and most important teacher; and (c) children will receive the nutrition and physical activity experiences necessary to arrive at school ready to learn (Lewitt \& Baker, 1995).

The efforts of the NEGP (1990) Goal One workgroup resulted in the identification of five dimensions of child readiness for school that SEAs and professional early childhood groups have widely accepted, and that were included in the literature: (a) physical and motor development; (b) social and emotional development; 
(c) approaches toward learning - initiative, creativity, motivation to learn; (d) language development; and (e) cognition and general knowledge. The dimensions appealed to early childhood professionals because they addressed the whole child, and encompassed developmental domains and cognitive development (Ackerman \& Barnett, 2005; Blair, 2002).

Ready school. The NEGP (1990) also convened the Ready Schools Resource Group to identify attributes of a ready school (Shore, 1998). The final report identified 10 characteristics of a ready school:

1. Smoothes the transition between home and school.

2. Strives for continuity between early care and education programs and elementary schools.

3. Helps children to learn and make sense of their complex world.

4. Is committed to the success of every child.

5. Is committed to the success of every teacher and every adult who interacts with children during the school day.

6. Introduces or expands approaches that raise achievement.

7. Alters programs and practices if they do not benefit children.

8. Serves children in communities.

9. Takes responsibility for results.

10. Has strong leadership.

Unfortunately, the ready school has not received as much attention as the ready child, possibly because of limited literature on the topic and the priority of helping children be ready for school (Bracey, 2005; Burke \& Burke, 2005). 


\section{Child and School Readiness in Kentucky}

In 2000, under Governor George Patton, the Kentucky legislature made a decision to use $25 \%$ of tobacco settlement dollars for early childhood initiatives that funded KIDS NOW, a 20-year program to provide every child from birth to Age 4 "a strong foundation" for school success (Kentucky Governor's Office of Early Childhood, 2014). KIDS NOW, with an average budget of \$23 million, provides funding to many early childhood programs across the state to improve quality.

In 2002, Kentucky was the first state to develop early learning standards (ELS) from birth to Age 5 (U.S. Department of Education, 2002a). Kentucky's ELS include NEGP (1990) domains except approaches toward learning (motivation, attention and persistence, problem solving) which is not a separate ELS, but embedded within other domains and included in Kentucky's definition of school readiness (ready child).

In 2009, under Senate Bill 1 (Winters et al., 2009), the KDE began pursuing an aggressive agenda to graduate students who were college- or career-ready, and made child readiness for school (ready child) a strategy in the Kentucky Proficiency Plan to achieve that goal. In response, Governor Steve Beshear convened the Kentucky Early Childhood Task Force (2010; Executive Order 2009-232), cochaired by cabinet secretaries from Education and Workforce Development and Health and Family Services. The combination of the two cabinet secretaries to provide leadership to statewide early childhood programs was an unprecedented move. The task force was given the charge of defining the ready child. The members held several meetings and discussion clearly pointed to a commitment that Kentucky's definition would represent the whole child (Bagdi \& Vacca, 2006; Wesley \& Buysse, 2003). The task force further identified domains (identical to NEGP's) to address the whole child: (a) approaches to learning; 
(b) health and physical well-being; (c) language and communication development;

(d) social and emotional development; and (e) cognitive and general knowledge.

Although the focus has been on the ready child, the KDE (2012b) also included the ready school early on in the Proficiency Delivery Plan. The goal was that all children would be ready for school and every school would be ready and prepared for every child.

\section{Readiness Issues}

Two assumptions are made for child readiness for school: (a) all children are ready for school because they meet the age criteria established by state legislation; and (b) the majority of children are born ready to learn. Risk factors should not prevent children from entering Kindergarten even though they might not meet academic expectations once they arrive at the school door, which confirms the importance of the ready school (High, 2008; Perroncel, 2000).

Although they meet age criteria for Kindergarten, not all children are considered ready for school. Some differences in children are variations in development, while others are related to demographic factors such as poverty and parental education level; therefore, each child enters school with different strengths, skills, and weaknesses (Daily, Burkhauser, \& Halle, 2010; Wertheimen \& Croan, 2003). According to Zigler et al. (2006) the readiness gap exists for students who begin school significantly behind in early mathematics and early literacy and is "never closed but tends to widen as they move through school” (p. 21). The prerequisite skills needed for the next level of learning might not occur for some children without intervention and strategies to meet individual learning needs. Zigler et al. (2006) further contended that child readiness for school has been shown to be "predictive of every educational benchmark" (p. 21). If the child is not ready (lacks skills in and knowledge of early mathematics and prereading) and the school 
is not ready (ill prepared with supports and interventions), the child's school experiences might be negatively affected.

Although public schools are responsible for educating all children, historically, they have been more successful "educating middle to upper income and white children than poor and minority students" (Kannapel \& Clements, 2005, p. 2). Socioeconomic status (SES) is one of the greatest determinants of school success, more than race or ethnicity (Duncan, Morris, \& Rodrigues, 2011; Hart \& Risley, 1995; Lee \& Burkham, 2002). Analyses by Isaacs and Magnuson (2011) and Lee and Burkham (2002) of differences in social backgrounds relative to achievement at school entry found substantial differences in test scores depending on race and ethnicity, but the differences associated with SES were even more substantial. Darling-Hammond (2010) suggested schools that serve low SES families compared to schools with families that are more affluent have less qualified teachers and less extensive curricula. Therefore, even if children of low SES families are well prepared when they enter Kindergarten, if they enter a school with a student body characterized by low SES, the school might lack the capacity to move them to higher achievement (Daily et al., 2010).

\section{Statement of the Problem}

A disconnection exists between child readiness expectations (ready child) and public school requirements and expectations (ready school). The conversation of school readiness typically means child readiness for school. Educators have a knowledge void regarding whether schools need to be ready and prepared for every child. In general, if the goal is that all children will enter school ready to learn, schools play a major role in being prepared and ready for every child. 


\section{Purpose}

The purpose of the study was to identify the differences between two groups of educators, from successful and unsuccessful elementary schools, concerning their perceptions of ready child and ready school success indicators and the frequency of implementing ready school practices. The results provide recommendations to establish ready schools at preschool through Grade 3.

\section{Significance}

This study is significant for several reasons. First, a national plan or standards for school readiness (ready child) does not exist although federal programs (e.g., those that Head Start and the Race to the Top Early Learning Challenge Fund promote) and such standards would require additional programs and initiatives to address the ready child. Federal policy initiatives are going forward without a national consensus on the concept of ready child and ready school. Although this study includes a sample of educators from one state (Kentucky), it will contribute to public discourse, early childhood pedagogy, and literature, and will provide information to educators who face federal program and grant requirements.

Second, in an environment of accountability to assure student achievement, high school graduation, and college and career readiness, ready child and ready school concepts are important to establishing an early foundation. As superintendents and school leaders seek strategies and resources to assure positive academic outcomes, the researcher provides in this study useful information on the ready child and ready school to target resources and support that might yield greater outcomes for students.

Third, the researcher's findings from the study might support the creation of ready schools that are focused on early learning experiences such as the FirstSchool movement. 
FirstSchool is a philosophy of early learning to create preschool to Grade 3 schools (Ritchie, Maxwell, \& Clifford, 2009). The Frank Porter Graham Child Development Institute (2011) at the University of North Carolina at Chapel Hill originated the idea.

Finally, the study extends the literature and research on the ready child and the ready school. A few authors considered the importance of ready child indicators, yet limited research was found on the nature of the ready school.

\section{Research Questions}

The researcher asked three research questions pertaining to principals, Kindergarten teachers, and preschool teachers from Kentucky elementary schools whose Grade 4 reading and mathematics scores on the 2011-2012 K-PREP were below state average (BSA) or above state average (ASA).

1. Do differences exist in educator rankings of ready child indicators when comparing:

a. Role groups (principals, Kindergarten teachers, and preschool teachers) across school performance levels (BSA or ASA); and

b. Combined educator sample across school performance levels?

2. Do differences exist in educator rankings of ready school indicators when comparing:

a. Role groups (principals, Kindergarten teachers, and preschool teachers) across school performance levels (BSA or ASA); and

b. Combined educator sample across school performance levels?

3. Do differences exist when:

a. Comparing BSA and ASA educator ratings of ready school practices; and 
b. Correlating ratings of ready school practices to rankings of ready child and ready school indicators between BSA and ASA educators and combined role groups?

\section{Definitions}

\section{The Ready Child}

In the literature, readiness and school readiness usually refer to the child's readiness. In this study, child readiness for school is referred to as ready child. The ready child is the typically developing child who by an identified age is ready to learn in a formal school setting (Carlton \& Winsler, 1999; Saluja, Scott-Little, \& Clifford, 2000). The Ready School

Ready school refers to the readiness and preparedness of schools for children. The ready school has six features:

1. Implements an engaging, culturally relevant curriculum.

2. Involves families in decision making and other meaningful activities.

3. Has teachers who make intentional instructional decisions.

4. Employs a continuous assessment process.

5. Has leadership committed to the success of every student.

6. Implements a comprehensive transition program.

Several resources and references were used to define ready school and they are discussed more fully in Chapter II. Primarily, they include (a) the NEGP (1990) Readiness Resource Group's key dimensions of a ready school, (b) High/Scope Educational Research Foundation (High/Scope) Ready School Assessment (RSA; 2006b), (c) Developmentally Appropriate Practices (Copple \& Bredecamp, 2009), and 
(d) research on effective schools and high performing schools. The ready school indicators identified for this study are (a) curriculum; (b) families; (c) teachers;

(d) assessment; (e) leadership; and (f) transition.

Successful Schools (for this study)

Successful schools in this study are defined as schools whose Grade 4 reading and mathematics scores on the K-PREP were ASA. The K-PREP state average for 20112012 was 44.3 for reading and mathematics.

Unsuccessful Schools

In this study, the researcher defines unsuccessful schools as schools whose Grade 4 reading and mathematics scores on the K-PREP were BSA. The K-PREP state average for 2011-2012 was 44.3 for reading and mathematics.

Kentucky's High Poverty Schools

The high poverty schools in this study are those that met or exceeded the state average for free or reduced price lunch (FRL) which was 55\% (KDE, 2012a). At-Risk Students

The literature suggested that a correlation exists between SES and school success. At-risk students in this study are identified based on family SES. Several studies (Duncan et al., 2011; Evans, 2004; Hart \& Risley, 1995; Lee \& Burkham, 2002) confirmed that SES is strongly related to student cognitive skills and is the greatest determining factor for vocabulary development.

Early Childhood

Early childhood is the period of development from birth through Age 5 (U.S. Department of Education, 2002b). This stage of rapid growth and development builds the foundation for later development and learning in literacy, mathematics, and science 
(Bowman, Donovan, \& Burns, 2000; Crone \& Whitehurst, 1999). However, the National Association for the Education of Young Children (NAEYC, 2009) considers early childhood to be from birth through Age 8. For this study, it is more appropriate to consider early childhood as birth through Kindergarten because this study is about children who are entering school (Kindergarten) for the first time.

\section{Head Start Program}

Head Start is a federal program funded through the U.S. Department of Health and Human Services for low-income children and families. The goal of Head Start is to help preschoolers develop early reading and mathematics skills to prepare for school. Head Start performance standards focus on health, nutrition, education, and parent involvement. In most instances, Head Start programs are federal to local—not administered by SEAs or school districts (i.e., local education agencies [LEAs]). In this study, Head Start teachers are considered preschool teachers.

\section{Effective Schools}

"Effective schools" is a term used in the 1970s and early 1980s for schools that were successful in educating all students. They have certain common characteristics: (a) effective leadership, (b) climate of high expectations, (c) emphasis on teaching and learning, and (d) on-going assessment of student progress (Brookover \& Schneider, 1975; Lezotte, 1992; Ravitch, 1984). Practices in effective schools reflect ready school indicators in this study.

\section{High Performing Schools}

The literature and research suggest that schools that are identified as highperforming produce higher levels of achievement for at-risk (low-SES) students. They are typically identified as high-performing and high-poverty (HP/HP) schools. The most 
common characteristics of high-performing schools are strong leadership, high expectations, effective teaching, and parent involvement, which are similar to characteristics of effective schools (Kannapel \& Clements, 2005). They also align to ready school indicators selected for this study.

2011 Race to the Top Early Learning Challenge Fund

The 2011 Race to the Top Early Learning Challenge (ELC) Fund (McGuinn, 2011) was a competitive application process to grant funds to states that demonstrated a comprehensive, statewide system to promote and increase high-quality, early childhood programs, especially for high-needs children (i.e., at-risk children, English language learners, children with disabilities). The goal of the ELC Fund was to ensure that children would enter Kindergarten with the skills and knowledge to be successful learners.

\section{Summary}

Accountability under NCLB (2002) reinforced the importance of early learning experiences for successful school entry and subsequent achievement, but not all children have the opportunity for participation in high-quality programs before Kindergarten. Most children enter school simply because they are age-eligible. Nevertheless, age alone does not provide sufficient information to help schools meet the learning needs of each child. Demographic challenges such as poverty might present barriers to academic achievement.

The NEGP (1990) defined ready child dimensions and ready school characteristics, but a national plan does not exist that includes both constructs. This study explores whether the ready child and ready school indicators that educators consider important and the ready school practices that are implemented at high-levels correlate to successful students and schools. 
In this chapter, the researcher discussed (a) background information on ready child and ready school, (b) a historical perspective, (c) child and school readiness in Kentucky, (d) readiness issues, (e) a statement of the problem, (f) the purpose of the study, (g) the significance of the study, (h) the research questions, (i) the methods of the study; and (j) the definition of the terms.

In Chapter II, the researcher provides a literature review on the topics of (a) the ready child, (b) the ready school, (c) effective schools, and (d) high-performing schools. The chapter also includes the conceptual framework and the justification for the research questions.

In Chapter III, the researcher discusses the methodology for the study. In Chapter IV, the researcher organizes and reports the results and, in Chapter V, the results are interpreted and discussed as they relate to the research questions and recommendations for policy and practice. 


\section{CHAPTER II \\ LITERATURE REVIEW \\ Introduction}

This chapter covers several areas of the literature and research concerning child and school readiness. In the first section, the researcher considers the concept of the ready child and what authors in the literature identified as indicators important for successful transition to Kindergarten and subsequent school success. In the second section, the researcher describes the ready school, that is, schools that are prepared and ready for children. Research on the ready school is limited; therefore, the third and fourth sections of this chapter include literature and research about features and characteristics of effective schools and high performing schools, respectively, to support ready school indicators identified for this study. The fifth section of this chapter connects ready child and ready school constructs within a conceptual framework, including research support for ready child and ready school indicators. The last section provides the justification for the research questions.

\section{The Ready Child}

Foundation of the Ready Child Concept

The first priority of the Goals 2000: Educate America Act (2004) was that every child in America would begin school ready to learn (Shore, 1998). Although the goal is certainly important to set the foundation for successful school experiences, defining what readiness means for each child is difficult (Carlton \& Winsler, 1999; Daily et al., 2010; 
Wertheimen \& Croan, 2003). Many people would agree that the future success of a child is dependent upon him or her being ready to learn. However, the one eligibility criterion for school readiness for most states has been the child's chronological age (Ackerman \& Barnett, 2005), assuming that it equates to certain levels of knowledge and skills that make the child ready for school (Bisanz, Morrison, \& Dunn, 1995; Grissom, 2004; ScottLittle, Kagan, \& Frelow, 2006).

Ready child is a complex, multifaceted construct that is difficult to articulate (Scott-Little et al., 2006; Wesley \& Buysse, 2003). Children enter Kindergarten with widely varying skills that are dependent upon previous preschool and home experiences as well as the quality of interactions and experiences that occur within the environments (Ackerman \& Barnett, 2005; Perroncel, 2000). Parents, teachers, and community members might differ in their expectations for the ready child, which adds to the complexity (Duncan et al., 2007; Piotrkowski, Botsko, \& Matthews, 2001).

The notion of ready child assumes that a child is ready for school and ready to learn; however, a difference exists between the two concepts. Some educators consider readiness for school as a set of prerequisite skills and knowledge to fulfill requirements and expectations of the school (Lin, Lawrence, \& Gorrell, 2008; Meisels, 1999), which means that a child is ready to be successful in a typical school environment (Carlton \& Winsler, 1999).

Readiness to learn is conceptualized as a developmental progression and the point (age) at which a child is ready to learn specific content (Crone \& Whitehurst, 1999; Howes et al., 2008; Stipek \& Byler, 2001). Perroncel (2000) argued that all healthy children are born ready to learn. Another view is that readiness to learn depends on a range of factors, including health and wellness, physical development, and social 
development. Therefore, efforts to support the ready child—-from an optimal standpoint - begin long before he or she enters school and such efforts involve the child and family, health and welfare, and early childhood programs (Perroncel, 2000; Saluja, Scott-Little, \& Clifford, 2000; Wesley \& Buysse, 2003).

The NAEYC (2009) entered the ready child conversation by taking a position in 1995 to ensure that the needs of children would be addressed through resources and services to help each child reach his or her full potential. NAEYC believes that a commitment to the ready child requires schools to provide to every child access to opportunities for school success.

All states have identified what children should know and be able to do in Kindergarten, but not all states have collected the ready child data of the expected skills and abilities. The State of Maryland is a trailblazer for collecting readiness assessment data. The Maryland Department of Education began the Maryland Model for School Readiness (MMSR) Kindergarten Test in 2001. The MMSR evaluates what Kindergarteners should know and be able to do across seven domains: social and personal development, language and literacy, mathematical thinking, scientific thinking, social studies, arts, and physical development (Maryland Department of Education, 2011). The scoring process determined whether children were fully, approaching, or developing readiness skills for Kindergarten.

The 2011-2012 MMSR report (Maryland Department of Education, 2011) revealed that $83 \%$ of all Kindergarten students were ready for school compared to $46 \%$ when the initiative began. The percentage of children from low-income homes who were ready for Kindergarten increased from 34\% in 2001 to $76 \%$ in 2012 (Maryland Department of Education, 2012). The dramatic change occurred over time, so that state 
officials, district leaders, and school leaders focused their efforts on the results of the Kindergarten readiness assessment to drive professional development and improvements in schools and early childhood programs. Maryland readiness data also revealed a direct link between Kindergarten readiness and Grade 3 mathematics and reading scores on the state assessment. In the 2011-2012 MMSR report, children who entered Kindergarten "fully ready" were " 8 times more likely to be proficient in both math and reading" by Grade 3 (Maryland Department of Education, 2012, p. 5).

Definition of the Ready Child

Much of the literature and research considers the ready child as multifaceted (Meisels, 1999; National Center for Research in Early Childhood Education, 2010; Rimm-Kaufman, Pianta, \& Cox, 2000; Scott-Little et al., 2006; Shore, 1998). A national, common definition of the ready child has not been embraced partly because wide variations exist in the perceptions of readiness, which are influenced by cultural, political, and institutional systems (Graue, 1993; Wesley \& Bussey, 2003) and because little consistency exists across school readiness initiatives.

Scott-Little et al. (2006) conducted a content analysis of early childhood standards documents from 46 states, Kentucky included. They used the child readiness standards from the NEGP (1990) and coded state standards across five dimensions: (a) physical well-being and motor development, (b) social and emotional development, (c) approaches toward learning, (d) language and communication development, and (e) cognition and general knowledge. All 46 state documents addressed cognition and general knowledge and language and communication development in their standards. The next most commonly addressed domains were the social-emotional domain and approaches toward learning. 
Kentucky's early learning standards (ELS) include NEGP (1990) domains, except approaches toward learning (motivation, attention and persistence, problem solving), which is considered one of the most important domains that contributes to school success (Fantuzzo, Perry, \& McDermott, 2004; Scott-Little et al., 2006). Although "approaches toward learning" is not a separate ELS, it is embedded within other domains and included in Kentucky's definition of school readiness (ready child).

Scott-Little et al. (2006) concluded, in lieu of a formal definition of the ready child, that state early childhood standards were often used to conceptualize expectations of children's readiness for Kindergarten. Their study gives a national perspective of what state education officials have noted as important indicators for the ready child.

In 2007, the researcher of this study conducted a survey for the KDE of Kentucky's school districts about school readiness practices (KDE, 2010). More than $60 \%$ of Kentucky's school district preschool coordinators (106 of 174) responded to the survey. A large majority of the respondents (94\%) did not have a definition for school readiness, yet most $(60 \%)$ were implementing a readiness screener, which was an indication that ELS were used to define child readiness for school (ready child) and confirmed Scott-Little et al.'s (2006) findings.

The Kentucky Early Childhood Task Force (2010) was given the charge to define school readiness or ready child. The task force members reviewed literature from the NEGP (1990) Readiness Resource Group and other state definitions and policies. The final definition indicated that, in Kentucky, the ready child is a child who "enters school ready to engage in and benefit from early learning experiences that best promote the child's success." 


\section{Researcher's Operational Definition of the Ready Child}

The researcher agrees with the holistic view of the ready child. The ready child is one who is developmentally ready to learn; is physically healthy; is curious; speaks in complete sentences and understands the association between letters, print, and reading; is socially responsive to others; and has a general knowledge of mathematics and science concepts. Physical, social, and cognitive domains are interrelated and together define the ready child.

\section{Ready Child Gaps}

The ready child can be adversely affected by certain risk factors such as poverty, mother's education level, the child's health, and living environments (Bracey, 2005; Bradley \& Corwyn, 2002; Evans, 2004; High, 2008; Isaacs, 2012; Lee \& Burkham, 2002). For many children the inequality exists well before Kindergarten, so previous early learning experiences play a critical role in child readiness for school (Bradley \& Corwyn, 2002; Rouse, Brooks-Gunn, \& McLanahan, 2005; Sameroff \& Fiese, 2000). When children from economically disadvantaged backgrounds enter Kindergarten, substantial gaps in cognitive development and academic competencies continue to exist in spite of gains that might occur from participation in high-quality, early childhood programs (Farkas \& Beron, 2004; Raver, Aber, \& Gershoff, 2007; Stipek \& Ryan, 1997; Wright, Diener, \& Kay, 2000).

Several studies reveal gaps are present when children enter school. The Early Childhood Longitudinal Study-Kindergarten (ECLS-K) study conducted by West, Denton, and Germino-Hausken (2000) followed a nationally representative sample of 22,000 children who were entering Kindergarten in the fall of 1998. West et al. used questionnaires to gather baseline data from parents and teachers. Individual assessments 
were used to collect data on children's cognitive skills, health and wellness, social skills, mathematics, and family environment. Their study produced several findings pertinent to this study: (a) children's performance increased with the level of the mother's education, (b) kindergartners' general health differed according to mother's level of education and whether or not the family used public assistance, and (c) children not at risk persisted more at tasks (approaches to learning) than children who were at risk of school failure.

Lee and Burkham (2002), in their analysis of the ECLS-K study, found that SES strongly related to cognitive skills more than did race and ethnicity, family education levels, or home environments. Children from high-income homes scored $60 \%$ higher on cognitive tests than children from low-income homes. Lee and Burkham also found that low-SES children begin Kindergarten at lower-quality schools. High-quality schools were described as schools that have higher student achievement, more resources, teachers that are more qualified, teacher attitudes that are more positive, and locations in higher-SES neighborhoods.

In an earlier study, Hart and Risley (1995) studied 42 children over a period of 2 years and confirmed that SES was the greatest determining factor for vocabulary development and contributed to a large vocabulary gap between lower- and higherincome homes before children entered school. They found that the differences between families were not in the kinds of experiences between parents and children, but rather in the number of interactions and the richness of conversations. Hart and Risley found that by Age 3, children from low-income homes had a vocabulary of 420 words and children from higher-income homes had a vocabulary of 1,100 words.

Duncan et al. (2007, 2011), and Evans (2004) also suggested that SES makes a difference in later school achievement. The research is important to this study because all 
of the sample elementary schools whose K-PREP reading and mathematics scores fall BSA have high-poverty student populations (i.e., FRL student populations). However, $49 \%$ of the sample schools whose K-PREP scores are ASA are also considered highpoverty schools.

Ready Child Indicators from the Literature and Research

Views about which ready child indicators are considered most important for school success are yet polarizing. Some researchers argued that academic and cognitive skills are more important while others are concerned with social and emotional development (Ackerman \& Barnett, 2005; Haradine \& Clifford, 1996; Protheroe, 2006; Raver \& Zigler, 1997). Some researchers provided evidence that social and emotional skills strongly relate to the ready child and are as important as cognitive and academic competence (McClelland, Morrison, \& Holmes, 2000; Rimm-Kaufman, Pianta \& Cox, 2000; Shonkoff \& Phillips, 2000; Wright et al., 2000). Other researchers linked academic, cognitive, and social development to child readiness for school (LaraCinisomo, Fuligini, Ritchie, Howes, \& Karoly, 2008; Linares et al., 2005; Raver et al., 2007; Stipek \& Byler, 2001).

LaParo and Pianta (2000), in their meta-analysis, found middle range correlations in academic and cognitive skills in preschool to Kindergarten (.43) and Kindergarten to Grades 1 and 2 (.48) achievement. Duncan et al. (2007) conducted a meta-analysis of six longitudinal data sets and found that early mathematics skills were the most powerful predictor of early learning with standardized coefficients ranging from .05 to .53 , followed by early language and reading skills. In contrast, Duncan found no connection between social and emotional readiness skills and later achievement. However, some teachers emphasized the importance of social and emotional behavior and believed that 
they shape positive classroom behavior, which leads to achievement (Ackerman \& Barnett, 2005). The evidence suggested that both social emotional development and cognitive skills and abilities are important to the ready child.

In some studies, teachers and parents had differing views about ready child indicators. Parents focused on cognitive skills such as mathematics and reading, while teachers viewed emotional development and good health as more important (Ackerman \& Barnett, 2005; Lewitt \& Baker, 1995; Protheroe, 2006).

A difference also existed in parent perceptions of ready child success indicators between low-SES and high-SES homes. West, Hausken, and Collins (1993) surveyed parents using a questionnaire and found that the majority of parents from low-SES homes believed that academic skills were more important than did parents who were college graduates. One study that examined the belief systems of 155 Head Start parents (low SES) revealed that more than $82 \%$ of them believed that it was necessary for children entering Kindergarten to know their colors, letters, and be able to count (Piotrkowski, 2004).

A study by Piotrkowski, Botsko, and Matthews (2001) compared belief systems between parents, preschool, and Kindergarten teachers in a high needs community about what children should know at school entry. The researchers developed a survey that included the five NEGP (1990) dimensions of school readiness: (a) approaches to learning, (b) health and physical well-being, (c) language and communication, (d) social and emotional development, (e) and cognition and general knowledge. Piotrkowski et al. (2001) categorized the dimensions in areas of general readiness that included health, physical wellness, and classroom readiness such as language, cognitive, and general knowledge. The participants in the study were 355 parents, 52 preschool teachers, and 57 
Kindergarten teachers. Across all three groups, the participants agreed that health, peer relationships, and emotional maturity were very important for general readiness. For classroom readiness, participants in all three groups agreed that it was very important that children pay attention and listen to the teacher. Parents also believed that basic knowledge (e.g., knowing the ABCs and counting) were very important for the ready child, while preschool and Kindergarten teachers rated these two areas as least important and considered social competence and effective communication as more important.

Wright et al. (2000) found different results in their study. They used a mixedmethods approach to gather data on ready child indicators. The goal of their research project was to gain information about the readiness skills necessary for school success. Their sample included 30 Kindergarten teachers and 11 elementary school principals in high-poverty schools. The majority of the principals (63\%) rated social skills and parenting as most important for the ready child, while the teachers rated literacy (64\%) and academic skills (50\%) as most important readiness indicators for school success.

Another study examined beliefs of preschool teachers and childcare educators about what children need to be ready for Kindergarten (Lara-Cinisomo et al., 2008). Lara-Cinisomo et al. (2008) used qualitative data to analyze perceptions about the ready child. They administered a standardized interview protocol to 81 participants across three types of program settings - public, private, and family. The results indicated that all groups believed that the ready child needed to be "emotionally (confident, motivated), physically (healthy, with good motor skills), cognitively ready (alphabet, numbers, problem-solving) and have good social skills" (p. 347) to be successful in Kindergarten. The indicators of the ready child that they identified align to the dimensions recommended by the NEGP (1990) Readiness Resource Group. 
Hair, Halle, Terry-Humen, Lavelle, and Calkins (2006) examined how multiple school readiness domains worked together to predict academic and social adjustment. They conducted two studies using a cohort of 17,219 first time Kindergarteners from the Early Childhood Longitudinal Study-Kindergarten (ECLS-K) Class of 1998-1999. In the first study, they examined how different dimensions (e.g., health, cognition, social, and emotional development) predicted strengths and risks for students at the beginning of Kindergarten. The second study used those results to predict Grade 1 outcomes, controlling for classroom and child background characteristics. Their analyses revealed that the quality of the child's Kindergarten experience was positively related to Grade 1 mathematics and reading scores. Essentially, characteristics of the school can affect the children's achievement or failure, which supports the need for ready schools, discussed in the next section.

\section{Ready Child Indicators for the Study}

The authors in the literature and research suggested that the following indicators are important to the ready child; therefore, they have been selected for this study:

1. Approaches to learning is considered one of the most important skills for $21 \mathrm{st}$ century learning. It means how well the child is motivated to learn, how well he or she pays attention to his or her learning, and how well he or she persists in tasks and problem solving (Copple \& Bredecamp, 2009; Daily et al., 2010; Kagan, Moore, \& Bredecamp, 1995). These skills are observable and associated with later school achievement (McClelland, Morrison, \& Holmes, 2000; McDermott, Mordel, \& Stolzfus, 2001; Yen, Konold, \& McDermott, 2004). 
2. Health and physical well-being are important for young children. Nutrition, physical health, and gross and fine motor skills have an effect on child learning (West et al., 2001). Development of fine motor skills help children improve in activities such as sorting small objects, holding scissors, painting, drawing, and writing, all of which predict later school success (Copple \& Bredecamp, 2009; Greer \& Lockman, 1998; NCRECE, 2010).

3. Language and communication includes listening, speaking, vocabulary, and print awareness. These skills and experiences are important for school success and critical for fluency and understanding more complex text (Duncan et al., 2007; Snow, Burns, \& Griffin, 1998; Strickland, 2006; Starch \& Whitehurst, 2002; Whitehurst \& Lonigan, 1998; Wright et al., 2000).

4. Social and emotional development are linked to subsequent academic achievement because these skills provide the foundation for a formal school environment, strongly relate to school readiness, and contribute to school success (Enwisle et al., 2005; Konold \& Pianta, 2005; Lara-Cinisomo et al., 2008; Linares et al., 2005; Raver et al., 2007; Stipek \& Byler, 2001).

5. Cognitive and general knowledge means thinking, reasoning, and concepts of mathematics and science. Reasoning and problem solving promote higherlevel thinking and learning (Blair, 2002; Copple \& Bredecamp, 2009). Researchers suggested that early mathematics skills contribute to later mathematics and reading achievement and have the greatest predictive power for student achievement (Duncan et al. 2007; Ferri \& Stemberg, 1998; NCRECE, 2010). LaParo and Pianta (2000) found middle range correlations 
between cognitive skills and preschool to Kindergarten and KindergartenGrade 2 achievement

Summary of the Ready Child

Researchers suggested that healthy children are born ready to learn; however, the ready child might not meet expectations for school readiness because of previous experiences and demographic factors. Although views differed concerning what makes a child ready for school, most researchers agreed that the concept of the ready child is multidimensional and includes behavioral, emotional, and cognitive domains that are interrelated and together allow the child to be ready for school (Blair, 2002).

The ready child indicators identified for this study represent a multidimensional, child-centered approach supported by the literature and research. They are the same ready child indicators included in Kentucky's definition of school readiness and ready child dimensions from the NEGP (1990) Readiness Resource Group, which are (a) approaches to learning, (b) health and physical well-being, (c) language and communication, (d) social and emotional development, and (e) cognitive and general knowledge.

This section included discussions of (a) the foundation of the ready child concept, (b) definition of the ready child, (c) ready child gaps, (d) ready child indicators from the literature, and (e) ready child indicators selected for this study. The next section is a review of the literature and research on the ready school and provides support for ready school indicators identified for this study.

The Ready School

Foundation of the Ready School Concept

The ready school concept grew out of the creation of the NEGP (1990) Ready Schools Resource Group to support Goal 1 that all children would enter Kindergarten 
ready to learn (Shore, 1998). In 1998, the NEGP (1990) convened a group of national early childhood advisors who formed the Ready Schools Resource Group. Their charge was to identify attributes of a ready school. The final report suggested broad strategies for schools and communities to strengthen the transition to Kindergarten-Grade 3. They identified Ten Keys to Ready Schools which are schools that (a) smooth the transition between home and school (b) strive for continuity between early childhood programs and schools, (c) help children make sense of their complex world, (d) commit to the success of every child,

(e) commit to the success of every teacher and adult, (f) introduce or expand approaches that raise achievement, (g) alter ineffective practices and programs, (h) serve children in communities, (i) take responsibilities for results if they do not work, and (j) have strong leadership. According to the Ready Schools Resource Group, many effective schools implement the practices to get "children off to a good start" (Shore, 1998, p. 4).

The idea of a ready school is a significant change to the concept of child readiness for school. The focus of school readiness previously relied solely on the child, but the construct of readiness has been broadened and redefined as a process that emphasizes preparing schools for children (i.e., the ready school), which is equally as important as preparing children for school (i.e., the ready child; Boyer, 1992; Bracey, 2005).

The shift to higher expectations for schools and students under NCLB (2002) and common core standards illustrates the need for the ready school. Many have examined the positive effects of quality preschools in preparing young children for school (Hemmeter, Townley, \& Wilson, 1997; Huang, Invernizzi, \& Drake, 2011; Sharif, Ozuah, \& Dinkevich, 2003; Schweinhart et al. 2005; Vakil, Freeman, \& Swim, 2003), yet 
too many children who enter Kindergarten have not had high-quality, early learning experiences, which makes the ready school important (High, 2008).

Features of the Ready School

According to Early, Pianta, Taylor, and Cox (2001), one of the features of a ready school is that it engages families in effective transition activities to help them support their children. Further, they suggested that a ready school has three characteristics:

(a) reaches out to link families and communities to schools, (b) makes connections before the first day of school, and (c) reaches out with appropriate intensity. Early et al. also found that high-poverty urban areas did not implement practices at the same level as lowpoverty areas, but instead had minimal transition activities such as orientations and open houses that occurred after the beginning of the school year.

High/Scope (2006a) leads the field in promoting the ready school. Its work produced the RSA, intentionally designed to "bring together the best of early childhood and elementary education standards” (p. 3). The High/Scope (2006b) RSA profile identifies eight key dimensions or features of a ready school:

1. Leaders and leadership.

2. Transitions.

3. Teacher supports.

4. Effective curricula.

5. Engaging environments.

6. Family, school, and community partnerships.

7. Respecting diversity.

8. Assessing progress. 
The research base for the RSA indicators began with the NEGP (1990) Ten Keys to Ready Schools. High/Scope (2006a) researchers then "carefully reviewed" the literature "to further flesh out detailed aspects of each of the RSA dimensions" (p. 11). The next step was an advisory panel that consisted of elementary school principals, teachers, and early childhood researchers to establish the format of the RSA. The High/Scope (2006a) advisory panel also "guided the selection of the content and formatting into measurement indicators" (p. 11). A second focus group of elementary principals, K-2 teachers, and preschool coordinators reviewed a draft of the RSA and made revisions. A second series of focus groups provided further feedback. A final draft instrument that incorporated the recommendations of the focus groups and advisors was piloted. The High/Scope (2006a) review process established a good measure of "face" (p. 11) or content validity. To no other ready school instruments could they compare the RSA.

Definition of the Ready School

In 2001, the W. K. Kellogg Foundation launched a national program to emphasize the importance of community collaboration in supporting school readiness among at-risk children (Berkley, 2009). The initiative was called Supporting Partnerships to Assure Ready Kids (SPARK) and included seven states and the District of Columbia: Florida, Georgia, Hawaii, Mississippi, New Mexico, North Carolina, and Ohio. The goal of SPARK was to promote partnerships between communities, families, and schools so that all would have collective responsibilities for the ready child.

The W. K. Kellogg Foundation selected a team that conducted an initial evaluation of the SPARK initiative and identified nine pathways to ready schools: (a) children succeed in school; (b) welcome atmosphere; (c) leadership; (d) connected to early care and education programs; (e) cultural and linguistic connections to children and 
families; (f) parent involvement; (g) community partnerships; (h) use of assessment results for student progress and school improvement; and (i) quality improvements including professional development (Curtis \& Simons, 2008). The pathways are very similar to the Ten Keys to Ready Schools identified by the NEGP (1990) Ready Schools Resource Group.

Some SPARK participants (e.g., those in North Carolina and Miami, along with a few other states) shifted the readiness conversation to a ready school focus. Given the limited amount of research on the ready school, these state initiatives have been highlighted because they provide information about the ready school.

North Carolina launched a Ready Schools initiative and defined readiness as a puzzle with two pieces - the condition of children when they enter school and the capacity of the school to educate every child (North Carolina Department of Education, 2001). A ready school was identified as a school in which the atmosphere is inviting, values and respects all children and families, and all children succeed. Elementary schools in North Carolina were encouraged to develop a ready school plan using the High/Scope (2006b) RSA that identified eight core areas of school readiness. The RSA is discussed later in this section.

The Miami (Florida) Ready Schools program became a change effort to improve the well-being and educational attainment of children at risk of academic, health, and social difficulties. Some of the challenges schools faced were effective communication about ready schools, transitions from early childhood programs to elementary schools, and addressing gaps and barriers (Golan \& Wechsler, 2008).

Minnesota's Early Childhood Initiative, launched in 2001, was grounded in the belief that all children need a nurturing environment to thrive. State officials noted that 
such an environment was dependent upon the strength of communities. Their plan included building blocks for the ready school: strong families, engaged community members, effective and coordinated early care and education, and early learning opportunities. Minnesota defined a ready school as one whose faculty ease the transition to Kindergarten by building relationships among parents, early care and education providers, and $\mathrm{K}-12$ teachers by promoting parent involvement (Wilder Research for the Minnesota Initiative Foundations, 2007).

Tulare County, California, made a significant investment in its School Readiness Initiative (Brown, Lynch, \& Franke, 2007). The primary goal was for children to be ready for school and schools to be ready for children. In the evaluation report, Brown et al. (2007) suggested four characteristics of ready schools: support transitions to Kindergarten; use valid, reliable assessments to track and improve student learning; provide developmentally appropriate teaching curricula; and engage parents as partners. The Commonwealth of Pennsylvania's initiative, Linking Ready Kids to Ready Schools (Pennsylvania Department of Education, 2008), was developed out of concern that many children were not prepared for school and districts were spending "more time and money to help them catch up" (p. 2). The Pennsylvania model targets transition and parent engagement to improve child readiness and to improve the schools that receive them.

In 2006, Oregon implemented a ready schools project. The NEGP (1990) Ten Keys to Ready Schools was used as a springboard to improve school readiness for children in high poverty areas. 


\section{Researcher's Operational Definition of the Ready School}

The researcher considers several elements important for a ready school. A ready school is one in which leadership and teachers anticipate and prepare for every child, create a welcoming environment for children and their families, have adequate resources to address learning needs, and are driven by the goal that every child will be successful. These elements can be most effective in schools that intentionally align teaching and learning, and preschool to Grade 3.

Ready School Indicators for the Study

Much of the literature, and state and national initiatives, identify the same or similar characteristics of the ready school and support the ready school indicators identified for this study. They are closely aligned to the High/Scope (2006b) RSA and reflect the attributes suggested by the NEGP (1990) Ready Schools Resource Group.

1. Curriculum that is developmentally appropriate, connected to children's cultures, experiences and backgrounds, content-rich, and linked to standards promotes higher learning for young children (Jones, 2005; Katz \& Chard, 2005). A high quality curriculum is thoughtfully planned, comprehensive, and integrated across domains including attention to social and physical development, approaches to learning and cognitive experiences (Bowman et al., 2000; Burke \& Burke, 2005; Raver, 2002; Copple \& Bredecamp, 2009).

2. Families that are actively engaged contribute significantly to school and student achievement beyond their family background and the child's factors (Castro, Bryant, Peisner-Feinberg, Skinner., 2004; Dearing et al., 2008; Graue et al., 2004; Miedel \& Reynolds, 1999). HP/HP schools focus efforts to involve parents as partners in helping students to meet high standards and 
engage families in strategies that are respectful of cultures and perspectives (Barth et al. 1999; Dearing et al., 2008; Education Trust, 1999; Pianta \& Kraft-Sayer, 2003).

3. Teachers are the single most determinate factor of quality and account for greater differences in academic achievement (Burke \& Burke, 2005; DarlingHammond, Wise, \& Klein, 1999; Hamre \& Pianta, 2001; Kagan, 2009; Kannapel \& Clements, 2005; Leithwood, Harris, \& Hopkins, 2008). Effective teachers hold high expectations and make it a priority to know each child and those persons significant to the child, and are good decision makers, adjusting the curriculum and instruction to meet individual learning needs (Ackerman \& Barnett, 2005; Copple \& Bredekamp, 2009; Daniels, 2011; Hamre \& Pianta, 2001; Maxwell \& Clifford, 2004).

4. Assessment is important for learning and helps teachers adapt instruction to children's strengths and weaknesses (Epstein, Schweinhart, DeBruin-Parecki, \& Robin, 2004; Leahy, Lyon, Thompson, \& William, 2005; Maxwell \& Clifford, 2004; Stiggins 2008). On-going, authentic, formative, summative, and culturally sensitive assessment of children's skills and abilities gives educators knowledge of what is or is not working to promote learning (Copple \& Bredecamp, 2009; Epstein et al., 2004; Keilty, LaRocco, \& Casell, 2009; Shepard, Kagan, \& Wurtz, 1998).

5. Leadership is critical for successful schools, especially with at-risk, low-SES students (Brookover \& Schneider, 1975; Edmonds, 1979a, 1979b; Hallinger \& Heck, 1996; Levine, 1986). School leadership is second only to classroom teachers as an influence on student learning and school leaders have the ability 
to influence teaching and learning most powerfully through their influence on staff (Leithwood et al., 2008).

6. Transition planning and implementation is important to assure a seamless process for children. Ready schools foster communication and continuity between early care and education programs and support successful transitions to Kindergarten (Bohan-Baker \& Little, 2002; Early et al., 2001; Halle et al., 2008).

Summary of the Ready School

NCLB (2002) established the need for ready schools, which represents a shift in the school readiness discussion. Many children do not have expected skills and knowledge when they enter Kindergarten, which means that achievement gaps already exist before children start school. Authors of the literature suggested that a ready school provides resources and supports to assure academic success for every child.

The NEGP (1990) Ready Schools Resource Group identified Ten Keys to Ready Schools. Similar characteristics were found in the literature and state initiatives, confirming that ready school indicators are considered important to assure a successful transition to Kindergarten. The ready school indicators in this study are closely aligned to the NEGP characteristics and the High/Scope (2006b) RSA indicators, and the authors of the research literature on effective and high performing schools (discussed next) support them.

In this section, the researcher covered (a) foundation of the ready school concept, (b) definition of a ready school, (c) ready school indicators for the study, and (d) research support for the ready school indicators. 


\section{Effective Schools}

Introduction to the Literature

Although some work occurred around ready schools through the NEGP (1990), little emphasis has been placed on the concept. Therefore, to provide research support for the ready school indicators in this study, the researcher reviewed the literature and research on the features of effective schools and high-performing schools. Effective schools are discussed first.

One of the provisions of the Civil Rights Act of 1964 was equal educational opportunities for all students. That year, Coleman (1966) was commissioned by the U.S. Office of Education to conduct a study of 4,000 schools, 60,000 teachers, and 570,000 students to determine whether differences existed in public education opportunities depending on race, religion, or national origin. Coleman considered variables such as physical facilities, teacher salaries, whether the teacher was Black or White, whether the teacher had an advanced degree, pupil turnover, and so forth. Coleman found that no single characteristic affected student achievement; however, a consistent relationship existed between student SES and student performance. The Coleman Report Equality of Educational Opportunity (Coleman, 1966) indicated that many schools were not making a difference in student achievement, and this news created a vigorous reaction and made researchers scramble to identify schools that did make a significant impact on student achievement. Thus began the era of the Effective Schools Movement (ESM), which spanned 25 years. Although the Coleman Report (Coleman, 1966) outraged many, it motivated researchers to identify schools that had high achievement in spite of demographic challenges (Brookover, Beady, Flood, Scheweizer, \& Wisenbaker, 1979; Levine \& Lezotte, 1990; Teddlie \& Stringfield, 1989). 
It was important to this study to include literature and research on effective schools. One of the key findings of the Coleman Report (Coleman, 1966) was the consistent relationship between low achievement and SES. All of the BSA schools in this study have large numbers of low-SES students. The Effective Schools Research (ESR) and studies discussed next identify certain characteristics that are the same or similar to the ready school success indicators.

During most of the ESM, many were skeptical about using test data to measure student achievement; however, political influence and stakeholder groups forced the use of test data as the ultimate outcome in measuring school effectiveness. Lezotte (1992) referred to this situation as a results-oriented focus on education. During ESM, three debate issues arose concerning: (a) the effectiveness of schools in educating low-SES students, (b) inclusion of students with disabilities, and (c) lack of experimental studies.

Consistent with the Coleman Report (Coleman, 1966), Brookover and Lezotte (1979), Edmonds (1979a, 1979b), Eubanks and Levine (1984), and Goodlad (1984) conducted key research and concluded that too many schools were failing to educate effectively low-SES students. Therefore, literature on effective schools centered on large urban, high-poverty schools that produced higher student performance than was expected to dispel the myth that student outcomes were solely dependent on SES (Brock \& Groth, 2003; Levine, 1986; Levine \& Stark, 1982; Lezotte \& Bancroft, 1985).

Edmonds (1979a, 1979b) considered the pioneer of ESM, along with other researchers were firm in their belief that all students could learn and that, therefore, public schools were responsible for educating all students (Edmonds, 1979a, 1979b; Edmonds, 1981; Hersh et al., 1981; Klitgaard \& Hall, 1974). Other researchers were skeptical about the inclusion of students with disabilities and were concerned that 
effective schools were not designed for all students (Cook, Gerber, \& Semmel, 1997;

Lezotte, 1992). Studies by Levine and Lezotte (1990) and Teddlie and Stringfield (1989) confirmed that effective schools and practices within the schools were inclusive of all students.

Another criticism of the ESM was a lack of experimental or quasi-experimental studies. Although Purkey and Smith (1983) acknowledged the considerable amount of literature regarding effective schools' practices, they argued that it presented a narrow view founded on nonexperimental research. However, despite the methodology used to study effective schools, it was the largest body of research available during that time. Characteristics of Effective Schools

ESR revealed a correlation between high student achievement and certain variables present in the schools that were studied. Edmonds (1979a) along with other researchers (Brookover \& Schneider, 1975; Lezotte, 1992; Ravitch, 1984) suggested that characteristics of an effective school included: (a) outstanding principal and strong leadership, (b) climate of high expectations, (c) orderly but not rigid atmosphere, (d) regular testing program, (e) and emphasis on learning. Cohen (1983) conducted an analysis of effective schools literature and found the interrelatedness of several descriptive variables such as effective classroom practices, management of the instructional program, and a strong culture shared by students and faculty. Hersh et al. (1981) produced a list of characteristics for effective schools, which was complementary of previous work with considerable overlap.

Purkey and Smith (1983) challenged the assumption that differences among school populations did not affect academic achievement. In their analysis of ESR, they included studies that looked at school level data; however, they could not complete the 
quantitative synthesis because of limited, published, empirical data. Purkey and Smith reviewed case studies, surveys, evaluations, and studies of implementation and the process of how schools operated. In spite of their reservations, they found a substantive case emerge of common characteristics of successful schools. Successful schools were more likely to have high expectations for students and provide safe and comfortable environments.

Hawley, Rosenholt, Goodstein, and Hasselbring (1984) conducted a substantial review of studies on schools that were effective in improving student achievement. They examined more than 3,000 studies covering a broad range of topics associated with student achievement and narrowed the focus to identify practices and conditions that correlated to student performance. Hawley et al. concluded that limitations existed to the generalizability of the findings for several reasons. First, most of the research (of the 3,000 studies) was conducted on elementary schools and focused on low-ability and highpoverty students. Second, they found that the description of effective schools' practices were sometimes not easily identified because schools would combine two or more practices and it was difficult to determine which practice had the greatest impact on student achievement. However, in almost every instance, Hawley et al. found that the factor that had the greatest impact on student performance was the teacher. Other consistent findings were that effective schools were characterized by a school climate that recognized student achievement, and these schools had effective teachers. Other practices that had sizable effects, with agreement among most of the studies were that effective schools: (a) maximized learning time; (b) offered interactive teaching; (c) had a positive school climate; (d) had high expectations; (e) involved parents; (f) used student 
information to enhance teaching; and (g) used computers to help teachers facilitate learning.

Creemers (1996) outlined factors from previous ESR and found similar characteristics: (a) strong educational leadership, (b) high expectations for student achievement, (c) safe and orderly environment, and (d) frequent evaluation of student progress. These factors have been supported in the literature (Levine, 1986).

Brock and Groth (2003) argued, in spite of the amount of literature that existed on effective schools, that far too many schools were unable to make the transformation for success. They conducted a collective case study to investigate the change process that occurred when implementing school reform because they believed that the research had not adequately examined the process of change. Their sample included 54 schools, urban and rural, with varying levels of poverty (29-99\%), student mobility rates (33-44\%), English language learners (21-90\%), and single-parent households (19-60\%). All of the schools in the study were participating in an initiative called Highly Impacted Schools, a state-funded program to improve student achievement. Over the course of 4 years, Brock and Groth visited schools to investigate how they changed to become more effective. The school visits included interviews with principals and key staff, reviews of school plans, and classroom observations. They also considered evaluation data from the HIS project. Their findings revealed differences in how schools approached and implemented the process of change, regardless of school demographics. Schools where the administrator, faculty, and staff perceived or expected real opportunities to improve academic achievement were able to transform their school for greater student impact than schools whose staff and administrators perceived very little hope for increasing student learning. 
Essentially, when staff had high expectations the outcome was higher student achievement.

Summary of Effective Schools

In the middle to late 1960s, the Coleman Report (Coleman, 1966) challenged schools to demonstrate their effectiveness, especially for at-risk students, which began the era of the ESM. As a result, ESR clearly revealed similar characteristics among schools that had high student achievement in spite of demographic challenges. Those characteristics were strong leadership, high expectations, regular student assessment, and effective teachers.

Research on effective schools adds a meaningful lens to the concept of the ready school. It emphasizes the need for schools to be prepared for children, and that schools with high numbers of low-SES students (e.g., BSA schools in this study) can be successful and students can achieve at high levels.

In this section, the researcher (a) introduced the literature and research on effective schools and (b) characterized effective schools. A review of the literature and research on high performing schools is presented next.

\section{High Performing Schools}

Introduction to the Literature

In the literature, high-performing schools are defined as schools that have high poverty (i.e., are HP/HP), address achievement gap issues, and produce high levels of student achievement (Manset et al. 2000; Haycock et al. 1999). Research on high performing schools is an extension of the ESM. In fact, the literature on high performing schools uses research by Lezotte (1992) and Edmonds (1979 a, 1981), considered 
pioneers of the ESM, to inform the development of characteristics of high performing schools (Shannon \& Bylsma, 2007).

Poverty and race are often considered two of the strongest predictors of a school's performance; however, evidence from schools across the Nation has defied this fact, for the students have achieved at high levels and have closed gaps in spite of challenges and barriers (Archer, 2002; Cole-Henderson, 2000; Datnow \& Stringfield, 2000; Masumoto \& Brown-Welty, 2009). Researchers in the literature suggested that certain characteristics were present in high-performing schools.

Key Features of High Performing Schools

The Education Trust (1999) conducted a survey of SEAs to identify schools that were high performing and had FRL student populations over 50\%. They identified 366 schools that represented urban and rural, as well as every ethnicity present at the time of the study. The common practices among the schools were that they (a) used state standards to design curriculum and instruction, (b) increased instruction time in reading and mathematics, (c) devoted large amount of funds to professional development, (d) monitored student progress, (e) focused on and involved parents, (f) and had state and district accountability systems in place including consequences for staff (Barth et al., 1999).

Manset et al. (2000) conducted a study on HP/HP schools in Wisconsin and found they had similar characteristics: the leadership was purposeful, teachers used the data to make decisions, and teachers had high expectations for all students. The professional development in the HP/HP schools included peer coaching and mentoring, and provided opportunities for staff interaction. Curriculum and instruction included projects-based learning that was aligned to state standards and driven by local and state assessment 
results. The structure of the schools included small class size and alternative support programs. Although none of the schools had every one of these characteristics, each school had more than one.

Kentucky also commissioned a study on high-performing and low-performing schools to determine whether certain practices had been implemented in high-performing schools that affected student scores on the state assessment. In October 2000, the KDE contracted with the University of Kentucky to evaluate the characteristics of the ungraded primary program in reference to school performance (McCormick, 2003). In Kentucky, the primary program was created under the KERA (1990) and is considered the part of elementary school beginning with Kindergarten until the child is ready to enter Grade 4 . The primary program requires the implementation of seven critical attributes: continuous progress, developmentally appropriate practices, authentic assessment, multiage and multiability grouping, qualitative reporting, professional teamwork, and positive parent involvement. McCormick (2003), the principal investigator, attempted to answer the question, "What types of programs, supports and environments best facilitate high performance in Kentucky's (K-3) primary classrooms?” (p. 5). McCormick identified seven strands for investigation: (a) instructional practices, (b) assessment, (c) multiage and multiability grouping, (d) professional teamwork and development, (e) family involvement, (f) program transition, and (g) leadership. The sample included 19 highperforming, 15 improving, and 13 low-performing schools according to Grade 4 scores on the Kentucky Core Content Test. The research team used mixed methodology to collect qualitative, quantitative, and survey data for the investigation. The team members found support for the effectiveness of developmentally appropriate instructional practices in high-performing schools. The $\mathrm{K}-3$ primary programs implementing this practice were 
described as having classrooms in which children were meaningfully engaged in learning activities, used hands-on materials, and actively constructed their own knowledge. No other significant differences were found among the three groups of schools.

In 2002, school improvement specialists in the State of Washington Office of the Superintendent of Public Instruction reviewed more than 20 studies to investigate the characteristics of high-performing schools. They selected studies that focused on high achievement as measured by standardized tests in demographically challenged schools. Each study was analyzed to determine the characteristics that were found most often. Nine characteristics were associated with high performing schools:

1. Clear and shared focus.

2. High standards and expectations for all students.

3. Effective leadership.

4. High levels of collaboration and communication.

5. Curriculum, instruction, and assessment aligned to state standards.

6. Frequent monitoring.

7. Focused professional development.

8. Supportive learning environment.

9. High levels of family and community involvement.

The Commonwealth of Virginia also investigated the differences between highand low-performing schools. Members of the General Assembly of Virginia were concerned about the large gap between the highest and lowest performing schools and requested a study on practices that were implemented within the schools (Christie, 2004). The researchers examined Virginia schools that had achieved high levels of success on the state assessment in spite of challenges such as high poverty, lack of parental support, 
lack of academic preparation, and lack of student motivation. The final report presented findings similar to other studies. Overall, nine practices were used in high performing schools:

1. Strong principal leadership.

2. Environment conducive to learning.

3. Effective teaching staff.

4. Data-driven assessment of student weaknesses and teacher effectiveness.

5. Curriculum alignment and resources.

6. Differentiation in teaching to meet learning styles and needs.

7. Academic remediation.

8. Teamwork, collaboration, and vertical integration.

9. Structure and intensity of the school day.

McGee (2004) examined existing research on HP/HP schools and summarized commonalities from several lists of characteristics. McGee suggested that the research clearly pointed to high-performing schools as schools that had leaders who established a culture of high expectations, placed emphasis on early literacy and academic learning during and after the school day, used school-wide data, and involved parents. Using this information, McGee developed a research framework to study HP/HP schools in the State of Illinois called Golden Spike schools. The sample of 59 schools was considered successful according to the state assessment data. Along with student scores, the methodology included interview data that was validated by on-site observations. The interviews, observations, and student data revealed commonalities for more than $90 \%$ of the schools. McGee found that high-performing schools had (a) strong, visible leaders who advocated for high student standards; (b) an environment for early literacy; 
(c) talented, hard-working teachers who believed that every child could and would learn, and made the most of academic learning time; and (d) extensive parent involvement with clear expectations.

According to Kannapel and Clements (2005), nearly all of the lowest-performing schools in the country were also high-poverty schools. They conducted a study of HP/HP schools in Kentucky to demonstrate that a student's background "does not have to determine achievement results" (p. 2). They sought to identify the common characteristics that contributed to student and school success in HP/HP schools. Kannapel and Clements (2005) selected eight Kentucky schools that had reached 80 (of 140) on the state accountability index, had FRL populations of at least 50\%, were narrowing the achievement gap between low- and middle-income students, and had a pattern of continuous progress on the state test. They used the Kentucky scholastic audit process and interviewed audit team members for reliability purposes. The scholastic audit was an on-site, intensive review of persistently low-performing schools in the areas of leadership, curriculum, instruction, assessment, and school climate. The process included a review of demographic data, school scores on the state assessment, and interviews with staff, students, and parents. Kannapel and Clements found seven common characteristics or practices in HP/HP schools:

1. High expectations communicated from the principal to staff and staff to students, with a strong belief that students could achieve and the faculty had the ability to make that happen.

2. Caring and nurturing atmosphere that supported relationships among and between adults and students.

3. Strong focus on academics, instruction, and student learning. 
4. Regular assessment of student progress to plan or change instruction to meet student needs.

5. Shared leadership to allow faculty and staff to help make decisions.

6. Data analyzed by staff to meet student needs.

7. Carefully and intentionally recruited teachers. Their study further confirmed common characteristics of high performing schools.

The Appalachia Educational Laboratory at Edvantia (AEL; 2005) conducted a case study of the characteristics of six high-performing schools in Tennessee to determine whether consistency existed in characteristics that had been identified in other studies, including that of Kannapel and Clements (2005). AEL (2005) studied two elementary schools, two middle schools, and two high schools that had been selected from a group of high-performing schools according to mathematics and language arts indicators. The AEL scores were used to select the high schools. AEL researchers reviewed the literature to create a matrix design. They confirmed that no single characteristic produced high levels of student achievement, but seven characteristics were identified as key features of high performing schools:

1. Collaboration and teamwork.

2. Purposeful use of student assessment.

3. Effective teaching.

4. Instructional and shared leadership.

5. Aligned and balanced curriculum.

6. Instructional time maximized.

7. Culture of high expectations. 
The methodology included interviews, a battery of surveys, and reviews of school documents. AEL (2005) captured the findings within a consolidated statement that high performing schools were "characterized by dedicated, hard-working teachers implementing curricula described as being aligned with state standards and doing so within school cultures exhibiting high expectations for student/teacher performance" (p. 49).

Summary of High Performing Schools

Although no one characteristic contributed to school performance, AEL (2005) suggested through its research on high-performing schools that several common characteristics did exist especially in HP/HP schools. AEL's research supports and confirms that schools have the potential to ensure that students achieve at high levels despite challenges such as poverty that characterize BSA schools in this researcher's study. The most common characteristics of high-performing schools that the researcher identified through the literature were (a) effective leadership, (b) high expectations, (c) effective teaching, curricula aligned to state standards, (d) using assessment data, and (e) parent involvement, all of which are similar characteristics of effective schools and support the ready school indicators for this study. Although many of the HP/HP studies include those in middle schools and high schools, the practices can be generalized to any school level.

In this section, the researcher provided an introduction of the literature on highperforming schools, and identified key features and characteristics. In the next and final section of this chapter, the researcher provides a comprehensive framework of the ready child and the ready school, including research support for the indicators and justification for the research questions. 


\section{Conceptual Framework of the Study}

The belief is well established that children have varying skills and abilities, and that for many of them the achievement gap occurs when they enter Kindergarten.

Although high-quality preschool programs can make a difference for some children, schools have a responsibility to prepare for every child. Both ready child and ready school concepts are important if the goal will be high achievement to ensure college and career readiness.

The researcher makes some assumptions about the schools in this study as noted in Figure 2.1. The researcher expects that pre-existing factors (e.g., standards, expectations, and a school's vision and mission) will influence educator perceptions of the ready child and the ready school. Mediating factors of school level performance (ASA and BSA) and role groups (i.e., principals, Kindergarten teachers, and preschool teachers) might affect educators' understanding of the ready child and the ready school. A contrast might also exist between educator responses from schools with ASA scores and schools with BSA scores such that one could draw conclusions that correlate certain ready child and ready school indicators and ready school practices to higher student achievement. Figure 2.1 is a visual depiction of the conceptual framework of this study.

\begin{tabular}{|c|c|c|}
\hline Pre-Existing Factors & Mediating Factors & Attitudinal Outcomes \\
\hline $\begin{array}{l}\text { Standards and } \\
\text { expectations for the } \\
\text { ready child } \\
\text { Standards and } \\
\text { expectations for the } \\
\text { ready school } \\
\text { Vision and mission of } \\
\text { the school }\end{array}$ & $\begin{array}{l}\text { Level of } \\
\text { achievement of ASA } \\
\text { and BSA respondent } \\
\text { schools } \\
\text { Respondent role } \\
\text { group (principal, } \\
\text { Kindergarten } \\
\text { teacher, preschool } \\
\text { teacher) }\end{array}$ & $\begin{array}{l}\text { Shared understanding } \\
\text { of the ready child } \\
\text { Shared understanding } \\
\text { of the ready school } \\
\text { Perceptions of } \\
\text { implementation of } \\
\text { ready school practices }\end{array}$ \\
\hline
\end{tabular}


Figure 2.1. Conceptual framework for factors influencing understanding of Ready Child and Ready School success indicators and implementation of Ready School practices.

\section{Research Questions and Justification}

Although some studies address the ready child and differences in rankings between education professionals regarding success indicators, no studies were found in the literature that addressed both the ready child and the ready school. In addition, no studies were found that addressed the implementation of the ready school practices that the authors in the literature did suggest and that the NEGP (1990) recommended as important for student achievement. Therefore, the researcher expects that the results of this study will bring about greater focus and understanding of the ready child and the ready school, and of their importance to early school success that can later lead to student achievement in the higher grade levels.

The following research questions were addressed through a survey administered to Kentucky elementary principals, Kindergarten teachers, and preschool teachers whose Grade 4 reading and mathematics scores on the 2011-2012 K-PREP were BSA or ASA.

1. Do differences exist in the educator rankings of ready child indicators when comparing

a. Role groups (principals, Kindergarten teachers, and preschool teachers) across school performance levels (BSA or ASA); and

b. Combined educator sample across school performance levels?

2. Do differences exist in educator rankings of ready school indicators when comparing

a. Role groups (principals, Kindergarten teachers, and preschool teachers) across school performance levels (BSA or ASA); and 
b. Combined educator sample across school performance levels?

3. Do differences exist when

a. Comparing BSA and ASA educator ratings of ready school practices; and

b. Correlating ratings of ready school practices to rankings of ready child and ready school indicators between BSA and ASA educators and combined role groups?

Why Is It Important to Get Answers to These Questions?

It is important and essential to know whether differences in perceptions exist between BSA and ASA educators regarding their rankings of ready child and ready school indicators because they might have implications for school practices and priorities. For example, suppose ASA educators rank the ready school indicator assessment higher than BSA educators rank it. This difference in ranking would likely indicate that educators in high-performing schools consider assessment an important feature of their instructional planning efforts. The implication might be that BSA educators should consider assessment to serve better the needs of their student population. The researcher's study is not an experimental study; therefore, it would not be possible to definitely state that putting a high priority on any indicator would produce high-performing students and schools. However, it would be important to note whether such a contrast exists between BSA and ASA schools because it might indicate philosophical and policy differences that could help stimulate the thinking of BSA educators regarding how best to improve practices.

The research questions also address whether differences in perceptions exist between BSA and ASA educators regarding how they rank ready child and ready school 
indicators. Again, potential benefits can result from comparing and contrasting role groups. Suppose that school principals have a different order of ranking for ready child indicators than both preschool and Kindergarten teachers. Knowing such differences exist is important for successful improvement planning and collaboration because school improvement is best accomplished when staff has a shared understanding of educational priorities and practices. At the very least, differences in perception should be discussed and analyzed prior to improvement planning so that school leaders and teachers are "on the same page."

It is also important and useful for several reasons to know whether a relationship exists between educator rankings of ready child and ready school indicators and their ratings of ready school practices. The most obvious reason is to determine whether positive relationships exist and what the strength of such relationships might be. One might expect that all relationships would be positive, that is, that the ranking of the importance of curriculum would be related to its level of implementation. For example, if a respondent ranked curriculum positively, aspects of the indicator would be highly implemented. However, suppose that no positive relationship exists between an indicator ranking and an implementation rating. Such a lack would mean that, regardless of whether an indicator were ranked high or low, it might be implemented as either high or low. Such a situation would indicate that a disconnection existed between the perceived importance of an indicator and whether steps had been taken to accomplish school activities that ought to represent the level of implementation. The lack of a positive relationship between indicator ranking and implementation rating might suggest the need for future inquiry and conversations among school staff to determine which characteristics of the indicator are problematic. 
Regarding published research studies in peer-reviewed journals, the knowledge base is very limited on the topic of what educators consider a ready child or a ready school. This limitation is especially true regarding research on the ready school, which has received less attention than the concept of the ready child. The researcher hopes that this study will contribute to a vigorous national dialogue regarding the characteristics that educators believe describe a ready school. The researcher's sampling plan is purposeful; is designed to sample both BSA and ASA schools; explores different role groups within the schools; and will obtain informative data for legislators, SEAs, superintendents, and central office resource staff, school leaders, and teachers who seek to understand all educational environments—-the successful and the less successful.

\section{Summary of the Chapter}

The ready child is multidimensional. Most children are ready to learn; however, achievement gaps already exist for many of them when they enter Kindergarten. The ready school is important to the ready child to provide resources and supports to ensure that every student has opportunities for successful learning experiences.

The authors of literature and research on the ready child have suggested common indicators of child readiness for school. They have agreed that the focus should be on the whole child and should include social, emotional, and health domains as well as cognitive and academic skills, as the NEGP (1990) Readiness Resource Group has defined them.

Nevertheless, the literature on the ready school is limited. The NEGP Ready Schools Resource Group provides much of the information and identifies the dimensions of ready school characteristics. State initiatives, High/Scope (2006), and other researchers on effective and high-performing schools have provided further support for the ready school and have identified common characteristics of the ready school, including 
effective leadership, high-quality teachers, continuous assessment, and culturally relevant curriculum.

In the final section of this chapter, the researcher connected the ready child and the ready school within a conceptual framework and included the justification for the research questions. Chapter III includes (a) method and design, (b) study limitations, (c) data collection process, and (d) data analysis. 


\title{
CHAPTER III \\ METHODOLOGY
}

\author{
Introduction
}

In an era of rigorous common core standards, this study is timely to ensure college and career readiness for every student, for building the foundation to achieve this goal must begin early. Although the NEGP (1990) has defined the ready child and the ready school, most studies have been focused only on the ready child with little literature written on the ready school. Therefore, in this study, the researcher has connected the two constructs to achieve greater outcomes for children entering school for the first time.

Chapter III focuses on the method and design of the study, the data collection process, and the data analysis. Also included in Chapter III is the development and validation process for the Ready Child, Ready School Survey.

\section{Design}

The intention of this study was to investigate whether differences existed in perceptions about ready child and ready school indicators and the implementation of ready school practices between Kentucky educators working in successful schools (ASA) and Kentucky educators working in less successful schools (BSA). A nonexperimental, quantitative design was employed with cross-sectional data analysis of educator perceptions collected through a survey. The analytical procedures included correlational analyses and nonparametric statistical tests. 
The research design was appropriate because an experimental study of child and school readiness was not possible. Such a study would require national and statewide understanding and adoption of ready child and ready school indicators with clear and measurable objectives and a treatment program would have to be developed and implemented over time to measure effectiveness. Although the NEGP (1990) defined ready school, a tool had not been developed to evaluate the implementation of ready school practices; therefore, using a survey was appropriate to collect educator perceptions about both the ready child and the ready school.

According to Sallant and Dillman (1994), survey research can be a powerful "scientific tool for gathering accurate information" (p. 9). Bandura (1977) suggested that one's beliefs (perceptions of self-efficacy) are predictive of one's behavior. In education, teacher efficacy is related to student academic performance (Fantuzzo, Perlman, Sproul, Minney, \& Perry, 2012; Guo, Connor, Yang, Roehrig, \& Morrison, 2012). Teachers with high efficacy tend to persist with struggling students and try a variety of instructional strategies to promote student learning (Guskey \& Passaro, 1994; Allinder, 1994). Research Ethics and Institutional Review Board Process

Theoretically, survey research poses little to no risk to participants in instances when responses are deidentified and the content does not elicit personal or emotional responses (Salant \& Dillman, 1994). This study posed minimum risks to participants because precautions were taken to ensure confidentiality by using SurveyMonkey, an online, data-collection software for survey data. (See fuller description of this program later in this chapter). Data were only available to the principal investigator. The participants were requested individually to respond to questions on a survey and their responses were combined with other responses, which assured confidentiality. The 
participants had several opportunities to opt out of the study, even after they had agreed to participate and received the survey. The benefits to participate in the study outweighed the risks. The survey provided an opportunity for participants to acquire new knowledge of child and school readiness. The participants learned about indicators and practices that are associated with academic outcomes for young children. In general, society will benefit from the researcher's study because it contributes new research about the ready child and the ready school together. Application was made to the Institutional Review Board at the University of Louisville, Kentucky, including the use of SurveyMonkey. Approval was granted.

Research Setting

It was desirable to conduct this study in Kentucky because the state has been a forerunner in educational reform since 1989 when the courts ruled on Rose v. Council, finding that public school financing was unconstitutional, which led to massive reform across all areas, early childhood included. Also under several governorships, Kentucky has been committed to improving early care and education programs especially for young children from low-SES families. In 2013, for the first time, after piloting a statewide common school readiness assessment, all children entering Kentucky public schools were assessed. Almost half (49\%) of the Kindergarten students were considered ready. Given the poverty level of Kentucky's students, the eligibility of $55 \%$ of students for FRL, and the research discussed in Chapter II correlating low-SES to low achievement, the percentage of children ready for Kindergarten was an impressive first step. Therefore, Kentucky was an ideal setting for this study. 
Sample

Kentucky is primarily a rural state with 1,233 schools in 174 school districts. The elementary schools represent a majority of the schools at $60 \%$ or 740 schools.

A purposeful selection strategy was used for this study because the intent was to select high-scoring elementary schools and low-scoring elementary schools, using the 2011-2012 K-PREP. The goal was to determine whether educators in successful schools think differently (perceptions of ready child and ready school indicators) and do something differently (implementation of ready school practices) that affected student scores on the statewide assessment.

Step 1 in the sample selection was to develop two lists: schools whose 2011-2012 K-PREP Grade 4 reading and mathematics scores were BSA (unsuccessful) and schools whose K-PREP Grade 4 reading and mathematics scores were ASA (successful). Step 2 was to confirm that schools in each list had a preschool program and to eliminate from the appropriate list those that did not have a preschool program, for not all elementary schools in Kentucky have a preschool or Head Start program. It was important to collect responses from educators (principals, Kindergarten, and preschool teachers) who played key roles in child readiness (children entering school for the first time) and school readiness (schools being prepared for every child entering Kindergarten). A comparison of their perceptions would determine whether inconsistencies existed between principals, Kindergarten teachers, and preschool teachers that could affect children's early school experiences. Bandura (1977) suggested that educators' perception of themselves and their involvement in teaching and learning affects their effort and persistence.

After the first screening to ensure that potential sample schools had a preschool program, Step 3 was to generate two lists that represented 81 ASA elementary schools 
and 92 BSA elementary schools for a total of 173 schools. An initial letter was sent to principals at the schools to request the voluntary participation of their staff in the Ready Child, Ready School Survey. After receiving agreement from the principals of 165 schools, Step 4 was to send letters to the preschool and Kindergarten teachers in the respective schools.

Step 5 was to follow up with messages and phone calls, which resulted in a sample of 105 schools (60\% of the 173 elementary schools), representing 185 educators (principals, Kindergarten teachers, and preschool teachers). The sample included 44 BSA schools with K-PREP scores ranging between 16.2-30.9 and 61 ASA schools with scores between 54.2-82.7. The 2011-2012 K-PREP state average was 44.3. The actual numbers and roles of the participants are discussed further in Chapter IV.

Instrumentation

The literature and research on the construct of the ready school was limited. Although Kentucky has defined the ready child and has implemented a common, statewide, school readiness assessment, a state plan for children entering Kindergarten had not been developed.

Several survey instruments were reviewed. The High/Scope (2006b) RSA was considered; however, it did not meet the needs of this study. The RSA has a different purpose and is used as a self-assessment, planning, and improvement tool to help schools prepare for incoming Kindergarteners. Researchers who use the RSA only assume that participants have knowledge of ready schools and want to improve practices. However, the researcher required for this study a tool that assessed both the ready child and the ready school. 
SurveyMonkey sample surveys were reviewed, but none was found to be appropriate to the topic. Other surveys that were related to the topic (e.g., those developed by Perez [2005] and Zuckerman \& Halfon [2003]) were considered; however, they were limited to the ready child and the skills the ready child had upon entry to Kindergarten.

Costenbader, Rohrer, and Difonzo (2000) developed an 80-item school readiness survey, but it, too, had a ready child focus and too many items. Salant and Dillman (1994) suggested that good surveys require very little time to complete and do not pose a burden to respondents. A change in any of the survey instruments that were reviewed (to adapt the survey to the research questions of this study) would have compromised the validity of the instrument.

The researcher sought to consider perceptions of both child and school readiness; therefore, the decision was made to develop a survey—supported by the literature and research - that would more appropriately address the purpose of the study. The purpose was to determine whether differences existed in perceptions of child and school readiness indicators and in implementing ready school practices between Kentucky educators in unsuccessful (BSA) and successful (ASA) elementary schools that might have affected student scores on the K-PREP assessment. Development of the Ready Child, Ready School Survey

Content validation, the method used to confirm the degree to which "a test appropriately represents the content it is intended to measure" (Lawse, 1975, p. 563), was employed. The process included several layers to validate that the content of the Ready Child, Ready School Survey corresponded to the research questions. 
The Version 1 of the survey included two parts—ready child and ready school indicators that would be ranked by participants. At the time, the researcher felt this information would be sufficient to determine whether differences existed between three groups of educators from unsuccessful (BSA) and successful (ASA) schools. Later an expert panel determined that Version 1 of the survey did not produce enough information for desired outcomes, especially about the ready school.

In spring 2010, as an initial pilot, the researcher administered Version 1 of the survey to 42 early childhood teachers, coordinators, and directors. The researcher presented at a statewide early childhood conference and shared this study. The session participants were asked to review the survey instrument and provide feedback. Version 1 contained only two sections: one about ranking the ready child success indicators and the other about ranking the ready school success indicators. The early childhood group provided feedback and several changes were made for clarification. With the changes incorporated, the revised Version 2 short form (two sections) was reviewed by 82 staff in the Office of Teaching and Learning at the KDE in the fall of 2010. Their educational experiences included early childhood education, elementary education, middle school and high school teaching, gifted and talented instruction, special education, school health and nutrition programs, core content, and college and career readiness. Their suggestions were (a) to produce clearer directions for completing the survey; and (b) to develop further the definitions of the ready child and ready school indicators. The directions for completing the survey were revised and the ready child and ready school indicators were defined. Next, the survey was sent to an expert panel. The expert panel consisted of 10 individuals: four early childhood professors and researchers, one early childhood research manager for a national organization, two research analysts for a regional laboratory 
(preschool to high school education), two principal leaders and coaches, and a university professor and researcher of education.

The role of the expert panel was to review the survey to ensure that it matched the research questions and goals of the study and to examine the consistency and content of the survey tool. Using an expert panel is a widely acceptable practice in developing tests (surveys) to determine whether the items are essential and actually measure what they are supposed to measure (Lawse, 1975; Slavin, 2007). Warren (2008) did something similar in his study by developing a survey to gather perceptions of university faculty regarding the merger of Kentucky's community, vocational, and technical colleges. Warren conducted a thorough review of the literature, developed a survey, and used an expert panel to validate the instrument.

The expert panel was divided into two groups. The first half reviewed the draft survey and, using their recommendations, the researcher added a third section about ready school practices, which included descriptive terms about each ready school indicator to help participants determine the level at which each one was implemented at his or her school. Research support for the descriptions of ready school practices was discussed in Chapter II. The revised draft was sent to the remaining panel members (second group) and a few edits were made to produce the final product.

Version 1 of the Ready Child, Ready School Survey and the final version differed in two ways. The major difference was the addition of Section III on ready school practices.

The second difference was the addition of open-ended questions about the ready child and the ready school that were added to Sections I and II in response to proposal 
committee recommendations. A copy of the Ready Child, Ready School Survey is found in Appendix A.

Survey Description

In Section I of the final survey, respondents were requested to rank order on a scale of 1 (extremely important) to 5 (least important) regarding the perceived importance of ready child indicators that they believed were essential for school success. Next, they completed an open-ended question to describe what they believed was the one most important factor that a child must have to be successful upon entering Kindergarten. The answers to this question determined whether participants perceived that any ready child factors were important that were not already included or embedded in the ready child indicators in the survey. The ready child indicators were taken directly from Kentucky's definition for school readiness, which are also the dimensions from the NEGP (1990). Five ready child indicators were used: (a) approaches to learning, (b) health and physical well-being, (c) language and communication, (d) social and emotional development, and (e) cognition and general knowledge.

Section II required the respondents to rank six ready school indicators on a scale of 1 (most important) to 6 (least important). Similar to Section I, in Section II, respondents also completed an open-ended question to describe one change they would make for their schools to "be more successful." In their responses to this question, it was important to know whether they identified changes that were not one of the ready school indicators or not a practice that was already embedded in ready school practices in Section III. The ready school attributes defined by the NEGP (1990) Readiness Resource Group along with the High/Scope (2006b) RSA, and research on effective and high- 
performing schools were used to identify ready school indicators selected for this study. The ready school indicators were (a) curriculum, (b) families, (c) teachers, (d) assessment, (e) leadership, and (f) transition.

In Section III, respondents were asked to identify the level of implementation of ready school practices. The next step was to test the survey tool for reliability.

\section{Test-Retest Correlation}

Test-retest was the method used to determine reliability of the Ready Child, Ready School Survey. Reliability of a measure is critical to assure consistency in producing the same responses or scores from one administration to another (Nunnelly \& Bernstein, 1994).

An elementary school principal was contacted to request participation to pilot the survey. The principal and the Kindergarten teachers (three) and preschool teacher (one) agreed to participate. The surveys were coded to compare individual responses while maintaining confidentiality. The survey was sent to each person, they were completed and returned. Approximately 12 days later, the same survey was sent to the same participants and they were completed and returned. After polling the participants, the average amount of time to complete the survey was 11 minutes.

The analyses revealed consistency of scores between the first administration of the test and the retest. Ranking data had similar median ranks for Time 1 and Time 2 . The items that were ranked as high or low on the first test were ranked nearly the same on the second test (see Tables 3.1 and 3.2).

Section III required the pilot participants to rate the level of implementation of the six ready school indicators. The correlations between the first rating and the second rating ranged from .729 to .992 indicating moderate to high test-retest reliability as noted below 
in Table 3.3. According to Nunnally and Bernstein (1993), a reliability coefficient of .70 or higher is recommended for instruments used in research.

Table 3.1

Test-Retest Ready Child Ranks

\begin{tabular}{lcccccccccc}
\hline & RCa1 & RCa2 & RCh1 & RCh2 & RCl1 & RCl2 & RCs1 & RCs2 & RCc1 & RCc2 \\
\hline N Valid & 5 & 5 & 5 & 5 & 5 & 5 & 5 & 5 & 5 & 5 \\
Missing & 0 & 0 & 0 & 0 & 0 & 0 & 0 & 0 & 0 & 0 \\
Mean & 2.8000 & 3.2000 & 3.0000 & 3.2000 & 1.8000 & 2.0000 & 3.8000 & 3.0000 & 3.6000 & 3.6000 \\
Median & 3.0000 & 3.0000 & 4.0000 & 4.0000 & 1.0000 & 2.0000 & 4.0000 & 3.0000 & 4.0000 & 4.0000 \\
\hline
\end{tabular}

Note. The variable designations (column headings) refer to time 1 and time 2.

Table 3.2

Test-Retest Ready School Ranks

\begin{tabular}{|c|c|c|c|c|c|}
\hline & $\mathrm{RSc1}$ & $\mathrm{RSc} 2$ & RSf1 & RSf2 & RSte1 \\
\hline N Valid & 5 & 5 & 5 & 5 & 5 \\
\hline Missing & 0 & 0 & 0 & 0 & 0 \\
\hline Mean & 3.8000 & 2.4000 & 5.0000 & 5.2000 & 1.6000 \\
\hline Median & 3.0000 & 2.0000 & 5.0000 & 6.0000 & 2.0000 \\
\hline \multicolumn{3}{|c|}{ Table 3.3} & \multicolumn{3}{|c|}{ Note. The variable designations (column headings) } \\
\hline \multicolumn{6}{|c|}{$\begin{array}{l}\text { Summary of Section III Ready School Test-Retest } \\
\text { Correlations (Pearson r) for Average Ratings }\end{array}$} \\
\hline \multicolumn{2}{|c|}{ Rating scale area } & \multicolumn{4}{|c|}{ Test-retest correlation } \\
\hline \multicolumn{2}{|c|}{ Curriculum } & \multicolumn{4}{|c|}{.744} \\
\hline \multicolumn{2}{|l|}{ Families } & \multicolumn{4}{|c|}{.992} \\
\hline \multicolumn{2}{|l|}{ Teachers } & \multicolumn{4}{|c|}{.937} \\
\hline \multicolumn{2}{|c|}{ Assessment } & \multicolumn{4}{|c|}{.944} \\
\hline \multicolumn{2}{|c|}{ Leadership } & \multicolumn{4}{|c|}{.729} \\
\hline
\end{tabular}


Rating scale area

Test-retest correlation

Transition .915

To ensure that participants understood the point value of implementation of ready school practices in Section III, the researcher decided to assign percentages to the terms of Never, Rarely, Sometimes, and so forth (see Table 3.4). For example, before the percentages were added, a participant could have considered that his or her school's implementation of a "comprehensive and aligned curriculum" occurred "often" with a point value of " 3 ": however, by adding the percentage of time (67-99\%), he or she may realize that the practice did not occur "often" and instead "sometimes" which had a percentage range of 34-66\% with a point value of "2." The High/Scope (2006a) RSA "frequency of scale levels" (p. 4) was used as a guide. The percentages and point values of ready school practices are described below.

\section{Table 3.4}

Conversion of Term to Points Using Percentages

\begin{tabular}{lcc}
\hline Term & Percentage & Points \\
\hline $\begin{array}{l}\text { No Basis (to make a } \\
\text { determination) }\end{array}$ & NA & NA \\
Never & 0 & 0 points \\
Rarely & $1-33$ & 1 point \\
Sometimes & $34-66$ & 2 points \\
Often & $67-99$ & 3 points \\
Always & 100 & 4 points \\
\hline
\end{tabular}

It was also important for respondents to understand the distinction between a ready school practice that was implemented Often or $67-99 \%$ and one that was 
implemented Always or $100 \%$ of the time. For example, a ready school practice implemented Often at 67\%, which is the lower end, is much different from a practice that is implemented $100 \%$ or Always.

\section{Study Limitations}

The participants identified for the study were educators; therefore, only their views of the ready child and ready school were considered, even though family involvement is one of the ready school indicators in the survey. Several studies confirmed that parents typically rate academic skills as more important for school readiness than other aspects of readiness (Ackerman \& Barnett, 2005; Duncan et al. 2007; Piotrkowski, Botsko, \& Matthews, 2001). Parents also viewed alphabet recognition, mathematics, and reading as essential for school readiness, whereas teachers were more likely to rate emotional skills and good health of greater importance (Lewitt \& Baker, 1995; Protheroe, 2006). A step that was taken to minimize the adverse effects of educator response to the "family" ready school indicator was to position it closer to the top rather than at or near the bottom of the list to ensure that as much consideration was given to "family" as other indicators. Sallant and Dillman (1994) suggested that survey participants typically pay greater attention to the first items on a list.

Some studies identify school culture and environment as characteristic of effective and high performing schools (Alston, 2004; Brock \& Groth, 2003; Levine \& Lezotte, 1990). School culture and environment was not included as a separate indicator, but was embedded in the ready school descriptions and addressed through teacher practices, curriculum, and leadership.

Some researchers might consider that using the K-PREP state average as a cut score is a limitation for sample selection. Initially the researcher considered the 50 
highest performing schools and the 50 lowest performing schools to create extreme groupings. However, given the design of the study - that it was nonexperimental and would rely on voluntary participation to complete a survey - the numbers would not have been sufficient for data analyses. Earlier in this chapter under the Sample section, the initial pool of schools was 92 BSA schools and 81 ASA schools, but the final respondents represented 44 BSA schools and 61 ASA schools. The decision was made to use a larger spread of scores around the median and emphasize role groups for a sufficient sample size.

Another potential limitation was that this is a nonexperimental study and uses a survey to capture the perceptions of teachers and principals. Some participants could respond in a way they believe is socially acceptable and their responses might not reflect actual practices. However, Bandura (1977) suggested that one's beliefs lead to action; therefore, attitudinal data can have relevance to practice. In addition, an experimental study of the ready child and the ready school was not possible because a treatment program (at the time of this study) did not exist by which one could measure effectiveness of a ready child, ready school program.

\section{Data Collection}

\section{Process}

In an email to principals, Kindergarten teachers, and preschool teachers on March 1, 2013, the study was introduced, participation requested, and confidentiality assured. Four benefits were included in the email to encourage participation:

1. You will help define a "ready school" for Kentucky and the nation.

2. You will have the opportunity to inform $\mathrm{KDE}$ and the nation about ready children and ready schools. No study includes both concepts. 
3. The results of the study might provide you with information about ready child and ready school practices that can promote higher student learning.

4. This is an opportunity to contribute to new research on school readiness.

An email was sent to educators who confirmed their participation to notify them of the upcoming survey and to let them know that their responses would be collected through SurveyMonkey. The survey was administered on March 11, 2013, and concluded on March 25, 2013.

SurveyMonkey was created in 1999 and is a popular, anonymous, Web survey system (Gordon, 2002). It allows the user to create a survey, upload it in the system, and collect responses in real time. SurveyMonkey provides instant reports and can send periodic reminders to participants to respond. It had been used previously to collect information from Kentucky educators, so familiarity with the data collection tool made it efficient and useful.

The participant list was uploaded to SurveyMonkey, which then sent the survey link, individually, to participants via email. Although they had been told the survey would be available for 1 week, it was extended through a second week to allow more educators to respond. Intermittent prompts via emails through SurveyMonkey were sent to those who had not responded. Salant and Dillman (1994) suggested follow up correspondence for a greater response rate.

\section{Data Analysis}

Procedures

In this study, the researcher addresses three research questions that pertain to ready child indicators, ready school indicators, and the implementation of ready school 
practices. The method of ranking the items does not meet the requirements for parametric assumptions; therefore, nonparametric statistical methods were used.

The participants completed the Ready Child, Ready School Survey through SurveyMonkey. The results were produced along with graphic descriptions of the responses. The information was then filtered and exported to Excel files; it was then transferred to the Statistical Package for the Social Sciences program for inferential statistical tests.

\section{Research Question 1}

To address the effects of the independent variables school performance and role groups on the dependent variable ready child indicators, a Mann-Whitney U-Test (Mann \& Whitney, 1947) was performed. This test is one of the well-known, nonparametric significant tests and is used to determine whether a difference exists between two groups and is more robust when comparing sums of ranks (Fay \& Proschan, 2010). School performance has two levels_-BSA and ASA — and three role groups - principal, Kindergarten teacher, and preschool teacher. Research Question 1 addressed the comparison between BSA role group rankings of ready child indicators to each ASA role group rankings of ready child indicators (e.g., BSA principal responses compared to ASA principal responses, and so forth). Then the combined educator sample for each performance level was compared-all of BSA role group ready child rankings were combined and compared to all of the combined ASA role group ready child rankings. The Mann-Whitney U Test (Mann \& Whitney, 1947) was applied to determine any statistical differences. 


\section{Research Question 2}

The procedure for Research Question 2 was the same as Research Question 1, except that it addressed the effects of school performance and role groups on ready school rankings. Rankings of the ready school indicators were compared between BSA and ASA role groups as well as the combined educator responses across performance levels. The same test was applied.

Research Question 3

Research Question 3 had two parts. In Research Question 3a, BSA and ASA ready school ratings were compared. Research Question 3b considered correlations between ratings of ready school practices and rankings of ready child and ready school indicators.

Spearman rank order correlations were calculated that related rankings of ready child indicators and rankings of ready school indicators to average ratings of implementation of ready school indicator practices. Spearman is a nonparametric measure of statistical dependence between variables (Choi, 1977). Spearman rank order correlations assess how well a relationship can be described between variables. For ready school implementation ratings, the average rating was calculated over subareas being rated. For example, Ready School Indicator 1 was curriculum, which had five subareas: (a) comprehensive and aligned, (b) developmentally appropriate, (c) relevant and meaningful, (d) integrated across content areas, and (e) culturally and individually responsive. The respondent had to rate the frequency level of implementation of each subarea. The frequency levels ranged from Never $/ 0 \%$ (0 points) to Always $100 \%$ (4 points). The responses were averaged to yield an overall rating for ready school implementation of curriculum. 


\section{Summary}

In this chapter, the researcher described and supported the methodology used to capture educator perceptions about ready child and ready school success indicators and implementation of ready school practices. The chapter covered (a) research design, (b) setting, (c) sample, (d) ethics, (e) instrumentation, (f) survey development and description, (g) pilot test, (h) study limitations, (i) data collection, and (j) data analysis. Chapter IV provides results and findings of the study. 


\section{CHAPTER IV}

\section{RESULTS}

\section{Introduction}

In this study, the researcher employed a nonexperimental, quantitative design with cross-sectional data analysis of educator perceptions of ready child and ready school indicators and the implementation of ready school practices that were collected through a survey. The analytical procedures included correlational analyses and nonparametric statistical tests.

In this chapter, the reader is reintroduced to the sample including demographic information. Next, the survey instrument is discussed briefly because it was previously discussed in detail in Chapter III, which is followed by a discussion of the findings, and the summary.

\section{Sample}

The sample consisted of 185 educators who included 43 principals, 82 Kindergarten teachers, and 60 preschool teachers. A purposeful selection strategy was implemented to ensure that educators were representative of two groups of schools; according to their Grade 4 reading and mathematics scores on the 2011-2012 K-PREP. Elementary schools with BSA scores and elementary schools with ASA scores were selected. Table 4.1 shows the number of BSA and ASA principals, Kindergarten teachers, and preschool teachers who participated in the study. In general, the number $(n)$ of BSA and ASA participants were fairly even across role groups. 
Table 4.1

Below State Average and Above State Average Study Participants

\begin{tabular}{lcccc}
\hline & \multicolumn{3}{c}{ Educator roles } \\
\cline { 2 - 4 } Performance level & Principal & $\mathrm{K}$ & Pre-K & Total \\
\hline BSA & 21 & 35 & 30 & 86 \\
ASA & 22 & 47 & 30 & 99 \\
Total & 43 & 82 & 60 & 185 \\
\hline Note. ASA=above state average, BSA=below state average, K=Kindergarten.
\end{tabular}

As discussed in Chapter II, several studies revealed correlations between SES and academic performance. The BSA schools represented in this study were 44 and all of them had greater percentages of students eligible for FRL than the state average, most of them with a much higher average (mean=83\%). The 2011-2012 FRL average for Kentucky was $55 \%$.

The ASA schools were 61 and, although $31-51 \%$ had lower FRL rates than the state average, almost half of the ASA schools had FRL rates greater than the state average. Table 4.2 provides FRL rates for BSA and ASA schools.

\section{Table 4.2}

Comparing Free or Reduced Lunch Rates for Below State Average and Above State Average Schools

BSA schools

\begin{tabular}{|c|c|c|c|c|c|}
\hline & $N$ & Minimum & Maximum & Mean & Std. Deviation \\
\hline $\mathrm{FR} / \mathrm{L}$ & 44 & 65 & 96 & 83.16 & 8.405 \\
\hline Valid N & 44 & & & & \\
\hline \multicolumn{6}{|c|}{ ASA schools } \\
\hline & $N$ & Minimum & Maximum & Mean & Std. Deviation \\
\hline
\end{tabular}


FR/L

61

0

90

51.49

19.189

Valid N 61

Note. $F R / L=$ free or reduced lunch.

Other demographic information collected from participants was years of service at their particular school. Table 4.3 provides the responses. It appears that very little difference existed in years of service between BSA and ASA educators. The majority of educators for each group had been at their school for 7 years or less.

\section{Table 4.3}

Years of Service for Below State Average and Above State Average Educators

\begin{tabular}{lccccc}
\hline \multicolumn{4}{c}{ Years of service } \\
\cline { 2 - 5 } & $0-3$ years & $4-7$ years & $8-12$ years & $13+$ years & Total \\
\hline BSA & $27(32 \%)$ & $21(25 \%)$ & $14(16 \%)$ & $23(27 \%)$ & 85 \\
ASA & $32(32 \%)$ & $27(27 \%)$ & $15(15 \%)$ & $25(25 \%)$ & 99 \\
Total & 59 & 48 & 29 & 48 & 184 \\
\hline Note. ASA=above state average, BSA=below state average.
\end{tabular}

Findings

The initial process to analyze the data was to screen for inconsistencies. Data cleaning included eliminating the participants who did not respond to any of the survey questions.

Research Question 1: Ready Child Indicator Rankings

Do differences exist in the educator rankings of ready child indicators when comparing (a) role groups (principals, Kindergarten teachers, and preschool teachers) across school performance levels (BSA or ASA) and (b) combined educator sample (all role groups) across school performance levels? 
In Table 4.4, significant differences were found between BSA and ASA role groups in how they ranked ready child indicators. Differences were found between BSA and ASA (a) principals in how they ranked health and physical well-being,

(b) preschool teachers in how they ranked approaches to learning, and (c) overall role groups in how they ranked approaches to learning.

\section{Table 4.4}

Ready Child Median Rankings Comparing Role Groups and Combined Educator Sample (and whether there was a significant difference based on school performance)

\begin{tabular}{lcccccccc}
\hline & $\begin{array}{c}\text { Principals } \\
\text { median }\end{array}$ & $\begin{array}{c}\text { ASA } \\
\text { BSA }\end{array}$ & $\begin{array}{c}\text { Kindergarten } \\
\text { median }\end{array}$ & $\begin{array}{c}\text { ASA } \\
\text { BSA }\end{array}$ & $\begin{array}{c}\text { Pre-K } \\
\text { median }\end{array}$ & $\begin{array}{c}\text { ASA } \\
\text { BSA }\end{array}$ & $\begin{array}{c}\text { Overall } \\
\text { median }\end{array}$ & $\begin{array}{c}\text { ASA } \\
\text { BSA }\end{array}$ \\
\hline Approaches to learning & 3.0 & no & 2.0 & no & 3.0 & yes & 3.0 & yes \\
$\begin{array}{l}\text { Health and physical well- } \\
\text { being }\end{array}$ & 4.0 & yes & 3.0 & no & 3.0 & no & 3.0 & no \\
$\begin{array}{l}\text { Language and } \\
\text { communication }\end{array}$ & 3.0 & no & 3.0 & no & 2.0 & no & 3.0 & no \\
$\begin{array}{l}\text { Social and emotional } \\
\text { development }\end{array}$ & 2.0 & no & 3.0 & no & 3.0 & no & 3.0 & no \\
$\begin{array}{l}\text { Cognition and general } \\
\text { knowledge }\end{array}$ & 4.0 & no & 4.0 & no & 4.0 & no & 4.0 & no \\
\hline
\end{tabular}

Note. $\mathrm{ASA}=$ above state average, $\mathrm{BSA}=$ below state average, $\mathrm{K}=$ Kindergarten.

Table 4.5 indicates how principals in BSA and ASA schools ranked the ready child indicator health and physical well-being differently, with ASA principals ranking this indicator as more important than BSA principals. Principals in ASA schools ranked health and physical well-being as a median of three out of five in a range of 1 (most important) to 5 (least important) and principals in BSA schools ranked this indicator as a median of five out of five, $\chi^{2}(1)=3.965, p<.05$. 
Table 4.5

Significant Differences Observed for Rankings of Ready Child Indicators

\begin{tabular}{llllllll}
\hline & & $\begin{array}{c}\text { Median across performance } \\
\text { levels }\end{array}$ & $\begin{array}{l}\text { Distribution across } \\
\text { performance level }^{2}\end{array}$ \\
\cline { 3 - 7 } Indicator & Role group & $\chi^{2}$ & df & $p$-value & Mann-Whitney U & $p$-value \\
\hline $\begin{array}{l}\text { Health and physical } \\
\text { well-being }\end{array}$ & Principals & 3.965 & 1 & .046 & - & - \\
Approaches to learning & Pre-K teachers & - & - & - & 519.5 & .015 \\
Approaches to learning & $\begin{array}{l}\text { Combined educator } \\
\text { sample }\end{array}$ & 6.835 & 1 & .009 & $4,133.0$ & .029 \\
\hline
\end{tabular}

${ }^{\mathrm{T}}$ Independent-Samples Median Test

${ }^{2}$ Independent-Samples Mann-Whitney U Test

In Table 4.6, more ASA principals than BSA principals ranked ready child indicator health and physical well-being as important. More than half of the BSA principals ranked the indicator as least important.

Table 4.6

Principal Percentage Rankings of Health and Physical Well-Being

\begin{tabular}{lcccc}
\hline & \multicolumn{2}{c}{ BSA principals $(n=19)$} & \multicolumn{2}{c}{ ASA principals $(n=19)$} \\
\cline { 2 - 5 } Ranking & $n$ & Percent & $n$ & Percent \\
\hline 1 more important & 3 & 15.8 & 3 & 15.8 \\
2 & 1 & 5.3 & 4 & 21.1 \\
3 & 1 & 5.3 & 5 & 26.3 \\
4 & 3 & 15.8 & 3 & 15.8 \\
5 least important & 11 & 57.9 & 4 & 21.1 \\
Total & 19 & 100.0 & 19 & 100.0 \\
\hline Note. ASA=above state average, BSA=below state average.
\end{tabular}

Note. $\mathrm{ASA}=$ above state average, $\mathrm{BSA}=$ below state average.

Approaches to learning differed significantly for preschool teachers in BSA and ASA schools, $\mathrm{U}=519.5, p<.05$. Although their medians did not differ significantly, the percentages in Table 4.7 revealed that more than half of BSA preschool teachers ranked 
ready child approaches to learning important (1 or 2), which was the opposite of ASA preschool teachers. More than half of ASA preschool teachers ranked approaches to learning as the least important indicator of a ready child (4 or 5).

\section{Table 4.7}

Pre-Kindergarten Teacher Rankings of Approaches to Learning

\begin{tabular}{lcccc}
\hline & \multicolumn{2}{c}{ BSA pre-K teachers $(n=28)$} & \multicolumn{2}{c}{ ASA pre-K teachers $(n=27)$} \\
\cline { 2 - 5 } Ranking & $\mathrm{n}$ & Percent & $\mathrm{n}$ & Percent \\
\hline 1 more important & 9 & 32.1 & 2 & 7.4 \\
2 & 6 & 21.4 & 4 & 14.8 \\
3 & 5 & 17.9 & 6 & 22.2 \\
4 & 5 & 17.9 & 10 & 37.0 \\
5 least important & 3 & 10.7 & 5 & 18.5 \\
Total & 28 & 100.0 & 27 & 99.9 \\
\hline
\end{tabular}

Note. $\mathrm{ASA}=$ above state average, $\mathrm{BSA}=$ below state average, $\mathrm{K}=$ Kindergarten.

Overall, educators in BSA schools ranked the ready child approaches to learning as more important than did educators in ASA schools. More ASA educators ranked approaches to learning as least important compared to BSA educators. Table 4.8 provides ranking percentages.

\section{Table 4.8}

Overall Educator Rankings of Approaches to Learning

\begin{tabular}{lcccc}
\hline & \multicolumn{2}{c}{ BSA educators $(n=77)$} & \multicolumn{2}{c}{ ASA educators $(n=89)$} \\
\cline { 2 - 5 } Ranking & $n$ & Percent & $n$ & Percent \\
\hline 1 more important & 24 & 31.1 & 23 & 25.8 \\
2 & 15 & 19.5 & 12 & 13.5 \\
3 & 19 & 24.7 & 14 & 15.7 \\
4 & 13 & 16.9 & 25 & 28.1
\end{tabular}




\begin{tabular}{lcccc}
\hline & \multicolumn{2}{c}{ BSA educators $(n=77)$} & \multicolumn{2}{c}{ ASA educators $(n=89)$} \\
\cline { 2 - 5 } Ranking & $n$ & Percent & $n$ & Percent \\
\hline 5 least important & 6 & 7.8 & 15 & 16.9 \\
\hline Note. ASA $=$ above state average, BSA=below state average.
\end{tabular}

Note. $\mathrm{ASA}=$ above state average, $\mathrm{BSA}=$ below state average.

Research Question 2: Ready School Indicator Rankings

Do differences exist in educator rankings of ready school indicators when comparing (a) role groups (principals, Kindergarten teachers, and preschool teachers) across school performance levels (BSA or ASA) and (b) combined educator sample across school performance levels? In Tables 4.9 and 4.10, a significant difference was found in ranking the transition ready school indicator between BSA and ASA Kindergarten teachers.

\section{Table 4.9}

Ready School Median Rankings Comparing Role Groups and Combined Educator Sample (and whether there is a significant difference based on their school performance level)

\begin{tabular}{lcccccccc}
\hline $\begin{array}{l}\text { Ready school } \\
\text { indicator }\end{array}$ & $\begin{array}{c}\text { Principals } \\
\text { median }\end{array}$ & $\begin{array}{c}\text { ASA } \\
\text { BSA }\end{array}$ & $\begin{array}{c}\text { Kindergarten } \\
\text { median }\end{array}$ & $\begin{array}{c}\text { ASA } \\
\text { BSA }\end{array}$ & $\begin{array}{c}\text { Pre-K } \\
\text { median }\end{array}$ & $\begin{array}{c}\text { ASA } \\
\text { BSA }\end{array}$ & $\begin{array}{c}\text { Overall } \\
\text { median }\end{array}$ & $\begin{array}{c}\text { ASA } \\
\text { BSA }\end{array}$ \\
\hline $\begin{array}{l}\text { Curriculum } \\
\text { Families }\end{array}$ & 4.0 & no & 3.0 & no & 3.0 & no & 3.0 & no \\
Teachers & 2.0 & no & 2.0 & no & 2.0 & no & 2.0 & no \\
Assessment & 4.0 & no & 2.0 & no & 2.0 & no & 2.0 & no \\
Leadership & 3.5 & no & 5.0 & no & 4.0 & no & 4.0 & no \\
Transition & 6.0 & no & 6.0 & yes & 6.0 & no & 6.0 & no \\
\hline
\end{tabular}

Note. $\mathrm{ASA}=$ above state average, $\mathrm{BSA}=$ below state average, $\mathrm{K}=$ Kindergarten.

Table 4.11 pertains to percentages of Kindergarten teacher rankings of the transition ready school practices. Rankings of transition differed significantly between Kindergarten teachers in BSA and ASA schools, $\mathrm{U}=826.0, p<.05$. Although their medians did not differ significantly, the percentages in Table 4.11 demonstrate that 
Kindergarten teachers in BSA schools ranked transition more important in general than Kindergarten teachers in ASA schools. A large majority of ASA Kindergarten teachers (79\%) ranked transition as least important.

\section{Table 4.10}

Significant Differences Observed for Rankings of Ready Child Indicators

\begin{tabular}{|c|c|c|c|c|c|c|}
\hline \multirow[b]{2}{*}{ Indicator } & \multirow[b]{2}{*}{ Role group } & \multicolumn{3}{|c|}{ Median across performance levels ${ }^{1}$} & \multicolumn{2}{|c|}{ Distribution across performance level ${ }^{2}$} \\
\hline & & $\chi^{2}$ & $\mathrm{df}$ & $p$-value & Mann-Whitney U & $p$-value \\
\hline Transition & $\begin{array}{c}\text { Kindergarten } \\
\text { teachers }\end{array}$ & - & - & - & 826.0 & .015 \\
\hline
\end{tabular}

${ }^{\mathrm{T}}$ Independent-Samples Median Test

${ }^{2}$ Independent-Samples Mann-Whitney U Test

Table 4.11

Kindergarten Teacher Ready School Rankings of Transition

\begin{tabular}{lcccc}
\hline & \multicolumn{3}{l}{ BSA Kindergarten teachers $(n=30)$} & ASA Kindergarten teachers $(n=43)$ \\
\cline { 2 - 5 } Ranking & $n$ & percent & $N$ & percent \\
\hline 1 more important & 0 & 0.0 & 2 & 4.7 \\
2 & 2 & 6.7 & 0 & 0.0 \\
3 & 2 & 6.7 & 1 & 2.3 \\
4 & 4 & 13.3 & 2 & 4.7 \\
5 & 7 & 23.3 & 4 & 9.3 \\
6 least important & 15 & 50.0 & 34 & 79.1 \\
\hline
\end{tabular}

Note. ASA=above state average, BSA=below state average.

\section{Ready Child, Ready School Open-Ended Questions}

In Sections I and II of the Ready Child, Ready School Survey, participants responded to questions about "one thing" they would want for every child entering school for the first time (ready child) and "one thing" they would change about their school to be 
more successful (ready school). The majority of participant answers were clustered around general themes.

What was one thing every child needed? The responses about one thing every child needed centered on four themes, not in any particular order: (a) stronger parent involvement, (b) stable home environment, (c) motivated to learn, (d) attended early childhood program, and (e) healthy. Table 4.12 summarizes the responses.

\section{Table 4.12}

One Thing Every Child Needs

\begin{tabular}{lll}
\hline Average & \multicolumn{1}{c}{ Role } & \multicolumn{1}{c}{ Most frequent response } \\
\hline BSA & Principal & Stable home environment \\
BSA & Kindergarten & Stronger parent involvement, child motivated to learn \\
BSA & Preschool & Stable home environment \\
ASA & Principal & Stable home environment \\
ASA & Kindergarten & Stable home environment \\
ASA & Preschool & Stable home environment \\
\hline Note. ASA=above state average, BSA=below state average.
\end{tabular}

In Table 4.13, the most frequent response from BSA principals and preschool teachers was that a stable home environment was most needed. According to BSA Kindergarten teachers, parent involvement and a child's motivation to learn were what children needed most to be ready for school. Educators in ASA schools felt a stable home environment was one thing every child needed.

What was one thing educators would change about their school? Answers to this question centered on four themes: (a) improved parent involvement practices; (b) effective teachers; and (c) more resources such as time, money, technology, smaller class size; and (d) interventions for struggling learners. In Table 4.14, BSA principals and 
preschool teachers agreed they would improve parent involvement practices. BSA

Kindergarten teachers said that they would increase resources. ASA educators agreed that the one thing they would change in their schools was to increase resources.

Table 4.13

One Change to Make the School More Successful

\begin{tabular}{lll}
\hline Average & Role & Most frequent responses \\
\hline BSA & Principal & Parent involvement \\
BSA & Kindergarten & Resources \\
BSA & Preschool & Parent involvement \\
ASA & Principal & Resources \\
ASA & Kindergarten & Resources \\
ASA & Preschool & Resources \\
\hline Note. ASA=above state average, BSA=below state average.
\end{tabular}

Research Question 3

Do differences exist between BSA and ASA educator ratings of ready school practices that were implemented in their schools? Do correlations exist between educator ratings of ready school practices and their rankings of ready child and ready school indicators?

In the first part of Research Question 3, educators rated ready school practices at their schools according to the frequency by which they believed the practices were implemented. The development of the rating scale was discussed in Chapter III. Educators were asked to rate the level of implementation of six ready school practices (curriculum, families, teachers, assessment, leadership, and transition) from Never $=0 \%$ of the time and 0 points to Always $=100 \%$ of the time and 4 points. 
In Tables 4.14 and 4.15, although median ratings did not differ significantly between BSA and ASA educators, in general, ASA educators rated the teacher ready school practices higher than did BSA educators, $\mathrm{U}=519.5, p<.05$.

\section{Table 4.14}

Median Ready School Ratings Comparing Role Groups and Combined Educator Sample (and whether there was a significant difference based on their school performance level)

\begin{tabular}{lcccccccc}
\hline $\begin{array}{l}\text { Ready school } \\
\text { indicator }\end{array}$ & $\begin{array}{c}\text { Principals } \\
\text { median }\end{array}$ & $\begin{array}{c}\text { ASA } \\
\text { BSA }\end{array}$ & $\begin{array}{c}\text { Kindergarten } \\
\text { median }\end{array}$ & $\begin{array}{c}\text { ASA } \\
\text { BSA }\end{array}$ & $\begin{array}{c}\text { Pre-K } \\
\text { median }\end{array}$ & $\begin{array}{c}\text { ASA } \\
\text { BSA }\end{array}$ & $\begin{array}{c}\text { Overall } \\
\text { Median }\end{array}$ & $\begin{array}{c}\text { ASA } \\
\text { BSA }\end{array}$ \\
\hline Curriculum & 3.2 & no & 3.2 & no & 3.4 & no & 3.2 & no \\
Families & 2.8 & no & 2.8 & no & 3.0 & no & 2.8 & no \\
Teachers & 3.2 & no & 3.4 & no & 3.8 & no & 3.4 & yes \\
Assessment & 3.0 & no & 3.0 & no & 3.6 & no & 3.0 & no \\
Leadership & 3.4 & no & 3.2 & no & 3.6 & no & 3.4 & no \\
Transition & 3.0 & no & 2.8 & no & 3.3 & no & 3.0 & no \\
\hline Note. ASA=above state average, BSA=below state average, K=Kindergarten. & & &
\end{tabular}

Table 4.15

Significant Differences Observed for Ratings of Ready School Practices

\begin{tabular}{|c|c|c|c|c|c|c|}
\hline \multirow[b]{2}{*}{ Indicator } & \multirow[b]{2}{*}{ Role group } & \multicolumn{3}{|c|}{ Median across performance levels ${ }^{1}$} & \multicolumn{2}{|c|}{$\begin{array}{c}\text { Distribution across performance } \\
\text { level }^{2}\end{array}$} \\
\hline & & $\chi^{2}$ & $\mathrm{Df}$ & $p$-value & Mann-Whitney U & $p$-value \\
\hline $\begin{array}{l}\text { Teaching } \\
\text { practices }\end{array}$ & Combined educator & - & - & - & 3719.5 & .042 \\
\hline
\end{tabular}

Table 4.16 provides percentages of educator ratings of the teacher ready school practices. The percentage of ASA educators who rated implementation of teacher practices at the highest level (Always implemented this practice 100\% of the time and 4.0) was greater than the percentage of BSA educators. 
Table 4.16

Combined Below State Average and Above State Average

Educator Ratings of Teacher Practices

\begin{tabular}{lcccc}
\hline & \multicolumn{2}{c}{ BSA overall $(n=74)$} & \multicolumn{2}{c}{ ASA overall $(n=85)$} \\
\cline { 2 - 5 } Rating $^{1}$ & $n$ & Percent & $n$ & Percent \\
\hline $0.0-0.9$ & 0 & $0.0 \%$ & 0 & $0.0 \%$ \\
$1.0-1.9$ & 1 & $1.4 \%$ & 0 & $0.0 \%$ \\
$2.0-2.9$ & 7 & $9.5 \%$ & 7 & $8.2 \%$ \\
$3.0-3.9$ & 48 & $64.9 \%$ & 46 & $54.1 \%$ \\
4.0 & 18 & $24.3 \%$ & 32 & $37.6 \%$ \\
\hline
\end{tabular}

Note. ASA=above state average, BSA=below state average.

${ }^{1} 0=0 \%, 1=1-33 \%, 2=34-66 \%, 3=67-99 \%, 4=100 \%$

The data analyses for the second part of Research Question 3 considered correlations between educator rankings of ready child and ready school indicators compared to their ratings of ready school practices (frequency of implementation). The findings are noted in the next several tables for each role group beginning with BSA and ASA principals in Table 4.17.

In Table 4.17, BSA principals who ranked the ready child indicator social and emotional development as important also implemented Curriculum, $\rho=.493, p<.01$; Teachers, $\rho=-.607, p<.01$; Assessment, $\rho=.508, p<.01$; and Leadership, $\rho=.487, p<.01$ ready school practices at high levels. No significant finding for ASA principals with respect to ready child Social Emotional Development and ready school practices. 


\section{Table 4.17}

Correlations Between Above State Average and Below State Average Principal Responses on Ready Child Indicator Rankings (1-5) and Ready School Practices $(6-11)$

\begin{tabular}{|c|c|c|c|c|c|c|c|c|c|c|c|}
\hline \multirow{2}{*}{$\begin{array}{l}\text { Ready child indicator rankings and } \\
\text { ready school practices }\end{array}$} & \multicolumn{6}{|c|}{ ASA } & \multicolumn{5}{|c|}{ BSA } \\
\hline & 1 & 2 & 3 & 4 & 5 & 6 & 7 & 8 & 9 & 10 & 11 \\
\hline 1. Approach to learning & - & -.063 & -.087 & -.376 & -.143 & -.320 & -.093 & -.140 & -.391 & .039 & -.308 \\
\hline 2. Health and physical well being & -.275 & - & $-.551^{*}$ & -.046 & -.248 & .328 & .327 & .353 & .305 & .265 & .249 \\
\hline 3. Language and communication & -.447 & -.146 & - & -.012 & -.314 & -.032 & -.431 & -.293 & -.003 & -.054 & -.182 \\
\hline 4. Social and emotional development & $-.682 * *$ & .150 & .206 & - & $-.472^{*}$ & $.493^{*}$ & .155 & $.607 * *$ & $.508^{*}$ & $.487^{*}$ & .158 \\
\hline 5. Cognition and general knowledge & -.171 & $-.606^{* *}$ & .037 & -.271 & - & -466 & .035 & -.437 & -.419 & $-.612 * *$ & -.067 \\
\hline 6. Curriculum & .156 & $-.483^{*}$ & .163 & -.152 & .315 & - & $.493 *$ & $.724 * *$ & $.819 * *$ & $.718^{* *}$ & $.621 * *$ \\
\hline 7. Family & -.003 & $-.558^{*}$ & .122 & -.064 & .394 & $.486^{*}$ & - & $.550^{*}$ & $.451^{*}$ & $.570^{*}$ & $.686^{* *}$ \\
\hline 8. Teachers & .159 & -.102 & -.239 & -.343 & .283 & $.517^{*}$ & .264 & - & $.736^{* *}$ & $.786^{* *}$ & $.793 * *$ \\
\hline 9. Assessment & .094 & -.354 & .075 & -.111 & .229 & $.736^{* *}$ & .408 & $.598^{*}$ & - & $.749 * *$ & $.793^{* *}$ \\
\hline 10. Leadership & .201 & .102 & -.439 & -.316 & .123 & .475 & .079 & $-.608 * *$ & .475 & - & $-.527 *$ \\
\hline 11. Transition & .161 & .292 & .185 & .296 & $-.585^{*}$ & .118 & -.207 & -.163 & .028 & .025 & - \\
\hline
\end{tabular}

Note. ASA=above state average, $\mathrm{BSA}=$ below state average.

$* p<.05, * * p<.01 ; \rho$ is the symbol for Spearman's rho. 
Table 4.17 also reveals ready child indicator cognition and general knowledge and ready school practice leadership had a negative, significant correlation for BSA principals. BSA principals who ranked ready child indicator cognition and general knowledge important tended to implement leadership ready school practices at low levels, and vice versa, $\rho=-.612, p<.01$.

Also in Table 4.17, there was a negative, significant correlation for ASA principals between ranking ready child indicator cognition and general knowledge and rating transition practices. ASA principals who ranked cognition and general knowledge important tended to implement transition practices at low levels, and vice versa, $\rho=-.585$, $p<.01$. Other results in Table 4.17 indicate ASA principals with higher curriculum and family practices tended to rank ready child indicator health and physical well-being not as important as other ready child indicators and vice versa (Curriculum, $\rho=-.483, p<.01$; Family, $\rho=-.558, p<.01)$.

Although not part of the research question, other findings in Table 4.17 for BSA principals are worthy of discussion in Chapter V. In general, BSA principals implemented ready school practices at high levels. For example, significant correlations existed between curriculum practices and all of the other ready school practices; Family, $\rho=.493, p<.01$; Teacher, $\rho=.724, p<.01$; Assessment, $\rho=.819, p<.01$; Leadership $\rho=.718$, $p<.01$; and Transition, $\rho=.621, p<.01$.

As noted in Table 4.18, BSA principals who ranked curriculum ready school indicator as important also implemented transition practices at high levels, $\rho=.522, p<.01$. No significant correlations were found between ASA principal rankings of ready school indicators and ratings of ready school practices. 
Table 4.19 reveals a negative, significant correlation between health and physical well-being ready child ranking and teacher ready school practices. BSA Kindergarten teachers who ranked physical health and well-being important tended to rate teacher practices low, and vice versa, $\rho=-.454, p<.01$.

Findings in Table 4.20 indicate a significant correlation between leadership ready school ranking and family ready school practices. BSA Kindergarten teachers who ranked leadership important, rated implementation of family practices at high levels, $\rho=.562, p<.01$.

In Table 4.21, a negative, significant finding was made for BSA preschool teachers. Those who ranked language and communication ready child indicator important, implemented assessment ready school practices at low levels, and vice versa, $\rho=-.511, p<.01$. There were no significant correlations found for ASA preschool teachers. Similar to BSA principal responses, significant correlations were found among ready school practices for BSA preschool teachers. In general, BSA preschool teachers tended to implement ready school practices at high levels.

In Table 4.22, several significant findings were made for BSA and ASA preschool teachers. A negative, significant correlation was found for the ready school assessment indicator and ready school family practices. BSA preschool teachers who ranked ready school indicator assessment as important tended to implement family practices at low levels, and vice versa, $\rho=-.425, p<.01$.

Table 4.22 also reveals a positive, significant correlation between ready school indicator ranking of transition and teacher ready school practices. BSA preschool 
teachers who ranked transition ready child indicator important implemented teacher practices at high levels, $\rho=.463, p<.01$.

Negative, significant correlations for ASA preschool teachers were found as noted in Table 4.22. ASA preschool teachers who implemented ready school assessment practices at high levels tended to rank ready school assessment indicator as less important, $\rho=-.559, p<.01$. A negative, significant correlation was also found between assessment ready school ranking and transition ready school practices for ASA preschool teachers, $\rho=-.444, p<.01$.

\section{Combined Role Groups}

Table 4.23 and 4.24 provide the results for all educators regarding ready child and ready school rankings and ready school practices. Overall, significant correlations were not found between how educators ranked ready child and ready school indicators and how they rated the level of implementation of ready school practices. 


\section{Table 4.18}

Correlations Between Above State Average and Below State Average Principal Responses on Ready School Indicator Rankings (1-6) and Ready School Practices (7-12)

\begin{tabular}{|c|c|c|c|c|c|c|c|c|c|c|c|c|}
\hline \multirow{2}{*}{$\begin{array}{l}\text { Ready school indicator rankings } \\
\text { and ready school practices }\end{array}$} & \multicolumn{6}{|c|}{ ASA } & \multicolumn{6}{|c|}{ BSA } \\
\hline & 1 & 2 & 3 & 4 & 5 & 6 & 7 & 8 & 9 & 10 & 11 & 12 \\
\hline 1. Curriculum & - & -345 & -.160 & -.168 & -.253 & -.170 & -.265 & .127 & .251 & .449 & .277 & $.522 *$ \\
\hline 2. Family & $-.259 * *$ & - & -.440 & -.373 & -.346 & .407 & -.181 & .295 & .074 & -.220 & -.037 & .072 \\
\hline 3. Teachers & $-.750 * *$ & -.297 & - & .396 & -.207 & .022 & -.054 & -.158 & .079 & -.027 & -.066 & -.145 \\
\hline 4. Assessment & -.428 & -.406 & .114 & - & -.064 & -.166 & -.335 & -.237 & -.280 & -.125 & -.313 & -.098 \\
\hline 5. Leadership & -.359 & $-.645^{* *}$ & .276 & .034 & - & $-.626 * *$ & -.073 & -.349 & -.194 & -.239 & -.187 & -.392 \\
\hline 6. Transition & -.410 & -.278 & .418 & -.144 & -.001 & - & .236 & .453 & .239 & .097 & .287 & .126 \\
\hline 7. Curriculum & .186 & .250 & -.407 & .063 & -.003 & -.463 & - & $.493^{*}$ & $.724 * *$ & $.819 * *$ & $.718 * *$ & $.621 * *$ \\
\hline 8. Family & .179 & .154 & -.363 & .213 & -.157 & -.306 & $.486^{*}$ & - & $.550 *$ & .451 & $.570^{*}$ & $.686^{* *}$ \\
\hline 9. Teachers & -.325 & -.144 & .184 & .206 & .263 & -.057 & $.517^{*}$ & .264 & - & $.736 * *$ & $.786^{* *}$ & $.634 * *$ \\
\hline 10. Assessment & -.316 & -.037 & .107 & .203 & .233 & -.095 & $.736 * *$ & .408 & $.598^{*}$ & - & $.749 * *$ & $.793 * *$ \\
\hline 11. Leadership & -.177 & -.054 & -.069 & -.061 & .338 & -.095 & .475 & .079 & $.608 * *$ & .475 & - & $.527 *$ \\
\hline 12. Transitions & .157 & .327 & -.001 & -.468 & -.036 & -.176 & .118 & -.207 & -.163 & .028 & .025 & - \\
\hline
\end{tabular}

Note. ASA=above state average, BSA=below state average.

$* p<.05, * * p<.01 ; \rho$ is the symbol for Spearman's rho. 


\section{Table 4.19}

Correlations Between Above State Average and Below State Average Kindergarten Responses on Ready Child Indicator Rankings (1-5) and Ready School Practices (6-11)

\begin{tabular}{|c|c|c|c|c|c|c|c|c|c|c|c|}
\hline \multirow{2}{*}{$\begin{array}{l}\text { Ready child indicator rankings and } \\
\text { ready school practices }\end{array}$} & \multicolumn{6}{|c|}{ ASA } & \multicolumn{5}{|c|}{ BSA } \\
\hline & 1 & 2 & 3 & 4 & 5 & 6 & 7 & 8 & 9 & 10 & 11 \\
\hline 1. Approach to learning & - & -.255 & -.383 & $-.356^{*}$ & -.081 & .039 & -.359 & .162 & $-.393 *$ & -.122 & -.326 \\
\hline 2. Health and physical well being & -.081 & - & -.236 & .141 & $-.622^{* *}$ & -.048 & -.123 & $-.454 *$ & -.205 & -.327 & .022 \\
\hline 3. Language and communication & $-.363^{*}$ & $-.337^{*}$ & - & -.123 & .022 & .044 & .260 & .034 & .351 & .143 &, 158 \\
\hline $\begin{array}{l}\text { 4. Social and emotional } \\
\text { development }\end{array}$ & $-.620^{* *}$ & .093 & -.040 & - & $-.493^{* *}$ & -.175 & -.096 & -.221 & -.039 & -.103 & .002 \\
\hline $\begin{array}{l}\text { 5. Cognition and general } \\
\text { knowledge }\end{array}$ & -.136 & $-.736^{* *}$ & .014 & -.214 & - & .074 & .284 & .338 & .267 & .309 & .088 \\
\hline 6. Curriculum & .291 & .170 & -.035 & -.215 & -.283 & - & .147 & $.382 *$ & $.620 * *$ & $.450^{*}$ & .110 \\
\hline 7. Family & .233 & .164 & -.043 & -.176 & -.240 & $.647^{*}$ & - & .188 & .292 & $.371^{*}$ & $.538^{* *}$ \\
\hline 8. Teachers & .187 & .257 & -.014 & -.202 & -.254 & $.548 * *$ & $.444 * *$ & - & $.426^{*}$ & $.508^{* *}$ & .273 \\
\hline 9. Assessment & $.351 *$ & .233 & -.065 & -.227 & -.367 & $.694 * *$ & $.744 * *$ & $.525^{* *}$ & - & .256 & .116 \\
\hline 10. Leadership & $.308^{*}$ & .159 & -.063 & -.127 & $-.316^{*}$ & $.662 * *$ & $.430 * *$ & $.429 * *$ & $.694 * *$ & - & $.384 *$ \\
\hline 11. Transition & .181 & .103 & -.014 & -.164 & -.142 & $.534 * *$ & $.584 * *$ & $.368^{*}$ & $.711^{* *}$ & $.728 * *$ & - \\
\hline
\end{tabular}

Note. ASA=above state average, BSA=below state average.

$*_{p}<.05, * * p<.01 ; \rho$ is the symbol for Spearman's rho. 


\section{Table 4.20}

Correlations Between Above State Average and Below State Average Kindergarten Responses on Ready School Indicator Rankings (1-6) and Ready School Practices (7-12)

\begin{tabular}{|c|c|c|c|c|c|c|c|c|c|c|c|c|}
\hline \multirow{2}{*}{$\begin{array}{l}\text { Ready school indicator rankings } \\
\text { and ready school practices }\end{array}$} & \multicolumn{6}{|c|}{ ASA } & \multicolumn{6}{|c|}{ BSA } \\
\hline & 1 & 2 & 3 & 4 & 5 & 6 & 7 & 8 & 9 & 10 & 11 & 12 \\
\hline 1. Curriculum & - & -.303 & -.198 & .239 & -.084 & -.308 & -.072 & -.162 & .302 & -.226 & .104 & -.050 \\
\hline 2. Family & $-.522 * *$ & - & $-.371 *$ & -.293 & $-.454^{*}$ & -.192 & -.066 & -.182 & -.063 & -.020 & .016 & .009 \\
\hline 3. Teachers & -.074 & -.209 & - & -.187 & -.157 & .172 & .125 & -.162 & .024 & .206 & -.123 & -.180 \\
\hline 4. Assessment & .124 & -.241 & -.110 & - & .051 & -.312 & -.057 & .076 & .097 & -.140 & .149 & .177 \\
\hline 5. Leadership & -.142 & -.132 & -.129 & $-.456^{* *}$ & - & -.140 & .055 & $.562 * *$ & -.048 & .126 & .126 & .186 \\
\hline 6. Transition & -.115 & -.229 & -.081 & -.087 & -.162 & - & -.044 & -.142 & -.311 & -.038 & -.218 & -.036 \\
\hline 7. Curriculum & .002 & .054 & .214 & -.211 & -.213 & .067 & - & .147 & .382 & $.620^{* *}$ & $.450 *$ & .110 \\
\hline 8. Family & -.140 & .188 & .010 & -.172 & -.151 & .185 & $.647 * *$ & - & .188 & .292 & $.371 *$ & $.538 * *$ \\
\hline 9. Teachers & -.192 & .208 & .092 & -.102 & -.199 & .032 & $.548^{* *}$ & $.444 *$ & - & .426 & $.508^{* *}$ & .273 \\
\hline 10. Assessment & -.006 & .287 & -.056 & -.094 & -.299 & .003 & $.694 * *$ & $.744 * *$ & $.525^{* *}$ & - & .256 & .116 \\
\hline 11. Leadership & .073 & .130 & -.022 & -.212 & -.105 & .129 & $.662 * *$ & $.430 * *$ & $.429 * *$ & $.694 * *$ & - & .384 \\
\hline 12. Transitions & -.086 & $.324 *$ & -.042 & -.285 & -.076 & .060 & $.534 * *$ & $.584 * *$ & $.368^{*}$ & $.711^{* *}$ & $.728 * *$ & - \\
\hline
\end{tabular}

Note. ASA=above state average, BSA=below state average.

$* p<.05, * * p<.01 ; \rho$ is the symbol for Spearman's rho. 


\section{Table 4.21}

Correlations Between Above State Average and Below State Average Preschool Responses on Ready Child Indicator Rankings (1-5) and Ready School Practices $(7-12)$

\begin{tabular}{|c|c|c|c|c|c|c|c|c|c|c|c|}
\hline \multirow[b]{2}{*}{$\begin{array}{l}\text { Ready child indicator rankings and } \\
\text { eady school practices }\end{array}$} & \multicolumn{6}{|c|}{ ASA } & \multicolumn{5}{|c|}{ BSA } \\
\hline & 1 & 2 & 3 & 4 & 5 & 6 & 7 & 8 & 9 & 10 & 11 \\
\hline 1. Approach to learning & - & .315 & $-.506^{* *}$ & $-.513 * *$ & -.362 & .207 & -.045 & .251 & .279 & -.011 & -.019 \\
\hline 2. Health and physical well being & -.260 & - & -.341 & -.322 & $-.706 * *$ & .002 & -.053 & .078 & .014 & .041 & .011 \\
\hline 3. Language and communication & -.302 & -.198 & - & -.049 & .148 & -.187 & -.211 & -.379 & $-.511 * *$ & -.292 & -.096 \\
\hline $\begin{array}{l}\text { 4. Social and emotional } \\
\text { development }\end{array}$ & -.306 & -.185 & -.213 & - & -.091 & -.135 & .088 & -.222 & -.067 & .125 & -.023 \\
\hline $\begin{array}{l}\text { 5. Cognition and general } \\
\text { knowledge }\end{array}$ & -.099 & $-.542^{* *}$ & -.110 & -.227 & - & .071 & .194 & .177 & .187 & .103 & .102 \\
\hline 6. Curriculum & -.008 & -.062 & .135 & -.169 & .140 & - & .243 & .391 & $.408 *$ & $.572 * *$ & .244 \\
\hline 7. Family & .018 & -.036 & .217 & -.241 & .032 & $.697 * *$ & - & $.687 * *$ & $.600 * *$ & $.598 * *$ & $.623^{* *}$ \\
\hline 8. Teachers & .069 & .002 & -.020 & -.126 & .144 & $.757 * *$ & $.572 * *$ & - & $.603 * *$ & $.585^{* *}$ & $.577 * *$ \\
\hline 9. Assessment & -.123 & .040 & .256 & -.080 & -.027 & $.524 * *$ & $.561 * *$ & $.561 * *$ & - & $.654 * *$ & $.468 *$ \\
\hline 10. Leadership & -.098 & -.097 & .110 & .154 & -.002 & $.687 * *$ & $.476^{*}$ & $.714 * *$ & $.593 * *$ & - & $.696^{* * *}$ \\
\hline 11. Transition & -.077 & .073 & .107 & .021 & -.076 & .314 & $.468^{*}$ & $.429 *$ & $.783 * *$ & $.535^{* *}$ & - \\
\hline
\end{tabular}

Note. ASA=above state average, BSA=below state average.

$*_{p}<.05, * * p<.01 ; \rho$ is the symbol for Spearman's rho. 


\section{Table 4.22}

Correlations Between Above State Average and Below State Average Preschool Responses on Ready School Indicator Rankings (1-6) and Ready School Practices (6-12)

\begin{tabular}{|c|c|c|c|c|c|c|c|c|c|c|c|c|}
\hline \multirow{2}{*}{$\begin{array}{l}\text { Ready school indicator rankings } \\
\text { and ready school practices }\end{array}$} & \multicolumn{6}{|c|}{ ASA } & \multicolumn{6}{|c|}{ BSA } \\
\hline & 1 & 2 & 3 & 4 & 5 & 6 & 7 & 8 & 9 & 10 & 11 & 12 \\
\hline 1. Curriculum & - & -.266 & -.130 & .075 & -.354 & -.239 & .125 & .070 & -.041 & -.022 & .107 & .061 \\
\hline 2. Family & -.084 & - & -154 & $-603 * *$ & -360 & .319 & -.126 & .100 & .085 & -.248 & -.167 & -.043 \\
\hline 3. Teachers & $-.404 *$ & -.258 & - & .096 & -.248 & -.167 & .036 & .252 & .287 & .328 & .380 & .233 \\
\hline 4. Assessment & -.077 & -.305 & .227 & - & .232 & $-.610 * *$ & -.180 & $-.425 *$ & -.379 & -.085 & -.356 & -.375 \\
\hline 5. Leadership & -.326 & -.319 & -.228 & $-.417 *$ & - & $-.389 *$ & -.208 & -.125 & -.396 & -.100 & -.260 & -.202 \\
\hline 6. Transition & -.298 & .285 & .040 & -.194 & -.235 & - & .323 & .248 & $.463^{*}$ & .233 & .331 & .187 \\
\hline 7. Curriculum & -.209 & -.071 & .068 & -.224 & .154 & -.062 & - & .243 & .391 & .408 & $.572 * *$ & .244 \\
\hline 8. Family & .011 & .175 & -.149 & -.340 & .061 & -.088 & $.697 * *$ & - & $.687 * *$ & $.600 * *$ & $.598 * *$ & $.623^{* *}$ \\
\hline 9. Teachers & -.264 & .068 & -.164 & -.378 & $-.391 *$ & .062 & $.757 * *$ & $.572 *$ & - & $.603 * *$ & $.598 * *$ & $.577 * *$ \\
\hline 10. Assessment & -.245 & .268 & .157 & $-.559 * *$ & .179 & .110 & $.524 * *$ & $.561 * *$ & $.561 * *$ & - & $.654 * *$ & $.468 *$ \\
\hline 11. Leadership & $-.389 *$ & .186 & .129 & -.259 & .137 & .352 & $.687 * *$ & $.476^{*}$ & $.714 * *$ & $.593 * *$ & - & $.696^{* *}$ \\
\hline 12. Transitions & -.246 & .366 & .192 & $-.444 *$ & .044 & .150 & .314 & $.468 *$ & $.429 *$ & $.783 * *$ & $.535^{* *}$ & - \\
\hline
\end{tabular}

Note. $\mathrm{ASA}=$ above state average, $\mathrm{BSA}=$ below state average.

${ }^{*} p<.05, * * p<.01 ; \rho$ is the symbol for Spearman's rho. 


\section{Table 4.23}

Overall Correlations Between Educator Rankings of Ready Child Indicators and Ratings of School Practices

\begin{tabular}{|c|c|c|c|c|c|c|c|c|c|c|c|}
\hline $\begin{array}{l}\text { Ready child indicator rankings a } \\
\text { ready school practices }\end{array}$ & 1 & 2 & 3 & 4 & 5 & 6 & 7 & 8 & 9 & 10 & 11 \\
\hline 1. Approach to learning & 一 & & & & & & & & & & \\
\hline 2. Health and physical well being & -.115 & - & & & & & & & & & \\
\hline 3. Language and communication & $-.376 * *$ & $-.267 * *$ & - & & & & & & & & \\
\hline $\begin{array}{l}\text { 4. Social and emotional } \\
\text { development }\end{array}$ & $-.518 * *$ & -.031 & -.053 & - & & & & & & & \\
\hline $\begin{array}{l}\text { 5. Cognition and general } \\
\text { knowledge }\end{array}$ & -.106 & $-.638 * *$ & -.055 & -.280 & - & & & & & & \\
\hline 6. Curriculum & .120 & -.013 & -.002 & -.116 & .003 & - & & & & & \\
\hline 7. Family & .048 & -.007 & -.033 & -.099 & .076 & $.497 * *$ & - & & & & \\
\hline 8. Teachers & $.188 *$ & -.016 & -.150 & -.122 & .082 & $.540 * *$ & $.455^{* *}$ & - & & & \\
\hline 9. Assessment & .100 & .017 & -.023 & -.098 & -.004 & $.653 * *$ & $.582 * *$ & $.552 * *$ & - & & \\
\hline 10. Leadership & .118 & .007 & -.069 & -.008 & -.062 & $.610 * *$ & $.458 * *$ & $.542 * *$ & $.611 * *$ & 一 & \\
\hline 11. Transition & -.006 & .053 & -.004 & -.019 & -.031 & $.379 * *$ & $.540 * *$ & $.379 * *$ & $.574 * *$ & $.593 * *$ & - \\
\hline
\end{tabular}

Note. ASA=above state average, $\mathrm{BSA}=$ below state average.

${ }^{*} p<.05, * * p<.01 ; \rho$ is the symbol for Spearman's rho. 


\section{Table 4.24}

Overall Correlations Between Educator Rankings of Ready School Indicators and Ratings of Ready School Practices

\section{Ready school indicator rankings}

and ready school practices

1

2

3

4

5

6

$$
\begin{array}{lc}
-.239^{* *} & - \\
-.274^{* *} & -.241^{* *}-
\end{array}
$$

3. Teachers

$$
-.002-.366^{* *} \quad .055
$$

5. Leadership

$$
-.294^{* *}-.333^{* *}-.132 \quad-.160^{*} \quad-
$$

6 6. Transition

7. Curriculum

8. Family

9. Teachers

10. Assessment

$-.237^{* *}-.023 \quad .031 \quad-.224^{* *}-.208^{* *} \quad-$

$\begin{array}{llllll}-.036 & .008 & .109 & -.155 & -.042 & .044\end{array}$

$\begin{array}{lllllllll}-.086 & .108 & .000 & -.148 & .004 & .078 & .497^{* *} & -\end{array}$

11. Leadership

$\begin{array}{lllllllll}-.107 & .052 & .134 & -.131 & -.027 & .053 & .540^{* *} & .455^{* *} & -\end{array}$

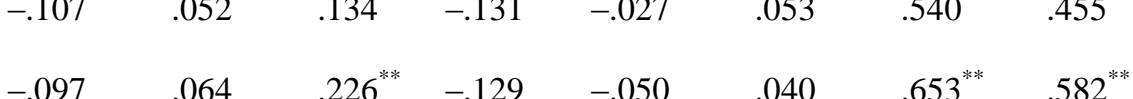

$\begin{array}{lllllllll}.097 & .064 & .226^{* *} & -.129 & -.050 & .040 & .653^{* *} & .582^{* *} & .552^{* *}\end{array}$

12. Transitions

$\begin{array}{lllll}.009 & .032 & .098 & -.170^{*}-.045\end{array}$

$.143 \quad .610^{* *} \quad .458^{* *} \quad .542^{* *} \quad .611^{* *}$

Note. $\mathrm{ASA}=$ above state average, $\mathrm{BSA}=$ below state average.

$* p<.05, * * p<.01 ; \rho$ is the symbol for Spearman's rho. 


\section{Summary}

The goal of this study was to determine whether differences existed in BSA and ASA educator rankings of ready child and ready school indicators and ratings of ready school practices. In addition, correlational analyses were conducted to determine whether relationships existed between how educators ranked ready child and ready school indicators and how they rated the implementation of ready school practices.

The data analyses revealed interesting findings. In Research Question 1, differences were found between BSA and ASA: (a) principals in how they ranked health and physical well-being, (b) preschool teachers in how they ranked approaches to learning, and (c) overall role groups in how they ranked approaches to learning. In Research Question 2, a significant difference was found between BSA and ASA Kindergarten teachers and how they ranked the transition ready school indicator. BSA and ASA Kindergarten teachers differed in how they rated the implementation of teacher ready school practices in Research Question 3a. In addition, in Research Question 3b several negative and positive significant correlations were found between educator rankings of ready child and ready school indicators and how they rated the implementation of ready school practices.

Chapter V is the final chapter of this study. It includes interpretations and discussion of major findings, limitations, implications for policy and practice, recommendations for future research, and concluding thoughts. 


\title{
CHAPTER V \\ DISCUSSION AND CONCLUSIONS
}

\author{
Introduction
}

The first section in Chapter $\mathrm{V}$ is an overview of the study including the problem, purpose, and research questions. The second section provides an interpretation and synthesis of the results and findings. In the third section, implications for policy and practice are discussed. The fourth and final sections provide recommendations for future research on the ready child and the ready school, including the researcher's concluding thoughts.

Overview

A disconnect exists between child readiness expectations (ready child) and public school requirements and expectations (ready school) to meet the goal that all children will enter Kindergarten ready to learn. The conversation of school readiness typically means child readiness for school; however, within the context of this study, it also means that schools need to be ready and prepared for every child.

The purpose of this study was to explore whether differences existed between educators from successful schools (ASA scores) and educators from less successful schools (BSA scores) concerning their perceptions of ready child and ready school success indicators and frequency of implementation of ready school practices. It was anticipated that educators from ASA schools would identify as extremely important ready child and ready school success indicators and certain ready school practices as 
implemented at high levels, and that they that would differ from educator responses from BSA schools. It was also expected that results from this study would provide information such that recommendations could be made to establish ready schools at the preschool through Grade 3 level.

\section{Summary of Major Findings}

Some interesting findings were revealed concerning: (a) differences between BSA and ASA educator rankings of ready child indicators health and physical well-being and approaches to learning (Research Question 1), (b) differences between BSA and ASA rankings of transition ready school indicator (Research Question 2), and (c) correlations between ratings of ready school practices and rankings of ready child and ready school indicators (Research Question 3). In Chapter II, the researcher discussed in relation to the conceptual framework whether mediating factors such as standards, expectations, and the school's mission or vision as well as the school's performance level might influence educator perceptions of the ready child and the ready school.

$$
\text { Interpretation of Results and Findings }
$$

\section{Demographic Findings}

In general, similarities were found between BSA and ASA sample role groups. The number $(n)$ of principals (BSA/21; ASA/22) and preschool teachers (both BSA and ASA had 30) who participated in the survey were almost equal. The number of BSA Kindergarten teacher participants (35) was lower than ASA Kindergarten teachers (47).

Little difference was found between years of service at their schools between BSA and ASA educators. The majority of educators had been at their particular school for 7 years or less. 
It was no surprise that all of the BSA schools had FRL rates greater than the state average; however, $49 \%$ of the ASA sample schools also had FRL rates greater than the state average. The literature and research in Chapter II discuss correlations between lowSES students and schools with low achievement and low performance. According to studies by Duncan et al. (2011) and Hart and Risley (1995), SES is one of the greatest determinants of school success, more than race or ethnicity. Analyses by Isaacs and Magnuson (2011) and Lee and Burkham (2002) of differences in social backgrounds relative to achievement at school entry found differences in test scores based on race and ethnicity, but the differences associated with SES were even more substantial. However, the literature and research in Chapter II also identifies features of HP/HP schools that are successful in educating students from low-SES families.

Evidence from schools across the nation has shown that they have achieved at high levels and closed gaps in spite of demographic challenges. The ASA schools in this study with high poverty levels serve as examples. The Coleman Report (Coleman, 1966), that was discussed in Chapter II, triggered studies about effective and HP/HP schools because many schools failed to provide equal educational opportunities to students, especially students from low-SES homes. Accordingly, HP/HP schools have strong leadership, high levels of family involvement, on-going assessment of student work, comprehensive curriculum, and effective teachers (Christie, 2004; Kannapel \& Clements, 2005). These characteristics symbolize ready school indicators used in this study. Results and Findings from Research Question 1: Ready Child Rankings

Differences were found between BSA and ASA educator rankings of ready child indicators. ASA principals ranked health and physical well-being more important than BSA principals did. The NEGP (1990) Goal One Workgroup, identified health and 
physical well-being as one of three objectives to achieve the ready child goal that all children would enter school ready to learn (Lewitt \& Baker, 1995).

Although the data do not speak to this, ASA principals could be more concerned with the health of young children entering their schools for the first time because almost half of the ASA schools have high numbers of FRL students. Poor children tend to be less healthy than are children of higher-SES families (Evans, 2004). The research suggested nutrition, physical health, and gross and fine motor skills have an effect on child learning and predict later school success (Copple and Bredecamp, 2009; West et al., 2001).

By contrast, although the higher numbers of FRL students in BSA schools might at first suggest that this argument implies that educators would have even more concerns about the health of young children because all of the BSA schools had high numbers of FR/L students, these schools might have policies and resources already in place to address health issues. If so, that would explain why BSA principals reported less concern about health for their children; therefore, they might have reported it as a low concern, not because it isn't important, but because they are already managing this important issue that is likely more prevalent in BSA schools. BSA principals could be more concerned with other ready child indicators that could affect student performance on the state assessment.

BSA and ASA preschool teachers ranked ready child indicator approaches to learning differently. BSA preschool teachers ranked this indicator more important than ASA preschool teachers. The literature and research suggest approaches to learninghow young children are motivated to learn, problem solve, and persist in tasks - has become important to early childhood conversations and is one of the most important 
ready child indicators for 21st century learning (Copple \& Bredecamp, 2009; Daily et al., 2010, Yen et al., 2004).

As discussed in Chapter II, approaches to learning is not explicitly identified as one of Kentucky's early childhood standards, although it is included in the state's definition of school readiness (ready child) and is one of the Head Start child outcomes. Head Start teachers were included in this study, identified as preschool teachers. It is possible that preschool teachers in BSA schools receive professional development in this area and realize the importance of approaches to learning in preparing children for Kindergarten and higher levels of learning. In addition, children from low SES homes are in the population in BSA schools; therefore, they do not have the learning experiences that children from higher-SES families have because of lack of financial resources and parental characteristics (Hart \& Risley, 1995; Isaacs, 2012). Therefore, it is understandable that BSA preschool teachers would rank approaches to learning important. BSA educators in general felt that a child's motivation to learn (approaches to learning) was important.

Results and Findings from Research Question 2: Ready School Rankings

One significant finding from this question was that BSA and ASA Kindergarten teachers perceived transition differently. The transition plan, as described in the Ready Child, Ready School Survey (Appendix A) and supported by literature and research, is a comprehensive written plan (live document) and includes on-going communication and a formal process between the school and early care education programs (Bohan-Baker \& Little, 2002; Early et al., 2001; Halle et al., 2008). The process of transitioning young children from one program or setting (preschool program or home) to another (Kindergarten) would look different for different populations. 
BSA Kindergarten teachers perceived transition as an important indicator for the ready school. One of the key components of being a ready school for those with high percentages of low-SES children might be a focus on transition, which might not be as necessary in higher-SES schools. According to the NEGP (1990) Ready Schools Resource Group (Shore, 1998), a ready school smoothes the transition between home and school and strives for continuity between early childhood programs and schools. If a comprehensive transition plan does not exist and communication with children's previous early childhood programs is lacking or children have not had early learning experiences, concerns about incoming children would be appropriate (Rouse, Brooks-Gunn, \& McLanahan, 2005). It is understandable that BSA Kindergarten teachers would recognize transition as important.

A great majority of ASA Kindergarten teachers (79\%) ranked transition as a least important indicator for the ready school. Perhaps their schools have successful transition programs; therefore, they rank other ready school indicators as more important to improving or maintaining their school test scores. Early et al. (2001) suggested that ready schools have three characteristics: they (a) reach out to connect families and communities to schools, (b) make connections before the first day of school, and (c) reach out with appropriate intensity. Alternatively, ASA Kindergarten teacher responses could also suggest that overall their incoming population of children has had adequate socialization experiences to a school environment, which would ease their transition process. Whatever the reason, this finding highlights the critical feature that BSA schools must carefully and thoughtfully design supports to facilitate transition to Kindergarten, a challenge that may be less critical in ASA schools. 
Results and Findings: Ready Child, Ready School Open-Ended Questions

The open-ended questions inquired about (a) one thing educators desired for every child entering Kindergarten, and (b) one thing they would change about their school for greater success. The findings indicated ASA educators agreed about both questions. BSA principals and preschool teachers agreed on both questions, but BSA Kindergarten teachers had different responses.

ASA educators believed that every ready child should have a stable home environment. Evans (2004), researching childhood poverty, suggested that poor children are "exposed to more family turmoil, violence, chaos, and instability" (p. 77) than children from economically advantaged homes. Educators who are accustomed to high performance should be concerned about any barrier that would prevent a student from achieving at high levels.

ASA educators' response to one thing they would change about their school was resources. Resources in this context meant such things as more time, money, technology, smaller class size, and interventions for struggling students. According to their agreement, about one thing that a ready child needs, could it be that ASA educators have a shared understanding such that they know the resources needed for successful transition and subsequent successful school experiences for young children? Perhaps ASA educators work in schools where staff agree on and embrace the vision and mission and have opportunities to discuss goals and objectives for student success, as well as barriers that might prevent it from happening. Brock and Groth (1983) found that schools where the administrator, faculty, and staff perceived or expected real opportunities to improve academic achievement are able to transform their school for greater student impact than schools whose staff and administrators perceived very little hope for increasing student 
learning. Essentially, when staff have high expectations, the outcome is higher student learning.

BSA principals and preschool teachers agreed on both of the open-ended questions. They agreed that they wanted a stable home for the ready child and that they wanted greater parental involvement for a successful school (ready school). Their answers centered on the family. The literature and research discussed in Chapter II make the case for correlations between low-SES and parental involvement and low parent involvement and student achievement. BSA principals would probably recognize and understand the importance of partnerships with families to promote child learning and to be potentially part of the school improvement plan. The Head Start Program and the Kentucky Preschool Program both serve low-SES children and have regulations that require active parent involvement programs; therefore, preschool teachers would share, along with school leadership, the responsibility to ensure that parents would be engaged in meaningful activities.

BSA Kindergarten teachers were the outliers with their peers. Their responses to "one thing for every child" were stronger parent involvement and the child motivated to learn, and "one thing to change at their school" was more resources. Although lower performing schools in Kentucky receive additional resources (e.g., technical assistance and professional development to improve test scores [KDE, 2014]), given the challenges of educating their population of students, these resources might not be adequate for BSA schools.

Results and Findings from Research Question 3

Research Question 3 had two parts. In Research Question 3a, differences between BSA and ASA educator ratings of ready school practices in their schools were examined. 
ASA educators rated ready school indicator teacher practices higher than BSA educators did. A greater percentage of ASA educators said teacher practices were implemented $100 \%$ of the time. The teacher practices were averaged among subcategories such as providing a safe and healthy environment, valuing diversity, and consideration of learning needs of each individual child for instructional planning. The teacher is considered the single most determining factor of quality and account for greater differences in academic achievement (Burke \& Burke, 2005; Hamre \& Pianta, 2001; Kagan, 2009; Kannapel \& Clements, 2005; Leithwood et al., 2008).

Other research discussed in Chapter II suggested that effective teachers create a climate of high expectations, take responsibility for the success of every child, and are good decision makers-adjusting the curriculum and instruction to meet individual learning needs (Ackerman \& Barnett, 2005; Copple \& Bredekamp, 2009; Daniels, 2011; Maxwell \& Clifford, 2004). Considering these characteristics, one would assume high quality instruction is valued in ASA schools and that school leaders intentionally recruit highly effective teachers with proven records of accomplishment for student achievement; however, this area warrants further investigation.

Research Question 3b concerned correlations between ready school practices and rankings of ready child and ready school indicators for BSA and ASA educators. The findings revealed several significant correlations both positive and negative. The positive relationships are mentioned here.

Correlations Between Ready Child Rankings and Ready School Practices

BSA principals who ranked ready child indicator Social Emotional Development important tended to implement Curriculum, Teacher, Assessment, and Leadership ready school practices at high levels. The relationships could be conceivable if the practices 
were actually implemented at high levels then the child's social and emotional needs would be met; however, there is some skepticism about BSA principal responses to this question which is discussed later in this section.

Correlations Between Ready School Rankings and Ready School Practices

The findings revealed that BSA principals who ranked ready school curriculum important also implemented transition practices at high levels. A curriculum that meets the description (in the survey) as being developmentally appropriate, meaningful to children, and culturally responsive and highly implemented would ease the transition for young children; however, the reliability of BSA principal responses is questionable.

In addition, in Research Question 3b, BSA Kindergarten teachers who rated family ready school practices highly implemented, also ranked ready school indicator leadership important. School leaders set the tone for active family engagement. HP/HP schools have leaders who focus their efforts to involve parents as partners in helping students to meet high standards and engage families in strategies that are respectful of cultures and perspectives (Dearing et al., 2008; Leithwood et al., 2008).

A finding for BSA preschool teachers in Research Question $3 \mathrm{~b}$ revealed a significant correlation between ready school indicator transition and teacher ready school practices. BSA preschool teachers who ranked transition as important also implemented family practices at high levels. Head Start Program Standards require transition plans; therefore, BSA preschool teacher responses could suggest that they play a role in the transition process and actively involve families. BSA preschool teacher responses could also indicate concern for children who leave them to attend Kindergarten and their desire for children to have positive transition experiences. One of the key components of being 
a ready school for those with high percentages of low-SES children might be a focus on transition, which may not be as necessary in higher-SES schools.

It is difficult to determine whether the relationships described in Research Question $3 \mathrm{~b}$ are valid because of the findings in Chapter IV. In general, BSA educators perceived themselves as implementing ready school practices at high levels. If that were the case, should not student test scores demonstrate it? It was hypothesized that ASA educators might implement ready school practices at high levels. Teachers with high efficacy tend to persist with struggling students, and teacher efficacy is related to student scores (Fantuzzo et al., 2012). Although one's perceptions could have relevance to one's action (Bandura, 1986), BSA responses in this area are questionable and could be cause for further investigation.

Limitations

There are some concerns about educator responses, especially as they pertained to implementing ready school practices. According to their answers, BSA educators implemented ready school practices at high levels. This study was a nonexperimental study and used a survey to capture educator perceptions. In addition, although one's selfperceptions are related to one's actions, it is doubtful whether BSA educator perceptions reflected actual implementation levels of ready school practices. Therefore, conclusive statements cannot be made about differences between BSA and ASA ready school practices that might contribute to student and school success.

Implications for Policy and Practice

This study accomplished several objectives. First, it contributes to the literature and research on school readiness by connecting the ready child and the ready school. Second, it raises awareness about the ready school, which could shift the trajectory for 
persistently low-performing schools and potentially lead to the development of preschool through Grade 3 schools. Third, it provides further support for existing research on HP/HP schools.

The NEGP (1990) established the platform for the ready child and ready school in the early 1990s. It should reconvene and create a national plan to prepare every child for school and every school for every child so that all educators would have a common understanding of the ready child and the ready school. The creation of such a plan should not only involve district and school leaders who represent all student populations, but also Kindergarten and preschool teachers.

In Kentucky, the KDE should consider adding approaches to learning as a separate early childhood standard because it is included in their definition of the ready child and was ranked important by BSA educators. In addition, state, district leaders, and elected officials should review this study and begin to include the ready school in their ready child conversations (school readiness). KDE should also consider piloting the High/Scope (2006b) Ready School Assessment in several ASA and BSA schools. Ultimately, they should establish Ready Schools at the preschool through Grade 3 level and begin this work with BSA schools. The transformation would not require additional resources and the benefits to children and schools will have a lasting impact, contributing to meeting the KDE goal that students will graduate from high school, college and career ready.

Locally, school leaders might want to conduct an informal survey of their staff using the Ready Child, Ready School Survey to determine whether they have a shared understanding of the ready child and the ready school for successful school improvement 
planning. At the very least, differences in perceptions should be examined because they might have implications for school practices and priorities.

Future Research

The findings indicate an extension of this study (on-sight validation) would be useful, especially if sample participants are included. In this extended study, investigation of some of the negative, significant findings might be warranted. The researcher also suggests a focus on ready child indicator approaches to learning and ready school teacher practices in the extended study. The literature and research support them as important factors for higher levels of achievement.

Several BSA and ASA schools had participants representing all three of the role groups-principals, Kindergarten teachers, and preschool teachers. This might be an opportunity to select these schools for a causal — comparative study and extend it to a longitudinal study to compare BSA and ASA student test scores over time.

Another recommendation for future research is to select intentionally three schools, from this study, for in-depth case study analyses. The three schools should be (a) one BSA school with a high FRL rate and low test scores representing high poverty and low performance, (b) an ASA school with a high FRL rate and high test scores representing $\mathrm{HP} / \mathrm{HP}$, and (c) an ASA school with a low FRL rate and high test scores representing low poverty and high performance.

\section{Concluding Thoughts}

The researcher contends that this study is important to young children as they transition to Kindergarten and to the schools that receive them. At the very least, it should spark the attention of school leaders, especially those struggling with low performance, such that they would want to learn more about the relationship between the ready child 
and the ready school. School leaders could then assess their current practices to determine whether they are doing all they can do to support student learning and to affirm families as partners in their child's education.

School leaders may want to consider sectioning an area in the school and designating it as a ready school by locating preschool through Grade 3 classrooms in that area. Although a ready school would look different for different populations, it should include at a minimum content alignment, collaborative teaching and learning across grades, intentional parent and family programs, and teachers with appropriate certification and content knowledge. This transformation would require a visionary leader who is committed to the success of every child, teacher, and family. 


\section{REFERENCES}

Ackerman, D. J., \& Barnett, W. S. (2005). Prepared for Kindergarten: What does "readiness" mean? New Brunswick, NJ: National Institute for Early Education and Research, Rutgers University.

Alston, J. A. (2004). The many faces of American schooling: Effective schools research and border crossing in the 21st Century. American Secondary Education, 12(2), 79-93.

Appalachia Educational Laboratory at Edvantia. (December, 2005). A case study of six high-performing schools in Tennessee. Charleston, WV: Edvantia.

Archer, J. (2002). Group cites needy but high performing schools. Education Week, $21(16), 3$.

Bagdi, A., \& Vacca, J. (2006). Supporting early childhood social-emotional well-being: The building blocks for early learning and school success. Early Childhood Education Journal, 33(3), 145-150. doi:10.1007/s10643-005-0038-y

Bandura, A. (1977). Staff efficacy: Toward a uniform theory of behavioral change. Psychological Review, 84, 191-215.

Barth, P. Haycock, K., Jackson, H., Mora, K., Ruiz, P., Robinson, S., \& Wilkins, A. (1999). Dispelling the myth: High poverty schools exceeding expectations. Washington, DC: Education Trust and Council of Chief State School Officers.

Berkley, A. (2009). SPARK: Supporting partnerships to assure ready kids. Retrieved from http://www.wkkf.org

Bisanz, J., Morrison, F. J., \& Dunn, M. (1995). Effects of age and schooling on the acquisition of elementary quantitative skills. Developmental Psychology, 31, 221-236.

Blair, C. (2002). School readiness: integrating cognition and emotion in a neurological conceptualization of children's functioning at school entry. American Psychologist, 57(2), 111-127.

Bohan-Baker, M., \& Little, P. M. D. (2002). The transition to Kindergarten: A review of current research and promising practices to involve families. Boston, MA: Harvard Family Research Project.

Bowman, B. T., Donovan, S., \& Burns, M. S. (2000). Eager to learn: Educating our preschoolers. Washington, DC: National Academy Press.

Boyer, E. (1992). Ready to learn: A mandate for the nation. Princeton, N J: Carnegie Foundation for the Advancement of Teaching. 
Bracey, G. W. (2005). Is your school ready? Principal, 85(1), 40-45.

Bradley, R. H., \& Corwyn, R. F. (2002). Socioeconomic status and child development. Annual Review of Psychology, 53(1), 371-399.

Brock, K. J., \& Groth, C. (2003). Becoming effective: Lessons from one state's reform initiative in schools serving low-income students. Journal of Education for Students Placed at Risk, 8(2), 167-190.

Brookover, W. R., Beady, C., Flood, P., Scheweizer, J., \& Weisenbaker, J. (1979). Schools, social systems and student achievement: Schools can make a difference. New York, NY: Praeger.

Brookover, W. R., \& Lezotte, L. W. (1979). Changes in school characteristics coincident with changes in student achievement. East Lansing, MI: Michigan State University, College of Education.

Brookover, W. R., \& Schneider, J. M. (1975). Academic environments and elementary school achievement. Journal of Research and Development in Education, 9(1), 82-91.

Brown, L., Lynch, S., \& Franke, T. (2007). First five Tulare County: Ready schools evaluation in Tulare County. Los Angeles, CA: UCLA Center for Healthier Children, Families and Communities.

Burke, J. F., \& Burke, W. M. (2005). Student ready schools. Childhood Education, 81(5), 281-286.

Carlton, M. P., \& Winsler, A. (1999). School readiness: The need for a paradigm shift. School Psychology Review, 28(3), 338-352.

Castro, D. C., Bryant, D. M., Peisner-Feinberg, E. S., \& Skinner, M. I. (2004). Parent involvement in Head Start programs: The role of parent, teacher and classroom characteristics. Early Childhood Research Quarterly, 19(3), 413-430.

Choi, S. C. (1977). Test of equality of dependent correlat ions. Biometrika, 64(3), 645-647.

Christie, K. (2004). Virginia's excellent adventure. Phi Delta Kappan, 65(8), 565-567.

Civil Rights Act of 1964. Pub. L. 88-352. 78 Stat. 241. (1964).

Cohen, M. (1983). Effective Schools: A synthesis and state policy implications. Background paper. Washington, DC: Education Commission of the States.

Cole-Henderson, B. (2000). Organizational characteristics of schools that successfully serve low-income urban African American students. Journal of Education for Students Placed At Risk, 5(1), 77-91. 
Coleman, J. (1966). Equality of educational opportunity. Washington, DC: U.S. Government Printing Office.

Cook, B. G., Gerber, M. M., \& Semmel, M. I. (1997). Are effective schools reform effective for all students? The implications of joint outcome production for school reform. Exceptionality, 7(2), 77-95.

Copple, C., \& Bredecamp, S. (2009). Developmentally appropriate practice in early childhood programs serving children birth through Age 8. Washington, DC: National Association for the Education of Young Children.

Costenbader, V., Rohrer, A., \& Difonzo, N. (2000). A survey of Kindergarten screening: Current practice. Psychology in Schools, 37(4), 323-333.

Creemers, R. (1996). The school effectiveness knowledge base. In D. Reynolds, R. Bollen, B. Creemers, D. Hopkins, L. Stoll, \& N. Lagerweij (Eds.). Making good schools: Linking school effectiveness and school improvement (pp. 36-58). London, UK: Routledge.

Crone, D. A., \& Whitehurst, G. J. (1999). Age and schooling effects on emergent literacy and early reading skills. Journal of Educational Psychology, 91(4), 604-614.

Curtis, P. A., \& Simons, K. A. (2008). Pathways to ready schools. Child Adolescent Social Work, 25(13), 171-183. doi:10.1007/s10560-008-0119-z

Daily, S., Burkhauser, M., \& Halle, T. (2010). A review of school readiness practices in the states: Early learning guidelines and assessments. Early Childhood Highlights, $1(3), 1-12$.

Daniels, D. H. (2011). Supporting early school success. Educational Leadership, $66(7), 18-22$.

Darling-Hammond, L. (2010). The flat world and education: How America's commitment to equity will determine our future. New York, NY: Teachers College Press.

Darling-Hammond, L., Wise, A. E., Klein, S. P. (1999). A license to teach: Raising standards for teaching. San Francisco, CA: Josey-Bass.

Datnow, A., \& Stringfield, S. (2000). Working for reliable school reform. Journal of Education for Students Placed At Risk, 5(1 \& 2), 183-204.

Dearing, E., Krieder, H., Simpkins, S., \& Weiss, H. (2008). Family involvement in lowincome children's literacy: Longitudinal associations within and between families. Journal of Educational Psychology, 98(4), 653-664.

Denton, K., \& West, J. (2002). Children's reading and mathematics achievement in Kindergarten and first grade. Education Statistics Quarterly, 44(1), 1-78. 
Duncan, G. J., Dowsett, C. J., Claessens, A., Magnuson, K., Huston, A. C., Klebanov, P., Japel, C. (2007). School readiness and later achievement. Developmental Psychology, 43(6), 1428-1446. doi:10.1037/0012-1649.43.6.1428

Duncan, G. J., Morris, P. A., Rodrigues, C. (2011). Does money really matter? Estimation impacts of family income on young children's achievement with data from random assigned experiments. Developmental Psychology, 47(5), 1263-1278.

Early, D. M., Pianta, R. C., Taylor, L. C., \& Cox, M. J. (2001). Transition practices: Findings from a national survey. Early Childhood Education Journal, 28(3), 199-206.

Edmonds, R. R. (1979 a). Effective schools for the urban poor. Educational Leadership, $37(1), 15-24$.

Edmonds, R. R. (1979 b). Some schools work and more can. Social Policy, 12(2), 28-32.

Edmonds, R. R. (1981). Making public schools effective. Social Policy, 12(2), 56-60.

Education Trust. (1999). Dispelling the myth: High poverty schools exceeding expectations. Washington, DC: Author.

Enwisle, D. R., Alexander, K. L., \& Olson, L. S. (2005). First grade and educational attainment by Age 22: A new story. American Journal of Sociology, 110(6), $1458-1502$

Epstein, A. S., Schweinhart, L. J., DeBruin-Parecki, A., \& Robin, K. B. (2004). Preschool assessment: A guide to developing a balanced approach. Preschool Policy Matters. New Brunswick, NJ: National Institute for Early Education Research.

Eubanks, E. E., \& Levine, D. U. (1984). Effective inner city elementary schools. Social Policy, 15(2), 4-29.Evans, G. W. (2004). The environment of childhood poverty. American Psychologist, 59(2), 77-92.

Evans, G. W. (2004). The environment of childhood poverty. American Psychologist, 59(2), 77-92.

Fantuzzo, J., Perlman, S., Sproul, F., Minney, A., Perry, M. (2012). Making visible teacher reports of their teaching experiences: The early childhood teacher. Psychology in the Schools, 49(2), 194-205.

Fantuzzo, J., Perry, M. A., \& McDermott, P. (2004). Preschool approaches to learning and their relationships to other classroom competencies for low-income children. School Psychology Quarterly, 19(3), 212-230.

Farkas, G., \& Beron, K. (2004). The detailed age trajectory of oral vocabulary knowledge: Difference by class and race. Social Science Research, 33(3), 
464-497.

Fay, M. P., \& Proschan, M. A. (2010). Wilcoxon-Mann-Whitney or T-test? Statistics Surveys, 4, 1-39.

Ferri, E., \& Stemberg, R. J. (1998). The development of mental abilities and styles. In W. Damon (Ed.), Handbook of child psychology: Child psychology and practice (5th ed.), 2, 899-946.

Frank Porter Graham Child Development Institute. (2011). The first school project. Chapel Hill, NC: University of North Carolina at Chapel Hill.

Goals 2000: Educate America Act. Pub. L. 103-227. 108 Stat. (1994).

Golan, S., \& Wechler, M. (2008). Early implementation of ready schools Miami: Findings of the first year of implementation (SRI Project 18246). Menlo Park, CA: SRI International.

Gordon, A. (2002). SurveyMonkey. com-Web-Based Survey and Evaluation System: http://www. SurveyMonkey.com. The Internet and Higher Education, 5(1), $83-87$.

Graue, E., Clements, M. A., Reynolds, A. J., \& Niles, M. D. (2004). More than teacher directed or child initiated: Preschool curriculum type, parent involvement, and children's outcomes in the child-parent centers. Education Policy Analysis Archives, 12(72), 1-37.

Graue, M. E. (1993). Ready for what? Constructing meanings of readiness for Kindergarten. Albany, NY: State University of New York Press.

Greer, T., \& Lockman, J. J. (1998). Using writing instruments: Invariances in young children and adults. Child Development, 59(1), 26-37.

Grissom, J. B. (2004). Age and achievement. Education Policy Analysis Archives, 12(49), $1-42$.

Guo, Y., Connor, M. C., Yang, Y., Roehrig, A. D., \& Morrison, F. S. (2012). The effects of teacher qualifications, teacher self-efficacy, and classroom practices on fifth graders' literacy outcomes. Elementary School Journal, 113(1), 3-24.

Guskey, T. R., \& Passaro, P. D. (1994). Teacher efficacy: A study of construct dimensions. American Educational Research Journal, 31, 627-643.

Hair, E., Halle, T., Terry-Humen, E., Lavelle, B., \& Calkins, J. (2006). Children's school readiness in the ECLS-K: Predictions to academic, health, and social outcomes in first grade. Early Childhood Research Quarterly, 21(4), 431-454. doi:10.1016/j.ecresq.2006.09.005 
Halle, T., Reidy, M., Moorehouse, M., Zaslow, M., Walsh, C., Calkins, J., Margie, N. G., $\&$ Dent, A. (2008). Progress in the development of indicators of school readiness. In B. Brown (Ed.) Key indicators of child and youth well-being: Completing the picture (pp. 65-102). New York, NY: Erlbaum.

Hallinger, P., \& Heck, R. (1996). Reassessing the principal's role in school effectiveness: A review of empirical research 1980-1995. Educational Administration Quarterly, 32(1), 5-44.

Hamre, B. K., \& Pianta, R. C. (2001). Early teacher-child relationships and the trajectory of children's school outcomes through eighth grade. Child Development, 76(2), 625-638.

Hart, B., \& Risley, T. (1995). Meaningful differences in the everyday experience of young American children. Baltimore, MD: Paul H. Brookes.

Hawley, W. D., Rosenholt, S., Goodstein, H. J., \& Hasselbring, T. (1984). Good schools: What research says about improving student achievement. Peabody Journal of Education, 61(4), 1-178.

Haycock, K., Barth, P, Jackson, H., Mora, K., Ruiz, P., Robinson, S., \& Wilkins, A. (1999). Dispelling the myth: High poverty schools exceeding expectations. Washington, DC: Education Trust.

Hemmeter, M. L., Townley, K. F., \& Wilson, S. (1997). Third party evaluation of the Kentucky preschool programs: 1996-1997 final report. Lexington, KY: University of Kentucky.

Hernandez, D. J. (2011). Double jeopardy: How third-grade reading skills and poverty influence high school graduation. Baltimore, MD: The Annie E. Casey Foundation.

Hersh, R. H., Carnine, D., Gall, M., Stockard, J, Carmack, M. A., \& Gannon, P. (1981). The management of education professionals in instructionally effective schools: Toward a research agenda. Eugene, OR: Center for Educational Policy and Management, University of Oregon.

High, P. C. (2008). School readiness. Pediatrics, 12(4), 1008-1015. doi:10.1542/ peds.208-0079J

High/Scope Educational Research Foundation. (2006a). The Ready School Assessment: Administration manual. Ypsilanti, MI: High/Scope Press.

High/Scope Educational Research Foundation. (2006b). The Ready School Assessment. Making every school a place where every child can learn. Ypsilanti, MI: High/Scope Press. 
Howes, C., Burchinal, M., Early, D., Pianta, P., Bryant, D., Clifford, R. (2008). Ready to learn? Children's pre-academic achievement in pre-Kindergarten programs. Early Childhood Research Quarterly, 23(1), 27-50.

Hoyt, W. (2008). An evaluation of the Kentucky Education Reform Act. Center for Business and Economic Research. Lexington, KY: University of Kentucky. Retrieved from http://cber.uky.edu

Huang, F. L., Invernizzi, M. A., \& Drake, E. A. (2011). The differential effects of preschool: Evidence from Virginia. Early Childhood Research Quarterly, V(i). doi:10.1016/j.ecresq.2011.03.006

Isaacs, J. B. (2012). Starting school at a disadvantage: The school readiness of poor children. Center on Children and Families. Washington, DC: Brookings Institution.

Isaacs, J. B., \& Magnuson, K. (2011). Income and education as predictors of children's school readiness. Washington, DC: The Brookings Institution.

Jones, N. P. (2005). Big jobs: Planning for competence. Young Children, 60(2), 86-93.

Kagan, S. L. (2009). American childhood education: Preventing or perpetuating inequity? Equity matters. Research Review No. 3. New York, NY: Columbia University.

Kagan, S. L., Moore, E., \& Bredecamp, S. (Eds.). (1995). Reconsidering children's early development and learning: Toward common views and vocabulary. National Education Goals Panel, Goal 1 Technical Planning Group. Washington, DC: U.S. Government Printing Office.

Kannapel, P. J., \& Clements, S. K. (2005). Inside the black box of high-performing highpoverty schools. A report from the Prichard Committee for Academic Excellence. Lexington, KY.

Katz, L., \& Chard, S. C. (2000). Engagiing children's minds: The project approach (2nd ed.). Norwood, NJ: Ablex.

Keilty, B. LaRocco, D. J., \& Casell, F. B. (2009). Early interventionists' reports of authentic assessment methods through focus group research. Topics in Early Childhood Special Education, 28(4), 244-256.

Kentucky Department of Education. (2010). District readiness survey. Frankfort, KY: Author.

Kentucky Department of Education. (2012a). Kentucky education facts. Frankfort, KY: Author. 
Kentucky Department of Education. (2012b). Proficiency delivery plan. Frankfort, KY: Author. Retrieved from http://education.ky.gov

Kentucky Department of Education. (2014). Every child: Proficient and prepared for success. Retrieved from http://education.ky.gov/schools/Pages/default/aspx

Kentucky Education Reform Act of 1990. KERA: House Bill 940. Frankfort, KY: Kentucky Legislature.

Kentucky Early Childhood Task Force. (2010). Report to the governor. Executive Order 2009-2230. Frankfort, KY.

Kentucky Governor's Office of Early Childhood. (2014). Half of incoming Kindergarten students are ready for school. Frankfort, KY: Author. Retrieved from kidsnow.ky.gov/school\%20readiness/pages/2013

Klitgaard, R. E., \& Hall, G. R. (1974). Are there unusually effective schools? Journal of Human Resources, 74, 90-106.

Konold, T. R., \& Pianta, R. C. (2005). Empirically derived, person-orientated patterns of school readiness in typically-developing children: Description and prediction to first-grade attainment. Applied Developmental Science, 9(4), 174-187. doi: $1207 / \mathrm{s} 1532$

LaParo, K. M., \& Pianta, R. C. (2000). Predicting children's competence in the early years: A meta-analytic review. Review of Educational Research, 70(4), 443-484.

Lara-Cinisomo, S., Fuligni, A. S., Ritchie, S., Howes, C., \& Karoly, L. (2008). Getting ready for school: An examination of early childhood educators' belief systems. Early Childhood Education Journal, 35, 343-349. doi:007/s/10643-007-0215-2

Lawse, C. H. (1975). A quantitative approach to content validity. Personnel Psychology, $28,563-575$.

Leahy, S., Lyon, C., Thompson, M., \& William, D. (2005). Classroom assessment: minute by minute, day by day. Educational Leadership, 63(3), 19-24.

Lee, V., \& Burkham, D. (2002). Inequality at the starting gate: Social background differences in achievement as children begin school. Washington, DC: Economic Policy Institute.

Leithwood, K. L., Harris, A., \& Hopkins, D. (2008). Seven strong claims about successful school leadership. School Leadership and Management, 28(1), 27-42.

Levine, D. U., \& Lezotte, L. W. (1990). Unusually effective schools. Madison, WI: University of Wisconsin, Madison National Center for Effective Schools Research and Development. 
Levine, D. U., \& Stark, J. (1982). Instructional and organizational arrangements that improve achievement in inner-city schools. Educational Leadership, 40(3), 41-46.

Levine, M. (1986). Excellence in education: Lessons from America's best-run companies and schools. Peabody Journal of Education, 63(2), 150-186.

Lewitt, E. M., \& Baker, L. S. (1995). School readiness. Critical Issues for Children and Youth, 5(2), 128-139.

Lezotte, L. W. (1992). Learn from effective schools. Social Policy, 22(3), 34-36.

Lezotte, L. W., \& Bancroft, (1985). Growing use of the effective schools model for school improvement. Educational Leadership, 42(6), 23-27.

Lin, H-L, Lawrence, F., \& Gorrell, J. (2003). Kindergarten teachers' views of children's readiness for school. Early Childhood Research Quarterly, 18(2), 225-237.

Linares, L. O., Rosbruch, N., Stern, M. B., Edwards, M. E., Walker, G., Abikoff, H. B., \& Alvir, J. M. J., (2005). Developing cognitive-social-emotional competencies enhance academic learning. Psychology in the Schools, 42(4), 405-417.

Mann, H. B., \& Whitney, D. R. (1947). On a test of whether one of two random variables is stochastically larger than the other. Annals of Mathematics Statistics, 18(1), 50-80.

Manset, G., St. John, E. P., Simmons, A., Gordon, D., Musoba, G. D., Klingman, K., et al. (2000). Wisconsin's high performing/high poverty schools. Napierville, IL: North Central Regional Laboratory.

Maryland Department of Education. (2011). Getting ready: The 2010-2011 Maryland school readiness report. Baltimore, MD: Author.

Maryland Department of Education. (2012). Getting ready: The 2011-2012 Maryland school readiness report. Baltimore, MD: Author.

Masumoto, M., \& Brown-Welty, S. (2009). Case study of leadership practice and schoolcommunity interrelationships in high-performing, high-poverty rural California high schools. Journal of Research in Rural Education, 24(1), 1-18.

Maxwell, K. L., \& Clifford, R. M. (2004, January). School readiness assessment: Research in review. Beyond the Journal, Young Children on the Web, 1-10.

McClelland, M. M., Morrison, F. J., \& Holmes, D. L. (2000). Children at risk for early academic problems: The role of learning related social skills. Early Childhood Research Quarterly, 15(3), 307-329.

McCormick, K. M. (2003). Characteristics and attributes of primary programs and practices. Lexington, KY: College of Education, University of Kentucky. 
McDermott, P. A., Mordell, M., \& Stolzfus, J. C. (2001). The organization of student performance in American schools: Discipline, motivation, verbal learning, and nonverbal learning. Journal of Educational Psychology, 93(1), 65-76.

McGee, G. W. (2004). Closing Illinois' achievement: Lessons from the "Golden Spike" high poverty high performing schools. Paper presented at the annual meeting of the American Education Research Association, Chicago, IL, April 21-25, 2003.

McGuinn, P. (2011). Stimulating reform: Race to the top competitive grants and the Obama education agenda. Educational Policy, 20(5), 1-24. doi: $10.1177 / 0895904811425911$

Meisels, S. J. (1999, April). A comprehensive conceptualization of school readiness. Paper presented at the biennial meeting of the Society for Research in Child Development, Albuquerque, NM.

National Association for the Education of Young Children. (2009). Were we stand on school readiness. Washington, DC: Author.

National Center for Research in Early Childhood Education. (2010). Increasing knowledge in early childhood. NCRECE in Focus, 3(4).

National Center for Education Statistics. (2009). America's kindergartners. Washington, DC: U.S. Department of Education.

National Education Goals Panel. (1990). March toward excellence. Retrieved from http://www.govinfo. library.unt.edu/.

No Child Left Behind Act of 2002. Pub. L. No. 107-110, 107th U.S. Congress.

North Carolina Department of Education. (2001). North Carolina ready schools initiative: All schools ready for all children. Raleigh, NC: North Carolina Department of Education.

Nunnelly, J., \& Bernstein, I. (1993). Psychometric theory. New York, NY: McGraw Hill.

Office of Head Start. (2010). Program description. Washington, DC: U.S. Department of Health and Human Services, Administration for Children and Families.

Pennsylvania Department of Education, Pennsylvania Governor's Forum. (2008). Linking ready kids to ready schools: A view from Pennsylvania. Harrisburg, PA: Author.

Perroncel, C. B. (2000). Getting kids ready for school in rural America. Charleston, WV: AEL.

Perez, H. (2005). Readiness for school entry community survey. Public Health, 119(4), 283-289. 
Pianta, R. C., \& Kraft-Sayre, M. (2003). Successful transitions: Your guide to connecting children, families, and schools. Baltimore, MD: Paul Brookes.

Piotrkowski, C. S. (2004). A community-based approach to school readiness in Head Start. In E. Zigler \& S. J. Styfco (Eds.), The Head Start Debates (pp.129-142). Baltimore, MD: Paul H. Brookes.

Piotrkowski, C. S., Botsko, M., \& Mattews, E. (2001). Parents' and teachers' beliefs about children's school readiness in a high-need community. Early Childhood Research Quarterly, 15(4), 537-558.

Protheroe, N. (2006). Readiness for Kindergarten: What schools can do. Principal, 66(1), $32-36$.

Purkey, S. C., \& Smith. M. S. (1983). Effective schools: A review. The Elementary School Journal, 83(4), 426-452.

Raver, C. C. (2002). Emotions matter: Making the case for the role of young children's emotional development for early school readiness. Social Policy Report, 16(3).

Raver, C. C., Aber, J. L., \& Gershoff, E. T. (2007). Testing equivalence of mediating models of income, parenting, and school readiness for white, black, and Hispanic children in a national sample. Child Development, 78(1), 96-115.

Raver, C. C., \& Zigler, E. F. (1997). New perspectives on Head Start competence: An untapped dimension in evaluating Head Start success. Early Childhood Research Quarterly, 12(4), 363-385.

Ravitch, D. (1984). A good school. The American Scholar, 53(4), 481-493.

Reynolds, A. J., Temple, J. A., Robertson, D. L., \& Mann, E. A. (2002). Age 21 costbenefit analysis of the Title 1 Chicago child-parent centers. Education Evaluation and Policy Analysis, 24(4), 267-303. doi:10.3102/0162373702004267

Ritchie, S., Maxwell, K., \& Clifford, R. M. (2009). What is first school? Issues in Pre-K3rd Grade Education. Issue Brief No 1. Chapel Hill, NC: Frank Porter Graham Child Development Institute.

Rimm-Kaufman, S. E., Pianta, R. C., \& Cox, M. J. (2000). Teachers' judgments of problems in the transition to Kindergarten. Early Childhood Research Quarterly, $15,147-166$.

Rouse, C., Brooks-Gunn, J., \& McLanahan, S. (2005). Schoool readiness: Closing racial and ethnic gaps - Introducing the issue. The Future of Children, 15(1), 5-13.

Sameroff, A. J., \& Fiese, B. H. (2000). Models of development and developmental risk. In C. H.Zeanah, Jr. (Ed.), Handbook of Infant Mental Health (pp. 3-19). New York, NY: Guilford Press. 
Sallant, P., \& Dillman, D. A. (1994). How to conduct your own survey. New York, NY: John Wiley and Sons.

Saluja, G., Scott-Little, C., \& Clifford, R. M. (2000). Readiness for school: A survey of state policies and definitions. Early Childhood Research and Practice, 16(1-2). Retrieved from http://ecrp.uiuc.edu/v2n2/saluja.html

Schweinhart, L. J., Montie, J., Xaing, Z., Barnett, W. S., Belfield, C. R., \& Nores, M. (2005). Lifetime effects: The High/ Scope Perry Preschool study through Age 40. Ypsilanti, MI: High/Scope Press.

Scott-Little, C., Kagan, S. L., \& Frelow, V. S. (2006). Conceptualization of readiness and the content of early learning standards: The intersection of policy and research? Early Childhood Research Quarterly, 21(2), 153-173.

Shannon, G. S., \& Bylsma, P. (2007). The nine characteristics of high-performing schools: A research-based resource for schools and districts to assist with improving student learning. (2nd ed.). Olympia, WA: Office of the Superintendent of Public Instruction.

Sharif, I., Ozuah, P., \& Dinkevich, E. (2003). Impact of a brief literacy intervention on urban preschoolers. Early Childhood Education Journal, 30(3), 177-180.

Shepard, L. A., Kagan, S. L., \& Wurtz, E. (1998). Principles and recommendations for early childhood assessments. Washington, DC: National Education Goals Panel.

Shonkoff, J. P., \& Phillips, D. A. (Eds). (2000). From neurons to neighborhoods: The science of early childhood development. Washington, DC: National Academy Press.

Shore, R. (1998). Ready schools: A report of the Goal 1 Ready Resource Group. Washington, DC: National Education Goals Panel.

Snow, C. E., Burns, M. S., \& Griffin, P. (Eds.). (1998). Preventing reading difficulties in young children. Washington, DC: National Research Council and National Academy Press.

Starch, S. A., \& Whitehurst, G. J. (2002). Oral language and code-related precursors to reading: Evidence from a longitudinal structural model. Developmental Psychology, 38, 934-937.

Stiggins, R. (2008, April). Assessment for learning, the achievement gap and truly effective schools. Presentation at the Assessment for Learning Conference, Lexington, KY.

Stipek, D. J., \& Byler, P. (2001). Academic achievement and social behaviors associated with age of entry into Kindergarten. Applied Developmental Psychology, 22, $175-189$. 
Stipek, D. J., \& Ryan, R. H. (1997). Economically disadvantaged preschoolers: Ready to learn but further to go. Developmental Psychology, 33, 711-723.

Strickland, D. S. (2006). Language and literacy in Kindergarten. In D. F. Gullo (Ed.), K today: Teaching and learning in the Kindergarten year (pp. 73-84). Washington, DC: National Association for the Education of Young Children.

Teddlie, C., \& Stringfield, S. (1989). Schools do make a difference: Lessons learned from a 10-year study of school effects. New York, NY: Teachers College Press.

U.S. Department of Education. (2002a). Early childhood conference of the states. St. Louis, MO: Author.

U.S. Department of Education. (2002b). Good start, grow smart: The Bush administration's early childhood initiative. Retrieved from http://georgebushwhitehouse.archives.gov

Vakil, S., Freeman, R., \& Swim, T. J. (2003). The Reggio Emilia approach and inclusive early childhood programs. Early Childhood Education Journal, 30(3), 177-180.

Warren, J. F. (2008). A comparison of faculty and administrator perceptions of the merger of Kentucky's community colleges and vocational/technical institutes (Doctoral dissertation). Retrieved from http://digital.library.louisville.edu

Wertheimen, R., \& Croan, T. (2003). Attending Kindergarten and already behind: A statistical portrait of vulnerable young children. Washington, DC: Child Trends.

Wesley, P. W., \& Buysse, V. (2003). Making meaning of school readiness in schools and communities. Early Childhood Research Quarterly, 18(3), 351-375.

West, J., Denton, K., \& Germino-Hausken, E. (2000). America's kindergartners: Findings from the early childhood longitudinal study, Kindergarten class of 1998-1999. NCES 2001-070R. Washington, DC: U.S. Department of Education National Center for Education Statistics.

West, J., Hausken, E. G., \& Collins, M. (1993). Readiness for Kindergarten: Parents and teacher beliefs. Washington, DC: U.S. Department of Education, Office of Research and Improvement. (NCES 93257)

Whitehurst, C. J., \& Lonigan, C. J. (1998). Child development and emergent literacy. Child Development, 69, 848-872.

Wilder Research for the Minnesota Initiative Foundations. (2007). Minnesota early childhood initiative: Building nurturing communities of thriving children. St. Paul, MN: Author.

Winsler, A., Tran, H., Hartman, S. C., Madigan, A. L., Manfra, C., Bleiker, C. (2008). School readiness gains made by ethnically diverse children in poverty attending 
center-based childcare and public school prekindergarten programs. Early childhood Research Quarterly, 23(3), 314-329.

Winters, K., Williams, D., Kelly, D., McGaha, V., Stine, K., Thayer, D. (2009). SB1 (BR803). An act relating to student assessment. Frankfort, KY: Kentucky Legislation. Retrieved from http://www.lrc.ky.gov/record/09rs/sb1.htm

Wright, C., Diener, M., \& Kay, S. C. (2000). School readiness of low-income children at risk for school failure. Journal of Children in Poverty, 6(2), 99-117.

Yen, C., Konold, T. R., \& McDermott, P. A. (2004). Does learning behavior augment cognitive ability as an indicator of academic achievement? Journal of School Psychology, 42, 157-169.

Zigler, E., Gilliam, W. S., \& Jones, S. M. (2006). A vision for universal preschool education. New York, NY: Cambridge University Press.

Zuckerman, B., \& Halfon, N. (2003). School readiness: An idea whose time has arrived. Pediatrics, 111(6), 1433-1437. 
Appendix A

\section{READY CHILD AND READY SCHOOL SURVEY}

I am conducting a study about child and school readiness and would like to obtain your opinion about success indicators that promote child readiness for school and success indicators that promote school readiness for children. Completing the survey is voluntary, although it may help to identify ready child and ready school indicators that can lead to successful students and schools. Your input is very important.

Each of the items in this survey relates to either child readiness (Section I) or school readiness (Sections II and III). The survey will take about 15 minutes to complete. To ensure your responses remain confidential, they will be combined with other responses and reported as a group to those who are interested in this topic such as state education agencies, local education agencies, schools, universities, and the early childhood community.

Please complete the following two (2) questions about yourself then complete the survey. Again, all responses will remain confidential. Thank you for your participation. Annette Bridges

1. Your primary role? (check one): _ Principal __ Kindergarten Teacher ___ Preschool/Head Start Teacher

2. How many years have you been in that role at your current school? years 


\section{Section I: Ready Child Indicators}

Although all of the ready child indicators are important, please use your best effort to RANK the following indicators from 1 (most important) to 5 (least important). A number can be used only once.

Approaches to Learning - motivation, attention and persistence in tasks, attitude toward learning, problem solving

Health and Physical Well-Being — health status, growth, physical abilities, gross and fine motor skills Language and Communication-listening, speaking, vocabulary, print awareness Social and Emotional Development—interacts with others, self-regulates, selfperception, understands needs of others, expresses needs and thoughts Cognition and General Knowledge - thinking, reasoning, concepts of mathematics, reading and science

If you had the power to choose ONE thing you would want for every child entering school (Kindergarten) what would that be? 


\section{Section II: Ready School Indicators}

Although all of the ready school indicators are important, please use your best effort to RANK the following indicators from 1 (most important) to 6 (least important). A number can be used only once.

Curriculum - addresses core content in a variety of ways; is engaging and culturally responsive and includes additional supports as needed

Families - have opportunities for on-going, two-way communication; engagement in the educational process and decision-making about activities they help to develop Teachers - make intentional instructional decisions that ensure optimal success; promote teacher-child and child-child interactions; balance activities and strategies (e.g. small/large group; teacher-guided/child initiated)

Assessment - is continuous; meaningful and authentic; matched to children's development; and is used to drive instruction Leadership - communicates a clear vision for the school that is committed to the success of every child; intentionally prepares for incoming students Transition - written plan that includes on-going communication and a formal process between school and early care and education programs (e.g. Head Start, child care centers)

If you could change your school in any way, what ONE thing would you change to make your school more successful? 
Section III: Level of Implementation of Ready School Indicators

Check the box that best describes your opinion about the frequency of implementation of Ready School indicators in YOUR SCHOOL. "NA" means you have no basis to determine a response. PLEASE COMPLETE ALL 6 areas.

\begin{tabular}{|c|c|c|c|c|c|c|}
\hline $\begin{array}{l}\text { 1. The curriculum used at my school } \\
\text { is... }\end{array}$ & $\begin{array}{c}\text { NA } \\
\text { No } \\
\text { Basis }\end{array}$ & $\begin{array}{c}\text { Never } \\
0 \\
0\end{array}$ & $\begin{array}{l}\text { Rarely } \\
\left(\begin{array}{l}1- \\
33 \%) \\
1\end{array}\right.\end{array}$ & $\begin{array}{l}\text { Sometimes } \\
(34-66 \%) \\
2\end{array}$ & $\begin{array}{l}\text { Often } \\
(67- \\
99 \%) \\
3\end{array}$ & $\begin{array}{l}\text { Always } \\
(100 \%) \\
4\end{array}$ \\
\hline $\begin{array}{l}\text { a. Comprehensive and aligned to } \\
\text { common core standards }\end{array}$ & & & & & & \\
\hline $\begin{array}{l}\text { b. Developmentally appropriate } \\
\text { and addresses individual } \\
\text { learning targets }\end{array}$ & & & & & & \\
\hline $\begin{array}{l}\text { c. Relevant and includes } \\
\text { meaningful projects, } \\
\text { experiences and activities }\end{array}$ & & & & & & \\
\hline d. Integrated across content areas & & & & & & \\
\hline $\begin{array}{l}\text { e. Culturally and individually } \\
\text { responsive }\end{array}$ & & & & & & \\
\hline 2. Families at my school... & $\begin{array}{c}\text { NA } \\
\text { No } \\
\text { Basis }\end{array}$ & $\begin{array}{c}\text { Never } \\
0 \\
0\end{array}$ & $\begin{array}{c}\text { Rarely } \\
(1- \\
33 \%) \\
1\end{array}$ & $\begin{array}{c}\text { Sometimes } \\
(34-66 \%) \\
2\end{array}$ & $\begin{array}{l}\text { Often } \\
(67- \\
\mathbf{9 9 \% )} \\
3\end{array}$ & $\begin{array}{l}\text { Always } \\
(100 \%) \\
4\end{array}$ \\
\hline $\begin{array}{l}\text { a. Receive a written/formal plan for } \\
\text { family/parent involvement }\end{array}$ & & & & & & \\
\hline $\begin{array}{l}\text { b. Are intentionally engaged in } \\
\text { student learning }\end{array}$ & & & & & & \\
\hline $\begin{array}{l}\text { c. Receive regular communication } \\
\text { and are expected to respond } \\
\text { (communication is designed to } \\
\text { be two-way) }\end{array}$ & & & & & & \\
\hline $\begin{array}{l}\text { d. Are provided opportunities to } \\
\text { plan activities for themselves }\end{array}$ & & & & & & \\
\hline e. Are welcome partners & & & & & & \\
\hline
\end{tabular}




\begin{tabular}{|c|c|c|c|c|c|c|}
\hline 3. Teachers at my school... & $\begin{array}{c}\text { NA } \\
\text { No } \\
\text { Basis }\end{array}$ & $\begin{array}{c}\text { Never } \\
0 \\
0\end{array}$ & $\begin{array}{c}\text { Rarely } \\
(1- \\
33 \%) \\
1\end{array}$ & $\begin{array}{c}\text { Sometimes } \\
(34-66 \%) \\
2\end{array}$ & $\begin{array}{c}\text { Often } \\
(67- \\
99 \%) \\
3\end{array}$ & $\begin{array}{c}\text { Always } \\
(100 \%) \\
4\end{array}$ \\
\hline $\begin{array}{l}\text { a. Provide a safe, healthy and } \\
\text { welcome environment, for every } \\
\text { child }\end{array}$ & & & & & & \\
\hline $\begin{array}{l}\text { b. Create a learning environment } \\
\text { that promotes student initiative, } \\
\text { creativity and questioning }\end{array}$ & & & & & & \\
\hline $\begin{array}{l}\text { c. Value diversity, demonstrated by } \\
\text { curriculum, activities and } \\
\text { materials }\end{array}$ & & & & & & \\
\hline $\begin{array}{l}\text { d. Consider learning needs of each } \\
\text { individual child for instructional } \\
\text { planning }\end{array}$ & & & & & & \\
\hline $\begin{array}{l}\text { e. Know common core standards } \\
\text { and deliver instruction using a } \\
\text { variety of methods, strategies and } \\
\text { materials to address them }\end{array}$ & & & & & & \\
\hline $\begin{array}{l}\text { 4. The assessment process used in } \\
\text { my school is ... }\end{array}$ & $\begin{array}{c}\text { NA } \\
\text { No } \\
\text { Basis }\end{array}$ & $\begin{array}{c}\text { Never } \\
0\end{array}$ & $\begin{array}{c}\begin{array}{c}\text { Rarely } \\
(1- \\
33 \%) \\
1\end{array} \\
1\end{array}$ & $\begin{array}{c}\text { Sometimes } \\
(34-66 \%) \\
2\end{array}$ & $\begin{array}{l}\text { Often } \\
(67- \\
99 \%) \\
3\end{array}$ & $\begin{array}{c}\text { Always } \\
(100 \%) \\
4\end{array}$ \\
\hline 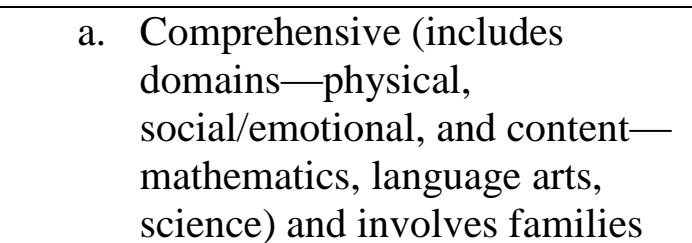 & & & & & & \\
\hline b. Embedded within the curriculum & & & & & & \\
\hline $\begin{array}{ll}\text { c. } & \text { Formative (on-going) and } \\
\text { summative and includes } \\
\text { observations, work samples and } \\
\text { dialogue with students }\end{array}$ & & & & & & \\
\hline $\begin{array}{l}\text { d. Individually tailored to each } \\
\text { student through diagnostic tests } \\
\text { to target individual learning } \\
\text { needs }\end{array}$ & & & & & & \\
\hline
\end{tabular}




\begin{tabular}{|c|c|c|c|c|c|c|}
\hline 5. Leaders at my school... & $\begin{array}{c}\text { NA } \\
\text { No } \\
\text { Basis }\end{array}$ & $\begin{array}{c}\text { Never } \\
0 \\
\end{array}$ & $\begin{array}{c}\text { Rarely } \\
(1- \\
33 \%) \\
1 \\
\end{array}$ & $\begin{array}{c}\begin{array}{c}\text { Sometimes } \\
(34-66 \%)\end{array} \\
2 \\
\end{array}$ & $\begin{array}{c}\text { Often } \\
(67- \\
99 \%) \\
3 \\
\end{array}$ & $\begin{array}{c}\text { Always } \\
(100 \%) \\
4 \\
\end{array}$ \\
\hline $\begin{array}{l}\text { a. Use student data to make } \\
\text { decisions }\end{array}$ & & & & & & \\
\hline b. Include staff in making decisions & & & & & & \\
\hline $\begin{array}{l}\text { c. Demonstrate high expectations } \\
\text { for self, students and teachers }\end{array}$ & & & & & & \\
\hline $\begin{array}{l}\text { d. Intentionally involve families as } \\
\text { partners in learning }\end{array}$ & & & & & & \\
\hline $\begin{array}{l}\text { e. Promote collaboration among } \\
\text { teachers }\end{array}$ & & & & & & \\
\hline $\begin{array}{l}\text { 6. My school has a transition } \\
\text { process that... }\end{array}$ & $\begin{array}{c}\text { NA } \\
\text { No } \\
\text { Basis }\end{array}$ & $\begin{array}{c}\text { Never } \\
0\end{array}$ & $\begin{array}{c}\text { Rarely } \\
(1- \\
33 \%) \\
1\end{array}$ & $\begin{array}{c}\text { Sometimes } \\
(34-66 \%) \\
2\end{array}$ & $\begin{array}{c}\text { Often } \\
(67- \\
99 \%) \\
3\end{array}$ & $\begin{array}{c}\text { Always } \\
(100 \%) \\
4\end{array}$ \\
\hline $\begin{array}{l}\text { a. Facilitates communication } \\
\text { between families of incoming } \\
\text { children and teachers at this } \\
\text { school }\end{array}$ & & & & & & \\
\hline $\begin{array}{l}\text { b. Is implemented through a written } \\
\text { plan }\end{array}$ & & & & & & \\
\hline $\begin{array}{l}\text { c. Promotes on-going } \\
\text { communication with child care, } \\
\text { Head Start and other early } \\
\text { childhood/preschool programs }\end{array}$ & & & & & & \\
\hline $\begin{array}{l}\text { d. Involves all school personnel in a } \\
\text { variety of transition activities }\end{array}$ & & & & & & \\
\hline
\end{tabular}


Appendix B

\section{LIST OF ACRONYMS}

ACT - Appalachia Educational Laboratory

ASA - above the state average

BSA - below the state average

ECLS-K - Early Childhood Longitudinal Study-Kindergarten

ELC - The 2011 Race to the Top Early Learning Challenge Fund

ESM - Effective Schools Movement

ESR - Effective Schools Research

$\mathrm{F} / \mathrm{RL}$ - free or reduced price lunch

$\mathrm{HP} / \mathrm{HP}$ - high-performing and high-poverty schools

K-PREP - 2011-2012 Kentucky Performance Rating for Educational Progress

KDE - Kentucky Department of Education

KERA - Kentucky Education Reform Act of 1990

MMSR - Maryland Model for School Readiness

NAEYC - National Association for the Education of Young Children

NCLB - No Child Left Behind Act of 2001

NEGP - National Education Goals Panel

RSA - Ready Schools Assessment

SEA - State education agencies

SPARK - Supporting Partnerships to Assure Ready Kids 


\section{CURRICULUM VITA}

NAME: $\quad$ Annette W. Bridges

ADDRESS: 4225 Northwestern Parkway

Louisville, KY 40212

DOB: $\quad$ Louisville, Kentucky - February 23, 1953

EDUCATION

\& TRAINING: $\quad$ B.S., Home Economics

Kentucky State University

1971-1975

M.A.T., Elementary Education

Spalding University, Louisville, KY

1986-1989

PROFESSIONAL

EXPERIENCE: Education Consultant

Creative Solutions for Early Learning Programs

2011-Present

Director of Early Childhood, Kentucky Department of Education 2007-2011

Preschool Branch Manager, Kentucky Department of Education 1994-2007

Head Start Parent Coordinator, Jefferson County Public Schools 1984-1994

Adult Education Teacher and Trainer

Jefferson County Public Schools

1979-1990 
AWARDS: Outstanding Adult Education Teacher, Jefferson County Public Schools 1986

Outstanding Staff Award, Jefferson County Public Schools 1990

Kentucky Family Literacy Leadership Award 2001

\section{PROFESSIONAL}

SOCIETIES: Delta Sigma Theta Sorority, Inc.

Forum Fellow, Louisville Courier Journal

National Family Literacy Alliance

NATIONAL MEETING

\section{PRESENTATIONS:}

Improving America's Schools Act: Title I Conference, Washington, DC, October 1996

National Dropout Conference

Tampa, FL, April 1997

National Family Literacy Conference

Orlando, FL, April 2000

National Black Child Development Institute

Los Angeles, CA, November 2004

National Black Child Development Institute

Miami, FL, November 2005

National Association for the Education of Young Children

Chicago, IL, October 2006

National Dropout Conference

Hilton Head Island, SC, April 2009

INVITED PRESENTATIONS: Arkansas Adult Education Conference, Keynote Speaker, September 1998 